\title{
Availability and Quality of Water from the Dakota Aquifer, Northwest lowa
}

\section{United States Geological Survey Water-Supply Paper 2215}

Prepared in cooperation with the lowa Geological Survey

\section{U.S. GEOLOGICAL SURVEY, WRD \\ ROLLA, MISSOURI Library Use Only}





\title{
Availability and Quality of Water from the Dakota Aquifer, Northwest lowa
}

\author{
By M. R. Burkart
}

Prepared in cooperation with the

lowa Geological Survey 


\section{UNITED STATES DEPARTMENT OF THE INTERIOR}

WILLIAM P. CLARK, Secretary

\section{U.S. GEOLOGICAL SURVEY}

Dallas L. Peck, Director

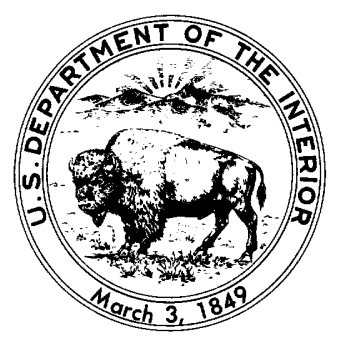

For sale by the Branch of Distribution

U.S. Geological Survey

604 South Pickett Street

Alexandria, VA 22304 


\title{
CONTENTS
}

\author{
Abstract 1 \\ Introduction 1 \\ Scope and purpose of project 1 \\ Scope and objectives of report 1 \\ Acknowledgments 2 \\ General hydrologic concepts 2 \\ Location-numbering system 4 \\ Geologic description of the Dakota aquifer 4 \\ Stratigraphic position 4 \\ Distribution of materials 4 \\ Confining materials 5 \\ Water availability and movement 6 \\ Distribution of potential head and ground-water \\ flow 6 \\ Transmissivity $\mathbf{8}$ \\ Discharge and recharge 8 \\ Estimated potential yield $\mathbf{1 0}$ \\ Water quality10 \\ Major dissolved constituents \\ Radionuclides 11 \\ Quality of water for irrigation 12 \\ Summary and conclusions 13 \\ References cited 14
}

\section{PLATES}

Plates in pocket

1. Map of the top of the Paleozoic or Precambrian age rocks in northwest Iowa

2. Geohydrologic sections through the Dakota aquifer in northwest Iowa

3. Map of the total thickness of sandstone in the Dakota aquifer in northwest Iowa

4. Map of the bedrock surface in northwest Iowa

5. Map of the potentiometric surface and municipal withdrawal from the Dakota aquifer in northwest Iowa, 1979

6. Map of estimated potential yield from the Dakota aquifer in northwest Iowa

7. Map of distribution of dissolved sulfate in water from the Dakota aquifer in northwest Iowa

8. Map of distribution of total dissolved solids in water from the Dakota aquifer in northwest Iowa

\section{FIGURES}

1. Map showing location of the Cretaceous rocks in Iowa and location of the study area 2

2. Chart showing names of geologic units used in this report 4

3. Hydrographs of selected observation wells in the Dakota aquifer 7

4. Irrigation classification of water from the Dakota aquifer 12 
1. Major chemical constituents in water, their effects upon usability and their concentration limits 16

2. Logs of selected test holes 18

3. Water levels in observation wells $\mathbf{5 3}$

4. Summary of pumping tests 61

5. Selected chemical analyses of water from the Dakota aquifer 62

Selected Factors for Converting Inch-Pound Units to the International System

\begin{tabular}{rcl}
\hline Mulitiply inch pound unit & By & To obtain SI unit \\
\hline acre & 4047.0 & square meter \\
foot & 0.3048 & meter \\
foot per day & 0.3048 & meter per day \\
foot squared per day & 0.0929 & meter squared per day \\
gallon & 0.0038 & cubic meter \\
gallon per day & 0.0038 & cubic meter per day \\
gallon per minute & 0.0038 & cubic meter per minute \\
gallon per minute per foot & 0.0124 & meter squared per minute \\
inch & 25.4 & millimeter \\
micromho & 1.0 & microsiemens \\
\hline
\end{tabular}




\section{Availability and Quality of Water from the Dakota Aquifer, Northwest lowa}

\author{
By M. R. Burkart
}

Abstract

The Dakota aquifer in northwest lowa consists of sandstones in the Dakota Formation. It underlies most of the study area and is the most extensive source of ground water in the area. Individual sandstone beds are from less than 10 to more than 150 feet thick. The cumulative thickness of sandstone is more than 200 feet throughout much of the area. The aquifer is confined by overlying Cretaceous limestone and shale, Quaternary glacial deposits and loess. The underlying confining material is shale of the Dakota Formation, undifferentiated Paleozoic age rocks, or Precambrian crystalline rock.

Water flows through the aquifer from the northcentral part of the study area to the east, south and southwest. Recharge is dominantly by infiltration from the land surface through the confining materials. Discharge is to underlying Paleozoic aquifers and to the alluvium and glacial outwash deposits along the Missouri and Big Sioux Rivers in the southwest part of the area. Flow components toward bedrock valleys may reflect discharge to Quaternary sand and gravel deposits in these valleys.

Pumping tests conducted in the study area indicate a narrow range of hydraulic conductivities of the Dakota aquifer, from 37 to 50 feet per day. Consequently, an average hydraulic conductivity of 40 feet per day was used to estimate the potential yield to wells completed in the aquifer. Yields of more than 250 gallons per minute can be expected throughout much of the study area and more than 1,000 gallons per minute could be produced in some areas.

The quality of water from the Dakota is a calcium, magnesium, sulfate type. It is generally suitable for irrigation purposes, based on comparisons of sodium adsorption ratios and electrical conductivities. In some areas the aquifer has water with high salinity hazard that may restrict its use to irrigation of only well-drained types of soil. The concentration of radium-226 and other radionuclides exceeds recommended limits at several sites.

The quality of water pumped from the aquifer may be altered by induced leakage from the underlying aquifers in Paleozoic age rocks if withdrawals reverse the pattern of natural flow from the Dakota into the Paleozoic aquifers. Evidence for such a reversal exists in the area around the city of LeMars.

\section{INTRODUCTION}

\section{Scope and Purpose of Project}

This project was a cooperative project between the Iowa Geological Survey and the United States Geological Survey and included 16 counties in northwestern lowa: Buena Vista, Calhoun, Cherokee, Clay, Dickinson, Emmet, Ida, Lyon, O'Brien, Osceola, Palo Alto, Plymouth, Pocahontas, Sac, Sioux, and Woodbury Counties (figure 1). The project included; (1) a study of the water resources of the Floyd River Basin (Wahl, Meyer, and Karsten, 1981); (2) an evaluation of the regional geologic setting (Ludvigson and Bunker, 1979); and (3) an appraisal of the availability and quality of water from the Dakota aquifer (this report). A report of geologic and pumping test information from the Dakota aquifer is being prepared by the Iowa Geological Survey (Jim Munter, written commun., August 1981).

The purpose of the project was to evaluate the availability and quality of ground-water resources in northwest Iowa. The project began in August 1976, during a drought, in response to an increase in demand for information on sources of irrigation water in northwestern lowa. This demand posed questions about the availability and quality of ground water in the area that could not be answered by using available information.

\section{Scope and Objectives of Report}

This report is a regional appraisal of the availability and chemical quality of water from the Dakota Formation in the project area. Adjacent geologic units are empirically evaluated to determine their influence on the Dakota aquifer flow system. Hydrologic interpretations in this report are based on data from existing wells and test holes drilled for this project, and include lithologic logs, geophysical logs, drillers logs, water-level measurements in observation wells, and chemical analyses of samples of ground water. The objectives of this report are to: (1) define and describe the location, extent, and characteristics 


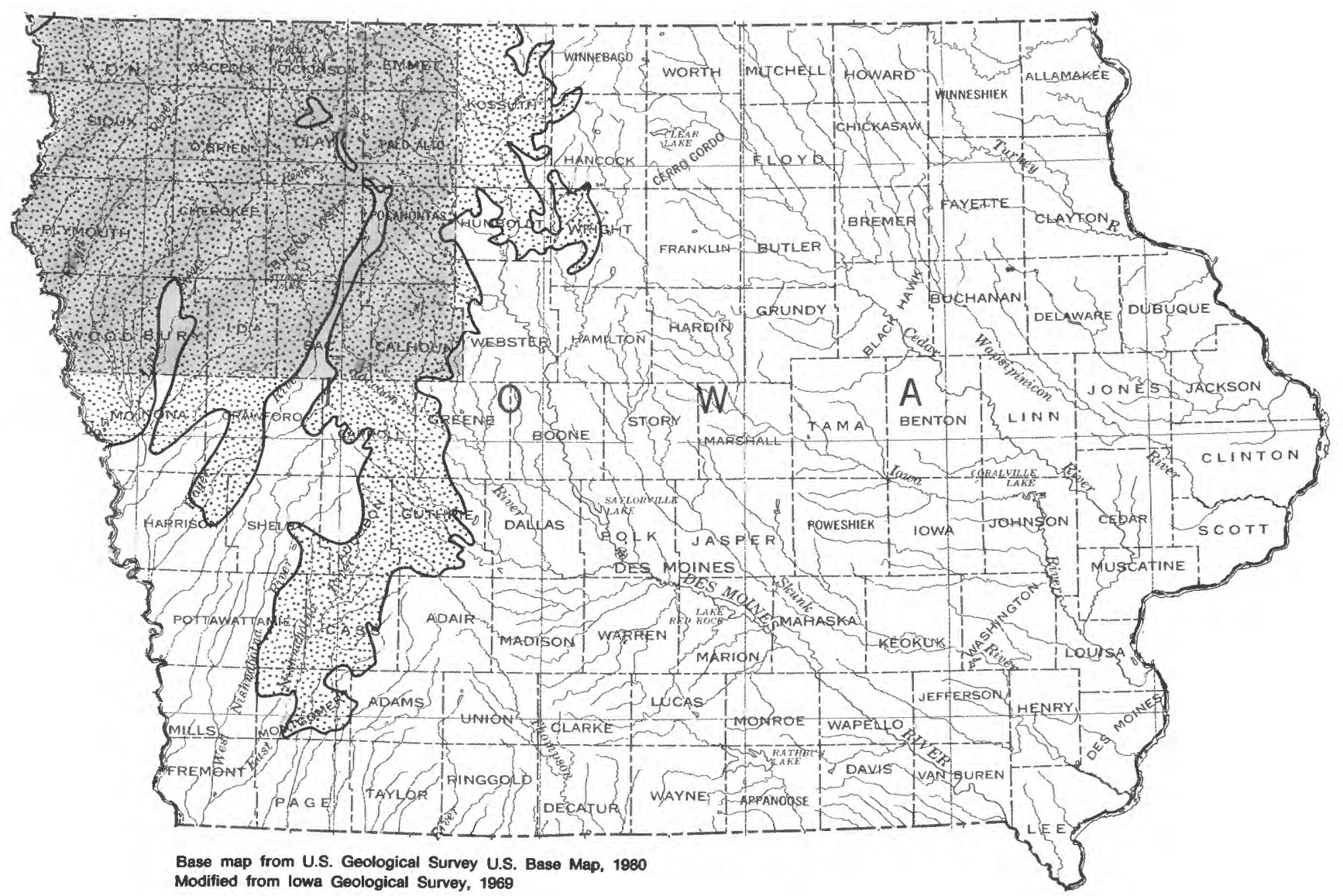

EXPLANATION

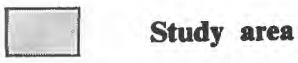

Area underlain by Cretaceous rocks

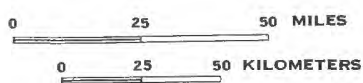

Figure 1. Map showing location of the Cretaceous rocks in lowa and location of the study area.

of the Dakota aquifer; (2) evaluate the occurrence, movement, recharge, and discharge of water in the aquifer; (3) estimate the potential yields to wells penetrating the aquifer; and (4) describe the chemical quality of the water obtained from the aquifer.

\section{Acknowledgments}

Collection of data for this report was made possible by the cooperation of residents of northwest Iowa, municipal water superintendents in the area, and the staffs of the Iowa Department of Environmental Quality and the Iowa Natural Resource Council. Darwin Evans of the Iowa Geological Survey drilled and developed the observation wells and provided most of the sample descriptions of the test holes. Jim Munter of the Iowa Geological Survey contributed to the interpretation of the geohydrology of the area and provided a thorough and helpful review of the final report. Jim Wiegand, Deputy Water Commissioner, Iowa Natural Resources Council, and Don Jorgensen, U.S. Geological Survey, Lawrence, Kansas, also provided thoughtful reviews of the final report.

\section{General Hydrologic Concepts}

All ground water is derived from precipitation. After precipitation falls on the earth's surface, part is returned to the atmosphere by evaporation, part runs off into streams and lakes, and the remainder infiltrates into the 
ground. Some of the water that enters the ground is held by capillary action and evaporates or is used by plants. The water in excess of the near-surface demand of soil and plants infiltrates downward to the water table and ultimately becomes available to wells.

Ground water moves under the influence of gravity and head differences from areas of recharge to areas of discharge. It moves through fractures and small openings among grains of soil and rock. This movement is very slow and may be only a few feet per year. The rate of ground-water movement is governed by the hydraulic conductivity of the material through which it moves and by the hydraulic gradient within or between aquifers.

Hydraulic conductivity is a physical property that expresses a measure of the ability of a material to transmit water. It is determined, in part, by the size and connection of the openings in the material. Gravel, well-sorted sand, poorly cemented sandstones, and fractured rocks generally have a high hydraulic conductivity. These materials form aquifers. Cemented sandstones and fine-grained materials such as silt, clay, and shale usually have a low hydraulic conductivity and restrict ground-water movement. The hydraulic conductivity of an aquifer multiplied by thickness of the aquifer is the transmissivity. The transmissivity of an aquifer can be estimated from data collected by various types of pumping tests conducted in the field.

The hydraulic gradient is a ratio of the hydraulic head difference between two points in a flow system and the distance between the two points. The gradient may be vertical, such as that between two nearly horizontal aquifers, or lateral, as between two points within the same aquifer. The higher the gradient the greater is the potential for flow to the point of lower head, assuming uniform hydraulic conductivity. The most common method of evaluating gradients is to measure water levels in wells that penetrate the aquifer or aquifers of interest. The water levels can be plotted on a map and estimates of direction of movement (water flow) can be made.

The water level in an aquifer, as measured in wells, fluctuates in response to changes in recharge and discharge from the aquifer, usually indicating a change in the amount of water stored in the aquifer. In confined aquifers, changes in atmospheric pressure and in surface load also cause fluctuations in water levels. Aquifers exposed at the land surface are recharged by direct infiltration of precipitaton and snow melt. Aquifers that are confined by thick deposits of fine-grained materials are recharged at very slow rates by leakage from above or below through the fine-grained confining materials. The rate of recharge to an aquifer may increase as water levels in the aquifer are lowered by pumping. This induced recharge is a result of increasing the hydraulic gradient toward the pumped aquifer in the area around a well or wells. However, water levels in the aquifer may decline for several years before sufficient recharge is induced to balance the rate of with- drawal. In some places this balance may never be achieved without curtailment of withdrawals.

Throughout much of the project area potholes, lakes, or rivers are important sources of recharge to the ground-water system. The retention of rainfall, snowmelt, and runoff in potholes and lakes recharges aquifers in which the water level is below the surface water level. In addition, because many of these surface-water features receive water from the local water table during periods of low precipitation, attempts to drain the features will lower the water table in the area. The effects of altering these potholes and lakes may not be seen for many years, but, because seepage from lakes and potholes is a major source of recharge water, the ultimate effect of a reduction in surface-water storage will be a reduction in availability of ground water.

The suitability of water for various uses usually is determined by the kind and amount of dissolved material it contains. The chemical constituents, physical properties and indices most likely to be of concern are iron, sulfate, nitrate, fluoride, chloride, total dissolved solids, hardness, temperature, odor, taste, specific conductance, sodium-adsorption ratio (SAR), and percent sodium. The major chemical constituents, their effects on usability, and the recommended limits are given in table 1 . Additional information regarding drinking-water standards may be found in "Water-Quality Criteria, 1972," published by the U.S. Environmental Protection Agency (National Academy of Sciences-National academy of Engineering, 1973).

In this report, references are made to ground-water types, such as calcium sulfate and calcium bicarbonate types. These types are derived from inspection of the water analyses and represent the predominant cation (sodium, calcium, or magnesium) and anion (sulfate, bicarbonate, or chloride), expressed as milligrams per liter (mg/ L).

The quality of water used for irrigation is an important factor in productivity and in quality of the irrigated crops. Irrigation classifications' were determined from selected water samples from the Dakota aquifer in the project area, using a classification system developed by the U.S. Salinity Laboratory Staff (1954). This classification compares the sodium hazard, as measured by the sodium adsorption ratio, and the salinity hazard, as measured by the conductivity. The conductivity is an electrical property of the water that is approximately proportional to the total dissolved solids content of water. The sodium adsorption ratio is a ratio of the sodium concentration to the calcium and magnesium concentrations measured in equivalents per million.

The type of water suitable for irrigation will depend to some degree upon the type of soil and crop to which the water will be applied. However, water with a medium to very high salinity hazard or sodium hazard may be suitable for only a limited range of irrigation uses. 


\section{Location-Numbering System}

The location-numbering system used in this report is based on the system of land survey used by the U.S. Bureau of Land Management and the Iowa District of the U.S. Geological Survey. The first number indicates the township north of a base line, the second number indicates the range west of the fifth principal meridian, and the third number indicates the section in which the well is located. The letters A, B, C, and D designate the northeast, northwest, southwest, and southeast quarters of a secton or quarters of any smaller square area of a section. The letters following the section number are in order of decreasing areal size from left to right. The first letter designates the 160-acre quarter, the second designates the 40-acre quarter, the third designates the 10 -acre quarter, and the fourth designates the $21 / 2$-acre quarter. For example, well $87-44-15 C B B D$ is in the $S^{1 / 4}$ of the NW $1 / 4$ of the NW $1 / 4$ of the $\mathrm{SW}^{1 / 4}$ of section 15 , in township 87 north and range 44 west. Consecutive sequence numbers are added if more than one well is located in the same tract.

\section{GEOLOGIC DESCRIPTION OF THE DAKOTA AQUIFER}

\section{Stratigraphic Position}

The Dakota aquifer is defined, for this report, as the saturated sandstone that constitutes part of the Dakota Formation. The Dakota Formation comprises the oldest rocks of Cretaceous age recognized in northwest Iowa, and lies unconformably on Paleozoic and Precambrian rocks. The relative position of geologic units with the oldest at the bottom is shown in figure 2 . In the western part of the study area, the Dakota Formation is conformably overlain (from oldest to youngest) by the Graneros Shale, Greenhorn Limestone, and Carlile Shale, all of Cretaceous age. However, throughout more than 80 percent of the project area the Dakota Formation is overlain by Quaternary deposits consisting of glacial till, loess, sand, and gravel.

The top of the Dakota Formation is generally difficult to determine from drill-hole cuttings. The shale in the upper part of the Dakota Formation is similar to the shale that constitutes the overlying Graneros Shale. It is only where the top of the Dakota Formation consists of sandstone that the top can be picked with reasonable certainty. The Dakota Formation is the only Cretaceous formation in Iowa that includes sandstone. Because the Graneros Shale and shale in the upper part of the Dakota Formation are similar, it is not essential to determine the top of the Dakota for hydrologic purposes where it is a shale.

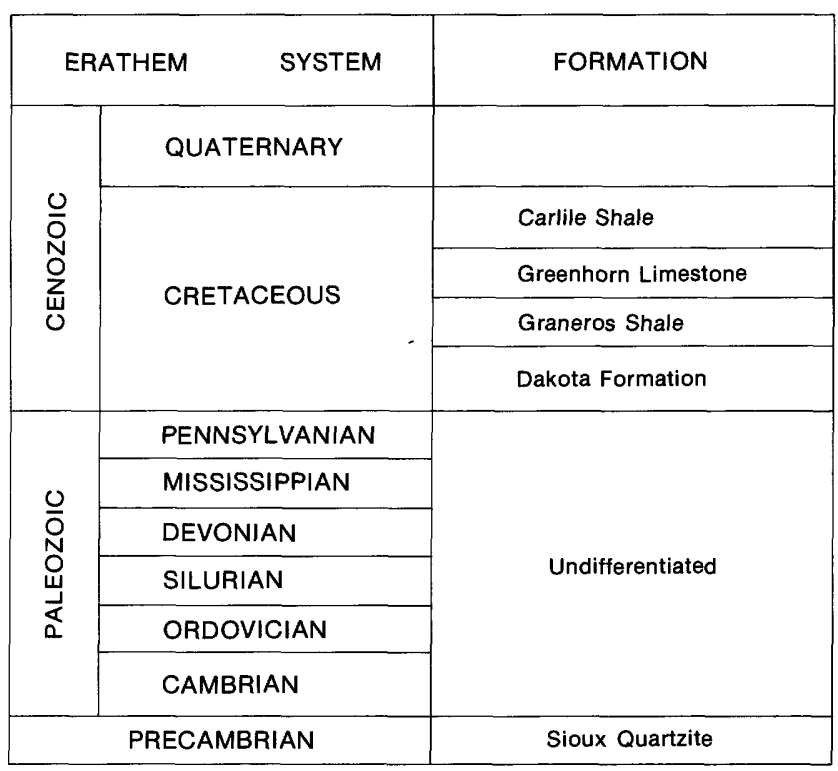

Figure 2. Geologic units used in this report.

For this report, the top of the Dakota aquifer is defined in most areas as the first sandstone below the Greenhorn Limestone or, where the Greenhorn is not present, the first sandstone below the bedrock top. Where a Quaternary sand or gravel is in contact with a sandstone in the Dakota aquifer, the top of this sand or gravel is the top of the aquifer and is included in the total thickness of the aquifer.

The base of the Dakota aquifer is the bottom of the lowest sandstone in the Dakota Formation. In many areas the base of the aquifer conforms to the pre-Cretaceous surface shown on plate 1 .

\section{Distribution of Materials}

Three groups of rock types have been recognized in the Dakota Formation in the study area. These are (1) sandstone, (2) shale and siltstone, and (3) a group consisting of approximately equal parts of thin-bedded shale, siltstone, and sandstone (Whitley, 1980). The sandstone group is commonly found at or near the base of the Dakota Formation whereas the shale and siltstone group is found near the top (Whitley, 1980; Ludvigson and Bunker, 1979). Between the sandstone group and the shale and siltstone group are thin-bedded sandstone, siltstone, and shale beds. This intermediate group is both laterally and vertically transitional with the sandstone and shale groups.

The distribution and composition of sandstone bodies in the Dakota Formation is of primary concern in this report. The cross sections on plate 2 and the total sandstone-thickness map on plate 3 are included to show the regional distribution and position of major sandstone 
units. However, significant local variations from the regional trends in total sandstone thickness may exist throughout the study area.

The sandstone comprising the Dakota aquifer occurs in beds that range from less than 10 feet to more 150 feet thick. Beds less than 5 feet thick are not included in the total thickness of the aquifer. The base of the Dakota Formation is generally sandstone with a basal shale occurring more frequently in the eastern part of the study area than in the west (plate 2). Generally, more shale occurs in the upper part of the Formation. Where a complete section of the Dakota Formation exists, particularly along the western part of the study area, the uppermost sequence includes a few sandstones, most of which are very thin or contain significant quantities of material finer than sand size. Because the sandstone units are frequently separated by shale or siltstone, the potential for water exchange among the sandstone bodies is restricted by the thickness, extent, and hydraulic properties of the interbedded material. This factor is particularly important when considering local flow systems. However, in evaluating the regional flow system, the sandstones are considered as a unit.

The individual sandstone beds are composed of from fine to coarse sand, some gravel, and variable amounts of silt and clay. Coarse sand is very common, particularly in the lower part of the formation. Sandstone beds are generally coarser grained near the top then near the base (Whitley, 1980), although some are finer grained upward. Sorting of grain sizes within the sandstone bodies likely results in greater hydraulic conductivity than that expected of poorly sorted sandstones. Sample descriptions indicate very little cementation of the sandstone. The sandstone is occasionally interbedded with siderite (iron carbonate) and contains abundant pyrite (iron sulfide) nodules in some locations. Siderite may be incorrectly described as dolomite in some of the logs in table 2 .

The thickness of sandstone in the aquifer appears to be related to the pre-Cretaceous and bedrock topographic surfaces. The surface mapped on plate 1 was drawn to conform with the Precambrian surface in southern Minnesota (Anderson and others, 1976). The bedrock topographic surface on plate 4 was drawn to match the preglacial topography (Anderson and others, 1976) and the bedrock topography immediately east of the study area (Hansen, 1978).

The thickest (more than 200 feet) sandstone sequences (plate 3) in the Dakota aquifer are associated with the elongate depressions in the pre-Cretaceous surface (plate 1). Major areas of thick sandstone include north central Plymouth County, central and southern Sioux County, central Woodbury County, west-central Cherokee County and northeastern O'Brien County northeast into Dickinson County. In many of the areas where the bedrock surface (plate 4) intersects the Dakota aquifer, bedrock valleys coincide with a decrease in total sandstone thickness. For example, plate 4 shows a relatively deep bedrock valley in eastern Woodbury and southeastern Plymouth Counties and plate 3 shows a significant change in sandstone thickness in the same area. The bedrock valley is also shown on section $\mathrm{C}-\mathrm{C}^{\prime}$, plate 2 , between test wells 88-44-06BAAB and 87-41-05CCCC. Other bedrock depressions and valleys shown in sections $A-A^{\prime}$ and $B-B^{\prime}$ illustrate the coincidence in sandstone thickness and bedrock valleys.

The areas on plate 3 outlined by the zero (0) contour line are where the Dakota aquifer does not exist because of non-deposition or lack of sandstone. These areas include the bedrock channel in eastern Woodbury County and the long narrow bedrock channel that extends through much of the eastern third of the study area (plate 4). Also included is the Manson area of anomalous crystalline rocks (Hoppin and Dryden, 1958; Holtzman, 1970) in southeastern Pocahontas and northeastern Calhoun Counties and an area in the extreme northwestern part of Lyon County where Precambrian age rocks form the bedrock surface.

The extent and influence of Quaternary sand and gravel deposits on the hydrology of the Dakota aquifer are poorly defined. Data from test holes located at 87-44 15CBBB 1 and 96-34-24BBB (table 2) show that these sand and gravel deposits are in direct contact with the Dakota aquifer. Because the bedrock valleys in the area are the result of Quaternary stream activity, there may be significant amounts of sand and gravel in hydrologic communication with the Dakota aquifer. Most test hole sites in the project area were chosen to evaluate only the Cretaceous sequence of rocks. Consequently, sites in areas outside the bedrock channels were given priority. If these channels contain significant amounts of sand and gravel they could provide an additional highly productive source of water.

\section{Confining Materials}

The Dakota aquifer is confined throughout most of the study area by overlying shale in the Dakota Formation, other Cretaceous-age shale and limestone and Quaternary clay and till. These materials are distinctly less permeable than the sandstone that comprises the aquifer. Till is poorly sorted glacial sediment composed of clay, silt, sand, gravel, and boulders. The shales overlying the aquifer include the mudrock (claystone, silty clay shale, and clayey siltstone) of the Dakota Formation described by Whitley (1980), and the calcareous clay shales of the Graneros Shale and the Carlile Shale. Some characteristics of the materials overlying the aquifer are described in table 2 and a general description of the Cretaceous materials is presented in Whitley (1980) and Whitley and Brenner 
(1981). On plate 3, adjacent to each data point is the depth to the first Cretaceous sandstone at the top of the Dakota aquifer. This value can be used to estimate the total thickness of the overlying confining materials in many areas. However, because the Quaternary material has not been fully investigated, there are areas that may have significant deposits of gravel and sand, which would act as aquifers above the Dakota aquifer, particularly where the Quaternary materials fill a bedrock valley.

The confining material beneath the Dakota aquifer cannot be adequately evaluated from existing data. However, the underlying material consists of shale or mudrocks in the Dakota Formation and limestone, dolomite, shale, and sandstone of Paleozoic age and crystalline rocks of Precambrian age. Cross sections in Ludvigson and Bunker (1979) show a general southeast inclination of the Paleozoic strata. Therefore, the first rock units encountered beneath the Dakota Formation are successively younger toward the southeast. There are several sites where observation wells were initially completed to aquifers (sandstones and carbonates) in the uppermost Paleozoic unit. These wells were later plugged back and perforated in the Dakota aquifer. Also some test hole sites have two wells, one completed in the Dakota aquifer and one completed in an underlying Paleozoic aquifer. With the exception of a site near LeMars, at all these locations the water levels were the same or higher in the Dakota aquifer than in the Paleozoic aquifers. The difference does not exceed 4 or 5 feet at any location but the difference is widely distributed throughout the project area.

\section{WATER AVAILABILITY AND MOVEMENT}

\section{Distribution of Potential Head and Ground-water Flow}

The areal distribution of the level to which water would rise in a well completed in the Dakota aquifer is shown on the potentiometric map (plate 5). The data used to make this interpretation are water levels measured during the calendar years 1979 and 1980 in observation wells drilled for this project and private wells measured during November 1979. Representative water levels reported by drillers and pump contractors were also considered, particularly in areas where no other information was available.

The water levels measured in wells drilled for this project are listed in table 3 . The records included in this table are not sufficient for an evaluation of long-term changes in the aquifer but they provide the basis for the areal interpretations in this report.

The wells from which data were used to produce the map on plate 5 were completed in various sandstones in the Dakota aquifer. It is probable that all the sandstones are hydraulically related; however, the hydraulic head may vary among sandstones at any site. For this reason the potentiometric map presented here may contain some local variations due to the completion of the individual wells. Therefore, the map represents an interpretation of the regional flow and not necessarily details of local flow in the aquifer.

Lateral water movement in the aquifer is generally from the north-central part of the area to the southwest, south, and east. The higher water levels are in the uplands of the north, and lower water levels are mostly near the Big Sioux River along the southwestern border. Stream altitudes were determined from $7-1 / 2$ minute series topographic maps at several points along the Big and Little Sioux, Rock, Raccoon, Des Moines, and Floyd Rivers (plate 5). These data along the Big Sioux River agree with extrapolated regional ground-water levels in the Dakota aquifer along the western edges of Woodbury and Plymouth Counties. In these areas the ground-water flow is directly toward and possibly into the Big Sioux River. At Sioux City, the aquifer directly underlies river alluvium and is exposed in the bluffs along the Big Sioux River. The flow may be directly into the stream or the surrounding alluvium in this area. The aquifer is under water-table conditions.

In Sioux and southern Lyon Counties the Big Sioux River recharges the aquifer. Water levels presented in this report indicate that the flow in the Dakota aquifer is toward South Dakota along this segment of the Big Sioux River.

On plate 5, upstream deflections in the regional potentiometric surface occur near the mouth of the Floyd and part of the Little Sioux Rivers. These deflections indicate flow toward the streams and bedrock valleys (plate 4). The altitude of the Little Sioux River through Cherokee County is consistently lower than the potentiometric surface of the Dakota aquifer (plate 5). This is evidence of a potential for ground-water movement upward into overlying aquifers and ultimately into the Little Sioux River. Municipal withdrawal between the 1160 and 1180 foot contours (plate 5) from Marcus to Alta may have some effect on this relationship. However, the amount of withdrawal has apparently not significantly altered the direction of movement and the water-level history is not adequate to determine the magnitude of any effects of withdrawal.

The deflections in regional potentiometric contours along the eastern part of the study area are a result of flow through the aquifer toward the area where the Cretaceous rocks are absent. A ground-water divide exists from western Pocahontas County to western Dickinson County and regional flow is generally east and southwest away from this divide. Water-level data from the eastern tier of counties are not extensive and much of these data are from drillers' reports rather than from measurements collected as part of this project. The extent of the Dakota 
aquifer is not well known in this area nor are the relationships with Quaternary deposits understood. In this area, the relatively small total thickness of sandstone in the Dakota Formation (plate 3) may result in a more complex potentiometric surface than that shown in plate 5 .

It is assumed that there is flow from the upper sandstone beds to the lower ones within the Dakota aquifer throughout much of the study area. One area where this can be documented is in 98-39-26C, where a group of observation wells were completed to monitor a pump test. Here the water level in a well completed in a shallow and thin Dakota sandstone (98-39-26CDAD2) is consistently about two feet higher than that in another nearby observation well (98-39-26CDCC) completed in the deeper part of the Dakota aquifer. In addition, there are several locations where water levels have been measured in both the Dakota aquifer and underlying Paleozoic aquifers. With the exception of a site near LeMars, all the water levels in the wells penetrating the Dakota aquifer are higher than the water levels in wells completed in the underlying units. This downward head gradient probably is reversed in discharge areas such as along the Big Sioux River.

Hydrographs of four Dakota aquifer observation wells maintained by the United States Geological Survey are shown in figure 3. With the exception of the well at 89-47-22BADC2, they show an overall decline in water levels during the periods of record. The decline appears to be occurring at a relatively uniform rate, indicating that the aquifer has not reached equilibrium with recharge and discharge conditions. The well at 89-4722BADC2, near Sioux City, shows no regular pattern of decline. This may be a result of the water-table conditions in the aquifer in that area and the changes in pumping patterns at Sioux City.

It is possible that the long-term decline in water levels will continue at a reduced rate if the withdrawal from the aquifer remains at the existing level. Theoretically, a balance will be reached when water levels throughout the aquifer are reduced to the point where in-

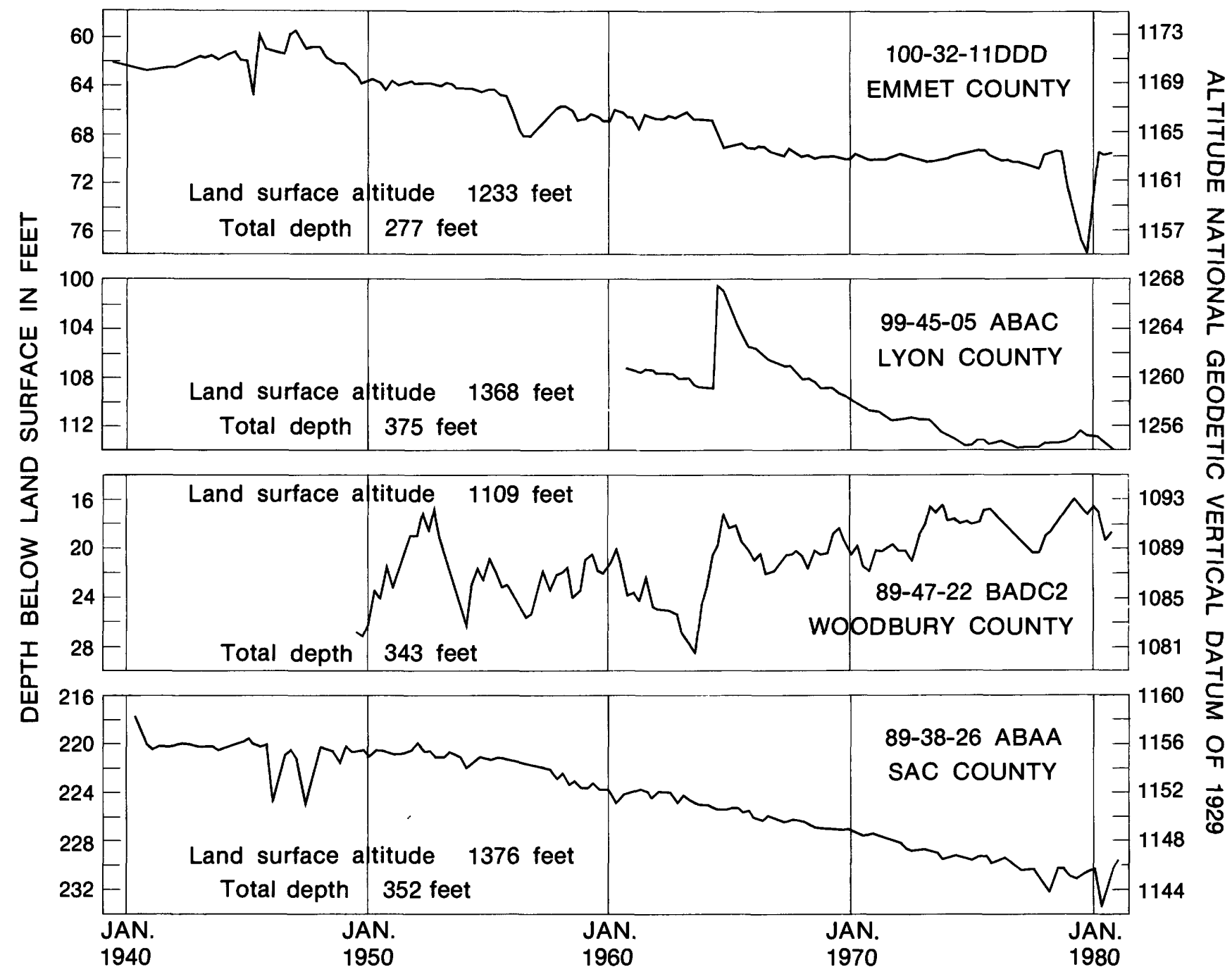

Figure 3. Hydrographs of selected observation wells in the Dakota aquifer. 
duced recharge due to pumping or decreased discharge compensates for withdrawal. However, if pumpage increases, water levels will continue to decline, perhaps at an accelerated rate, to even lower levels before a balance results.

Three of the hydrographs on figure 3 show anomalous water level changes during the 1964 record. Two hydrographs, 99-45-05ABAC and 89-47-22BADC2, show a sudden rise, and hydrograph 100-32-11DDD shows a sudden decline shortly following the time of the March 1964 Alaskan earthquake. The sudden and long-lasting change in water levels in these wells may have been caused by reorientation of aquifer materials and confining units, resulting in changes in porosity and hydraulic conductivity. The change was not the same in all observation wells because of variations in textures of sandstone that comprise the aquifer. A discussion of the effects of the 1964 earthquake on these and other observation wells in Iowa was presented by Coble (1965).

\section{Transmissivity}

Data used to calculate transmissivity have been collected from the Dakota aquifer at five pumping test sites. These pumping tests were conducted and (or) analyzed by staff of the Iowa Geological Survey. The results of three tests, Hanson at 97-46-28, Ritz at 92-47-31, and Hosteng at $87-35-30$, were published in Ludvigson and Bunker (1979). Table 4 is a summary of the results of all five tests.

Regional interpretation of the transmissivity depends on interpolation between points where test data exist. The method of interpolation used in this report was to relate transmissivity to the aquifer material at the pumping test sites. It was assumed that observed relationships between transmissivity and aquifer materials are consistent throughout the aquifer. Table 4 includes the average hydraulic conductivity at each site, calculated by dividing the transmissivity by the average thickness. The average hydraulic conductivity for all sites is approximately 40 feet per day. The range of average hydraulic conductivities is very small compared to the possible errors in calculating the transmissivity. These errors may be very large because the thickness of the Dakota aquifer changes locally over short distances. However, because the hydraulic conductivities at all the pumping test sites are similar, it is assumed that the conductivity of the Dakota aquifer is regionally uniform. To obtain an estimate of the transmissivity of the aquifer in any area, multiply the sandstone thickness shown on plate 3 by the average hydraulic conductivity (40 feet per day). This is an intermediate calculation used to estimate the potential yield discussed in a later section and shown on plate 6 . Because this report is a regional appraisal of the Dakota aquifer, only approximate condi- tions are presented in untested areas. A more detailed analysis may be needed to precede any specific development plans.

\section{Discharge and Recharge}

Natural recharge to the Dakota occurs where the potentiometric surface is below a surface-water source or an aquifer that has a higher potentiometric surface. This source may be adjacent confined aquifers and overlying water-table aquifers or surface-water bodies such as lakes, potholes, and streams. These sources may be positioned above, below, or adjacent to the Dakota aquifer. Conversely, natural discharge occurs where the potentiometric surface of the Dakota aquifer is higher than other such surfaces. Exchange of water can occur directly, or through very thick confining layers. Rates of recharge and discharge will vary depending on the permeability and thickness of the confining layers, and the magnitude of the head differences.

Recharge occurs to the Dakota aquifer directly from precipitation where the Dakota aquifer is exposed at the land surface and from leakage from lakes, streams, and overlying aquifers. The potential for direct recharge of the Dakota aquifer from streams in the study area is limited to the area near the Big Sioux River in Plymouth and northern Woodbury Counties. The recharge here is limited to areas where sandstone in the Dakota aquifer outcrops and occurs only when stream levels are above the sandstone exposures. However, the regional flow pattern shown on plate 5 indicates potential for discharge to the stream exceeds any local or short-term recharge in that area.

Recharge to most of the Dakota aquifer is indirectly from the water table through confining material or from aquifers overlying the Dakota aquifer. Because the confining materials, mostly shale, till, and loess, have a very small hydraulic conductivity, the rate of recharge is very small. The rate at which water enters the Dakota aquifer depends upon: (1) the hydraulic conductivity of the confining material, (2) the thickness of the confining material, and (3) the difference in altitude between the water table and the potentiometric surface of the Dakota aquifer.

In the absence of a detailed analysis of the confining material, it is difficult to assess the volume of recharge. However, for a regional analysis, a range of recharge volume can be approximated. The rate of flow through the confining layer can be expressed as (Bredehoeft and Pinder, 1970):

$$
\mathrm{q}=\mathrm{K}^{\prime}\left(\mathbf{h}-\mathrm{h}^{\prime}\right) / \mathbf{l}
$$

where:

$q=$ rate of flow into the aquifer per unit area, in feet per day 
$\mathbf{K}^{\prime}=$ vertical hydraulic conductivity of the confining layer, in feet per day

$l=$ thickness of the confining layer, in feet

$\mathrm{h}=$ head in the water table, in feet

$h^{\prime}=$ head in the confined aquifer, in feet

Assumptions can be made to estimate $\left(\mathrm{h}-\mathrm{h}^{\prime}\right)$ and $I$ in the formula above. The water table throughout most of the study area is within 20 feet of the land surface. The average depth to water in observation wells of the Dakota aquifer shown in table 3 is approximately 150 feet. The difference of 130 feet can be used as an estimate of $h-h^{\prime}$. The average depth to the Dakota aquifer in the wells shown in table 2 is approximately 275 feet. Because the water must move from the water table to the top of the aquifer the average thickness of the confining layer (l) is estimated to be 255 feet. The errors in estimating these two factors are not significant when compared to the possible error of estimating the vertical hydraulic conductivity of the confining material.

Information regarding the confining material above the Dakota aquifer in the study area is mostly qualitative. Vertical hydraulic conductivity for the confining unit overlying the Dakota aquifer is estimated by comparing the confining materials to published values of conductivity for similar materials. Freeze and Cherry $(1979$, table 2.2 , p. 29) summarized a range of hydraulic conductivity values for materials similar to those that constitute the confining layer. These include: till, 1.3 to 0.0000013 feet per day; loess, 13 to 0.0013 feet per day; and unweathered marine clay (similar to the Cretaceous shales), 0.0013 to 0.00000013 feet per day. For this example it is assumed that the confining unit has an average hydraulic conductivity range of 0.0013 to 0.000013 feet per day. This range is toward the smaller values of the range of conductivities suggested by Freeze and Cherry. This choice of values should produce a relatively low estimate of the recharge potential. Kunkle (1968) determined the leakage rate through till in east-central Iowa to be 0.0005 feet per day. This value supports the approximation of a low estimate for this parameter.

Using the values of $\left(h-h^{\prime}\right)=130$ feet, $1=255$ feet and $K^{\prime}=0.0013$ and 0.000013 feet per day, the range of recharge rate, $\mathrm{q}$, is 0.00067 to 0.0000067 feet per day.

Natural discharge from the Dakota aquifer occurs where the potentiometric surface in the Dakota aquifer is higher than that in nearby aquifers. The aquifers receiving water in such a process may be Quaternary sand and gravel deposits above the Dakota, the bedrock valleys that are laterally adjacent to the Dakota, and the Paleozoic rocks underlying the Dakota aquifer. The cross sections on plate 2 show the relative position of the bedrock valleys. However, little is known about the distribution of potential water-bearing material in these valleys. The potentiometric map of the Dakota aquifer, plate 5 , shows potential for flow through the Dakota aquifer toward the southeastern part of the study area where a bedrock valley is interpreted and toward the bedrock valley in eastern Woodbury County. The flow toward these valleys is indirect evidence that significant aquifers with lower heads are likely in the materials that fill these valleys. It is not possible to estimate the leakage from the Dakota in these areas without more extensive data than are currently available.

Water levels gathered for this study indicate that, with local exceptions discussed later, there is leakage from the Dakota aquifer to underlying aquifers in Paleozoic rocks. At several test sites, observation wells were established in aquifers in Paleozoic or Precambrian rocks. After a static water level was measured and a water sample was taken, the wells were plugged at the bottom with cement. After perforation with an explosive wire-line device, an observation well was developed in the Dakota aquifer at most of these sites. These sites, and sites where at least two separate wells in the Dakota and underlying aquifers were completed, are as follows:

87-44-15CBBB 91-39-01ADAD 94-47-35AAAB 100-39-17DCCB 89-46-36BBDC 91-42-16DDDD 98-39-26CDAD 100-48-31CCCC 90-38-16DDDD 92-45-02CBCB 98-42-33AABB

With the exception of three of the sites listed above, the measured values of head in the Dakota aquifer are higher than in the underlying Paleozoic or Precambrian unit, table 3 . At two of these sites, 100-39-17DCCB and 100-48$31 \mathrm{CCCC}$, the head in the underlying unit is less than one foot higher than in the Dakota aquifer. A third site, 92$45-02 C B C B$, is apparently within the area affected by pumpage from the Dakota aquifer in the LeMars area, and consequently water may be moving upward from aquifers in Paleozoic rocks. This represents a reversal of the regional direction of flow.

The wide distribution of heads higher in the Dakota aquifer than those in the aquifers in Paleozoic rocks indicates that these aquifers are recharged in part by the Dakota aquifer. Among the aquifers in Paleozoic rocks are the Ordovician St. Peter and Cambrian Jordan aquifers as well as Devonian carbonate aquifers (Ludvigson and Bunker, 1979). A quantitative estimate of the flow from the Dakota into these units is not possible from available data.

The direction of downward leakage can be reversed by withdrawals from the Dakota, such as the pumping in the LeMars area. At test site 92-45-02CBCB, approximately two miles northeast of the LeMars municipal wells, one observation well is completed to the Dakota aquifer (92-45-02CBCB2) and a second is cased through the Dakota and open to Paleozoic age rocks (92-4502CBCB1). At this site the head in the Dakota aquifer is consistently lower than the head in the Paleozoic aquifers. Water levels in both wells declined during April 
through September, table 3, apparently in response to increased pumping during that period. The effects of leakage from the Paleozoic aquifers to the Dakota aquifer are seen in the quality of water pumped from wells in the Dakota aquifer in the area (plates 7 and 8).

Withdrawal from the Dakota aquifer in the study area is dominantly for municipal water supplies. Several industrial and irrigation wells also use water from the Dakota, but these wells are not metered. The 32 municipalities that use water from the Dakota and the average daily withdrawal are shown on plate 5 .

The withdrawal rates were obtained from the Iowa Department of Environmental Quality, Spencer, Iowa. In 1979 the average withdrawal ranged from 9,000 gallons per day at Oyens to more than $13,000,000$ gallons per day at Sioux City. Excluding Sioux City, the total municipal withdrawal from the Dakota aquifer in the study area in 1979 was $6,500,000$ gallons per day, about 52 percent of which was pumped by the cities of LeMars and Cherokee.

Because one of the principal demands for water in the study area is for irrigation, it is interesting to compare the amount of water needed for irrigation with the municipal demands. An irrigation system supplying 160 acres with 12 inches of water annually would withdraw approximately 52,000,000 gallons per year. Of the 32 municipalities shown on plate 5,22 used less than this amount and 10 used more in 1979. It would take more than 95 such irrigation systems to equal the municipal withdrawal of Sioux City and approximately 140 systems to equal the total 1979 municipal withdrawal from the Dakota aquifer in the study area.

\section{Estimated Potential Yield}

One way to demonstrate the regional variations in productivity of an aquifer is to show how much water is potentially available to wells that penetrate the aquifer. The potential yield, as used in this report, is the amount of water that can be pumped from a 100 percent efficient well penetrating the entire aquifer under ideal conditions. The amount that can be pumped will vary with the amount of available drawdown in the pumping well.

The method used in this report to calculate the potential yield determines the specific capacity based on estimates of transmissivity. Specific capacity is a measure of the productivity of a well and is defined as the pumping rate per unit of water level drawdown in the well. Meyer (1963) published a graph relating specific capacity, storage coefficient, and transmissivity. The storage coefficient is a dimensionless property of an aquifer that reflects the amount of water that is released from or added to storage per unit surface area of aquifer, per unit hydraulic head change. The ratio of transmissivity to specific capacity is about 267:1 under the following conditions (Meyer, 1963):
a. the transmissivity of the aquifer is within the range 270 to 13,400 feet squared per day;
b. the storage coefficient is less than 0.005; and
c. the specific capacity is given in gallons per min- ute per foot of drawdown after 24 hours pumping.

From table 4 it can be seen that all of the transmissivities calculated from the five pumping tests fall in the range of 270 to 13,400 feet squared per day. Estimates of the storage coefficient (Jim Munter, written commun., 1981) are all less than 0.005 .

Plate 6 shows regional estimates of potential yield. The transmissivity was determined by the product of sandstone thickness (plate 3) and average hydraulic conductivity, which is assumed to be 40 feet per day. The transmissivity was then divided by 267 , resulting in a specific capacity in units of gallons per minute per foot of drawdown. For this report an arbitrary drawdown of 20 feet was multiplied by the specific capacity to determine the potential yield shown on plate 6 .

As an example of this method, on plate 3 , in Plymouth County T. 91 N. R. 44 W. the total thickness of sandstone is shown to be about 150 feet. The potential yield of this thickness of sandstone is determined by first multiplying the thickness by 40 feet per day (average hydraulic conductivity). This results in a transmissivity of 6,000 feet squared per day. Dividing this transmissivity by 267 (ratio of transmissivity to specific capacity) results in a specific capacity of 22.5 gallons per minute per foot of drawdown. The final step is to multiply the specific capacity by the drawdown ( 20 feet for this report), giving a potential yield of 450 gallons per minute. On plate 6 , the same location shows the area to have a potential yield of 100 to 500 gallons per minute. The area is near the 500 gallons per minute line.

If drawdown of more than 20 feet in the producing well is acceptable, then the potential yield will be greater than that shown on plate 6 . Conversely, if 20 feet of drawdown is excessive then the potential yield will be less than that on plate 6 . Of course, no well is 100 percent efficient so the actual yield will be reduced by the well efficiency factor. The values shown on figure 6 are to be used as a guide to understanding the regional availability of water from the complete Dakota aquifer.

\section{WATER QUALITY}

\section{Major Dissolved Constituents}

Water samples from the Dakota aquifer were collected from 28 of the wells drilled for this project. These samples were analyzed by the University of Iowa, 
Hygienic Laboratory. In addition to these analyses, the most recent analyses available from the various municipal wells in the Dakota aquifer in the area are included in table 5.

Water from the Dakota aquifer can be generally characterized as a calcium-magnesium sulfate type. It is very hard (from 180 to $1,600 \mathrm{mg} / \mathrm{L}$ as calcium carbonate) and has a relatively high dissolved solids content (from 279 to $2,820 \mathrm{mg} / \mathrm{L}$ ). Many samples contain quantities of radionuclides in excess of recommended limits (table 1 ). Nitrate and fluoride are below the recommended limits, and only one sample exceeded the recommended limit for chloride.

The dissolved sulfate content in water from the Dakota aquifer exceeds 1,000 milligrams per liter $(\mathrm{mg} / \mathrm{L})$ (plate 7) throughout much of the study area. About 20 percent of the samples have more than $1,000 \mathrm{mg} / \mathrm{L}$ sulfate. Sulfate content is highest in areas of recharge, particularly the north-central part of the study area. Sulfate content is less than $250 \mathrm{mg} / \mathrm{L}$ in much of the southern and western parts of the area, down-gradient from the major recharge area. Approximately 17 percent of the samples have less than $100 \mathrm{mg} / \mathrm{L} \mathrm{SO}_{4}$. The high sulfate content in the recharge areas may result from solution of sulfate minerals such as gypsum $\left(\mathrm{CaSO}_{4} \cdot 2 \mathrm{H}_{2} \mathrm{O}\right)$ or anhydrite $\left(\mathrm{CaSO}_{4}\right)$ by water as it moves through the Quaternary deposits and Cretaceous rocks that form the confining units and through the Dakota aquifer itself. However, data on rock chemistry are needed to verify the assumption.

Both the dissolved solids (plate 8 ) and the sulfate distribution (plate 7) show anomalies in the central part of Plymouth County, near LeMars. The concentrations of both (TDS) and sulfate in this area are much higher than in nearby wells. This anomaly is likely caused by a reversal of the natural flow direction between the Dakota and the underlying aquifer in Paleozoic rocks. At sites where it was possible to analyze water from both aquifers, the samples from aquifers in underlying Paleozoic rocks had higher concentrations of dissolved solids and sulfate than did the samples from the Dakota aquifer. The water levels in observation wells $92-45-02 B C B 1$ and $92-45-02 B C B 2$ indicate there is potential for flow from the aquifers in the Paleozoic rocks to the Dakota aquifer in this area. Therefore, the water sampled in the LeMars area wells probably represents a local change in quality of natural water in the Dakota aquifer by leakage and mixing of water from the underlying Paleozoic rocks.

Thorstenson, Fisher, and Croft (1979) presented a process to explain changes in dissolved sulfate in an aquifer comprised of rocks of the Cretaceous Fox Hills Formation of North Dakota and South Dakota. In this process anaerobic bacterial action reduces the sulfate in the aquifer to sulfide and uses the oxygen for metabolism of organic material such as lignite. Carbon dioxide and hydrocarbons such as methane are produced by decomposi- tion of organic matter in the later phase of the reducing process.

The rocks and water chemistry studied by Thorstenson, Fisher, and Croft (1979) are very similar to the Dakota aquifer in this study area. Both involve rocks that include sandstone, shale, and lignite. Therefore, the decrease in concentrations of sulfate within the Dakota aquifer could be explained by anaerobic reduction. The conversion of sulfate to sulfide is supported by the occurrence of an iron sulfide mineral, pyrite, in the Dakota Formation and observations of hydrogen sulfide gas in some of the test wells, particulary in the southern ansd western parts of the area. Gases, possibly carbon dioxide and methane, have also been reported from wells that penetrate the Dakota Formation. Unfortunately, dissolved gas samples, which could help support the reducing conditions hypotheses, were not collected.

Iron and manganese are generally present in quantities exceeding the suggested limits shown in table 1 . About 80 percent of the samples contained more than 300 $\mu \mathrm{g} / \mathrm{L}$ (micrograms per liter) iron and 56 percent contained more than $50 \mu \mathrm{g} / \mathrm{L}$ manganese. An analysis of the distribution of these two cations is difficult because their source and sensitivity to chemical conditions in a well may be affected by well construction and the casing materials used. Because of the rapid precipitation of iron and manganese upon exposure to air, special sampling techniques are necessary to obtain consistently satisfactory samples in the field.

\section{Radionuclides}

The data on the radionuclides, radium, gross alpha, and gross beta activity are significantly fewer than for other constituents because these parameters are analyzed using a screening procedure. When gross alpha activity exceeds $5 \mathrm{pCi} / \mathrm{L}$ (picocuries per liter), an equivalent sample is analyzed for radium-226. If the concentration of radium-226 exceeds $3 \mathrm{pCi} / \mathrm{L}$, an equivalent sample is analyzed for radium-228. Approximately 75 percent of all the samples were analyzed for gross alpha, about 50 percent for radium-226 and about 12 percent for radium-228. The data in table 5 include 4 samples that exceed the recommended limits of $15 \mathrm{pCi} / \mathrm{L}$ gross alpha (municipal wells in Arthur, Holstein, Sioux City, Maurice, and Primghar); 9 that exceed $5 \mathrm{pCi} / \mathrm{L}$ radium-226 (municipal wells in Arthur, Holstein, Sioux City, Cherokee, LeMars, and West Bend), 4 that exceed $5 \mathrm{pCi} / \mathrm{L}$ radium-228 (test wells at 91-42-16DDDD, 92-48-06DDDA, 95-43-07AAAA, and 96-44-08ADAA). Fourteen samples exceed $5 \mathrm{pCi} / \mathrm{L}$ radium-226 and radium-228 combined (municipal wells in Arthur, Holstein, Sioux City, West Bend, and Hull; test wells at 94-47-35AAAB and 95-47-05AAAA; and the 
test wells listed above). A statistical summary of radium226 in water from the Dakota aquifer and other aquifers in Iowa is presented in Mackey (1976).

\section{Quality of Water for Irrigation}

Three important factors with respect to dissolved solids are involved in appraising the usability of water for irrigation: (1) the mineral species in the soil and the drainage properties of the soil, (2) the tolerance of the irrigated crop to the major constituents in the water, and (3) the concentration of major constituents in the water. It is not within the scope of this report to evaluate more than the constituents in the water, but it is important to understand that the greater the quantity of dissolved constituents in the water the narrower the range of soils and crops to which the water can successfully be applied.

The method used in this report to classify irrigation water involves the sodium and salinity hazards. This method, developed by the U.S. Salinity Laboratory Staff (1954), uses electrical conductivity (specific conductance) of the water to measure the salinity hazard and the sodium adsorption ratio (SAR, described below) to evaluate the sodium hazard. Figure 4 is a graphic form of this classification system.

The electrical conductivity of water is a sufficiently accurate indirect measurement of the total concentration of dissolved salts to estimate the salinity hazard. Because the relationship between dissolved salts and conductivity is more logarithmic than linear, the left-to-right axis in figure 4 is on a logarithmic scale. The divisions of the salinity hazard are based on the following criteria developed by the U.S. Salinity Staff (1954): (1) most water supplies used successfully for irrigation over long periods of time have had conductivities of less than 2,250 micromhos (per centimeter at 25 degrees C), (2) water in the range of 750 to 2,250 micromhos has been used but will produce saline soil conditions if adequate drainage and leaching are not provided, and (3) water with conductivity of less than 750 micromhos is considered satisfactory, although conductivity values above 250 micromhos may contain dissolved salts in excess of the tolerance of sensitive crops.

The sodium adsorption ratio is a measure of the relative concentration of the ions of calcium, magnesium, and sodium. The formula for calculating the SAR is:

$$
\mathrm{SAR}=\frac{\mathrm{Na}^{+}}{\sqrt{\left(\mathrm{Ca}^{++}+\mathrm{Mg}^{++}\right) / 2}}
$$

where $\mathrm{Ca}^{++}, \mathrm{Mg}^{++}$and $\mathrm{Na}^{+}$are the concentrations in milliequivalents per liter of the respective ions. To convert values from milligrams per liter, as shown in table 5, to milliequivalents, multiply those of Ca by $0.04990, \mathrm{Mg}$

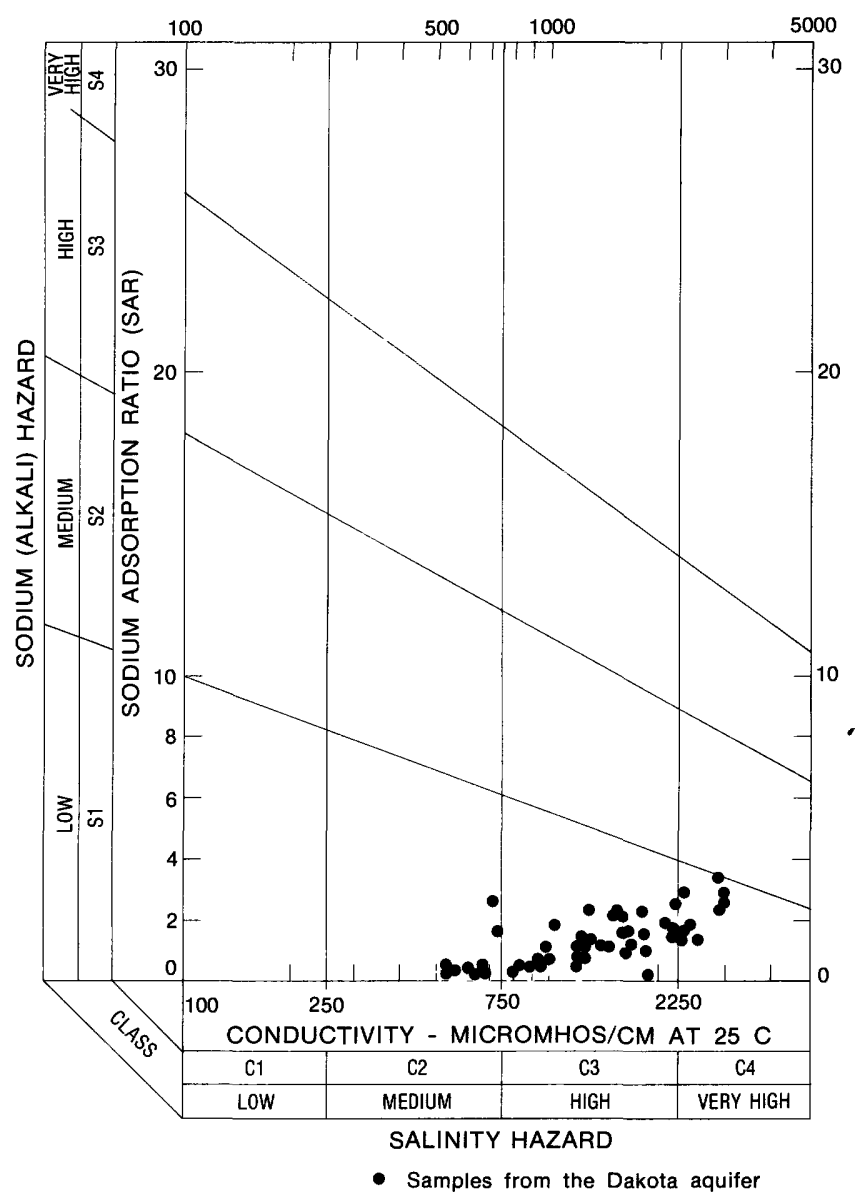

Figure 4. Irrigation classification of water from the Dakota aquifer.

by 0.08224 , and $\mathrm{Na}$ by 0.04350 . These ions may become attached (adsorbed) to the clay minerals in the soil when chemical and moisture conditions in the soil are favorable. When the proportion of sodium ions is high, sodium will replace the calcium and magnesium ions in the clays and the sodium hazard of the soil will rise. When concentrations of calcium and magnesium ions are proportionately high, the process will be reversed and the sodium hazard in the soil will be reduced. An alkali- or sodium-rich soil can be formed by the continuous addition of water with a high SAR.

The following descriptions provide a guide to the use of the diagram on figure 3, summarized from U.S. Salinity Staff (1954):

Low salinity water $(\mathrm{C} 1)$ can be used on most crops and soils. Some leaching is necessary, so soils with extremely low permeability may be affected.

Medium salinity water $(\mathrm{C} 2)$ can be used if soil permeability and drainage are sufficiently high.

High salinity water (C3) should not be used on soils with low permeability. Even with adequate drainage, crops with low salt tolerance may be adversely affected.

Very high salinity water (C4) is not suitable for irri- 
gation water under most conditions. The soils must be permeable, drainage adequate, and considerable leaching provided.

Low sodium water (S1) can be used on most soils with little danger of development of hazardous levels of exchangeable sodium.

Medium sodium water (S2) will present problems in fine-textured soils with high cation exchange capacity.

High sodium water (S3) may produce harmful levels of sodium in most soils.

Very high sodium water (S4) is generally unsatisfactory for irrigation purposes except at low salinity, where solution of calcium from the soil or the use of a soil additive may make irrigation with this type of water possible.

Using the classification described above, water from the Dakota aquifer generally has a low sodium hazard. Figure 3 is a plot of the water samples from table 5 . The salinity hazard, however, may be a problem where the water has a high conductivity, particularly in excess of 2,250 micromhos $/ \mathrm{cm}$. In addition, water with a conductivity greater than 750 micromhos $/ \mathrm{cm}$ may require specific soil and crop analysis before extensive irrigation is planned. The requisites for irrigation with these marginal classes of water include adequate drainage of the soil and availability of sufficient quantities of water to leach any soil that has a relatively low permeability.

\section{SUMMARY AND CONCLUSIONS}

The Dakota aquifer is the most extensive source of large quantities of ground water in northwestern Iowa. The aquifer is composed of multiple layers of sandstone in the Cretaceous Dakota Formation. For this report Quaternary sand and gravel deposits that are directly in contact with these sandstones are included in the aquifer. Individual sandstone layers are separated by shale, and the thickness of the individual sandstone beds varies from a few inches to more than 150 feet. The composite thickness of sandstone is more than 200 feet throughout much of the western and north-central parts of the study area.

The Dakota aquifer is confined by a sequence of overlying Cretaceous shales and limestones and Quaternary till and loess. Beneath the aquifer are shales of the Dakota Formation and Paleozoic shales, carbonate rocks, sandstones and Precambrian crystalline rocks.

Lateral movement of water through the aquifer is from the north-central part of the area to the south, southwest, and east. The aquifer is under water-table conditions in the extreme southwestern part of the study area near the Big Sioux and Missouri Rivers. Water recharges the aquifer throughout the study area through overlying confining units. Discharge through the overlying material occurs along the west-central part of the study area beneath the Big Sioux River valley where the potientiometric surface is above the river. Regional gradients indicate flow in the aquifer is toward South Dakota. Discharge from the aquifer occurs along the bluffs of the southern end of the Big Sioux River and along the Missouri River where the Dakota aquifer is exposed at the surface.

The results of pumping tests in the study area indicate the hydraulic conductivity of the Dakota aquifer ranges from 37 to 50 feet per day. For purposes of estimating potential yield throughout the aquifer, 40 feet per day was multiplied by the cumulative thickness of sandstone comprising the aquifer. The resulting transmissivity determination was used to estimate the potiental yield of the aquifer.

Estimated potential yields to wells completed in the Dakota aquifer exceed 250 gallons per minute throughout much of the study area. The estimates were made assuming only 20 feet of drawdown in pumping wells. Production of greater quantities of water is possible if more than 20 feet of drawdown is acceptable.

The quality of water from the Dakota aquifer is typically a calcium-magnesium sulfate type. Sulfate and dissolved solids are most abundant in the recharge areas. Sulfate concentrations commonly exceed $1,000 \mathrm{mg} / \mathrm{L}$ and dissolved solids exceed $2,000 \mathrm{mg} / \mathrm{L}$ in these areas. However, sulfate content is less than $250 \mathrm{mg} / \mathrm{L}$ in much of the area with lower hydraulic heads. Evidence, which includes observed hydrogen sulfide gas and pyrite nodules, indicates that the sulfate may be undergoing biochemical reduction within the aquifer.

The quality of water pumped from the Dakota aquifer may be altered by leakage from the underlying Paleozoic aquifers if large withdrawals reverse the natural flow from the Dakota into the Paleozoic aquifers. An example of this reversal may exist near the city of LeMars where water from the Dakota aquifer has a dissolved solids and sulfate content that is abnormally high for the area. This is also the only area where the head in the Dakota aquifer is known to be below that in the aquifers in Paleozoic rocks. In this area, water from aquifers in Paleozoic rocks contains higher concentrations of TDS and sulfate than water from the Dakota aquifer.

There are insufficient data on radionuclides to make a regional interpretation of distribution, but several of the samples indicate radionuclides occur in quantities that exceed the limit for gross alpha activity, radium-226, radium-228, or a combination of these constituents.

The quality of water from the Dakota is generally suitable for irrigation purposes. However, there are areas where the water has a relatively high salinity hazard, as measured by electrical conductivity. In these areas a careful evaluation of soil, drainage, crop tolerances, and irrigation rates may be necessary before water from the Dakota aquifer is applied to soils containing a large percentage of clays. 


\section{REFERENCES CITED}

Anderson, H. W., Jr., Broussard, W. L., Farrell, D. F., and Felsheim, P. E., 1976, Water resources of the Rock River watershed, southwestern Minnesota: U.S. Geological Survey Hydrologic Investigations Atlas HA-555, 3 plates.

Anderson, H. W., Jr., Broussard, W. L., Farrell, D. F., and Huit, M. F., 1976, Water resources of the Des Moines River watershed, southwestern Minnesota: U.S. Geological Survey Hydrologic Investigations Atlas HA-553, 3 plates.

Bredehoeft, J. D., and Pinder, G. F., 1970, Digital analysis of areal flow in multiaquifer groundwater systems: A quasi three dimensional model: Water Resources Research, v. 6 , no. 3, p. 883-888.

Coble, R. W., 1965, The effects of the Alaskan earthquake of March 27, 1964, on ground water in Iowa: Iowa Academy of Science, v. 72, p. 323-332.

Freeze, R. A. and Cherry, J. A., 1979, Groundwater: Englewood Cliffs, N. J., Prentice-Hall, 604 p.

Hansen, R. E., 1978, Bedrock topography of north-central Iowa: U.S. Geological Survey Miscellaneous Investigations Series Map I-1080, 2 plates.

Holtzman, A. F., 1970, Gravity study of the Manson "disturbed area," Calhoun, Pocahontas, Humbolt, and Webster Counties, Iowa: University of Iowa, Unpub. M.S. thesis, $63 \mathrm{p}$.

Hoppin, R. A. and Dryden, J. E., 1958, An unusual occurrence of Precambrian crystalline rocks beneath glacial drift near Manson, Iowa: Journal of Geology, v. 66, no. 6, p 694 699.

Iowa Geological Survey, 1969, Geologic map of Iowa: Iowa Geological Survey, 1:500,000, one sheet.

Kunkle, G. R., 1968, A hydrologic study of the ground-water reservoirs contributing base runoff to Four Mile Creek, east-central Iowa: U.S. Geological Survey Water-Supply Paper 1839-O, 41 p.
Ludvigson, G. A., and Bunker, B. J., 1979, Status of hydrogeologic studies in northwest Iowa: Iowa Geological Survey, Open File Report, September, 1979, 37 p., with Executive Summary, 5 p.

Mackey, Gary W., 1976, Radium-226 and strontium-90 in Iowa groundwater: University of Iowa, Unpub. M.S. thesis, $149 \mathrm{p}$.

Meyer, R. R., 1963, A chart relating well diameter, specific capacity, and the coefficients of transmissivity and storage, in Bentall, Ray, Methods of determining permeability, transmissibility, and drawdown: U.S. Geological Survey Water-Supply Paper 1536-I, p. 338-340.

National Academy of Sciences-National Academy of Engineering, 1973, [1974], Water quality criteria, 1972: U.S. Environmental Protection Agency, Ecological Research Series, Report EPA R3-73-033, March 1973, 594 p.

Thorstenson, D. C., Fischer, D. W., and Croft, M. G., 1979, The geochemistry of the Fox Hills-Basal Hell Creek aquifer in southwestern North Dakota and northwestern South Dakota: Water Resources Research, v. 15, no. 6, p. 1479-1498.

U.S. Salinity Laboratory Staff, 1954, Diagnosis and improvement of saline and alkali soils: U.S. Department of Agriculture, Agriculture Handbook no. 60, 160 p.

Wahl, K. D., Meyer, M. J., and Karsten, R. A., 1981, Hydrology of the surficial aquifer in the Floyd River basin, Iowa: Iowa Geological Survey Water Supply Bulletin No. 12.

Whitley, D. L., 1980, A stratigraphic and sedimentologic analysis of Cretaceous rocks in northwest Iowa: University of Iowa, Unpub. M.S. thesis, 81 p.

Whitley, D. L., and Brenner, R. L., 1981, Subsurface stratigraphic and sedimentologic analyses of Cretaceous rocks in northwest Iowa, in Cretaceous stratigraphy and sedimentation in northwest Iowa, northeast Nebraska and southeast South Dakota: Iowa Geological Survey Guidebook Series no. 4, p. 57-75. 
TABLES 1-5 
Table 1. Major chemical constituents in water, their effects upon usability and their concentration limits

\begin{tabular}{|c|c|c|c|}
\hline \multirow[t]{2}{*}{ Constituents } & \multicolumn{2}{|c|}{$\begin{array}{l}\text { Maximum contaminant } \\
\text { levels in community } \\
\text { water supplies }(1)\end{array}$} & \multirow[t]{2}{*}{ Effects on usability } \\
\hline & $\begin{array}{l}\text { Primary } \\
\text { regulations }\end{array}$ & $\begin{array}{l}\text { Proposed } \\
\text { secondary } \\
\text { regulations }\end{array}$ & \\
\hline $\operatorname{Iron}(\mathrm{Fe})$ & & $300 \mu g / L(2)$ & $\begin{array}{l}\text { If more than } 100 \mu \mathrm{g} / \mathrm{L} \text { is present, it } \\
\text { will precipitate when exposed to air; } \\
\text { causes turbidity, stains plumbing } \\
\text { fixtures, laundry, and cooking } \\
\text { utensils, and imparts tastes and colors } \\
\text { to food and drinks. More than } 200 \mathrm{~g} / \mathrm{L} \\
\text { is objectional for most industrial uses. }\end{array}$ \\
\hline Manganese (Mn) & & $50 \mu \mathrm{g} / \mathrm{L}$ & $\begin{array}{l}\text { More than } 200 \mu g / L \text { precipitates upon } \\
\text { oxidation. Causes undesirable taste } \\
\text { and dark-brown or black stains on } \\
\text { fabrics and porcelain fixtures. Most } \\
\text { industrial uses require water } \\
\text { containing less than } 200 \mu \mathrm{g} / \mathrm{L} \text {. }\end{array}$ \\
\hline $\begin{array}{l}\text { Calcium(Ca) } \\
\quad \text { and } \\
\text { Magnesium }(\mathrm{Mg})\end{array}$ & \multicolumn{2}{|c|}{ Not Applicable } & $\begin{array}{l}\text { Combine with bicarbonate, carbonate, } \\
\text { sulfate and silica to form scale in } \\
\text { heating equipment. Retard the suds- } \\
\text { forming action of soap and detergent } \\
\text { (hardness). High concentration of } \\
\text { magnesium has a laxative effect. }\end{array}$ \\
\hline $\begin{array}{l}\text { Sodium (Na) } \\
\text { and } \\
\text { Potassium (K) }\end{array}$ & \multicolumn{2}{|c|}{ Not Applicable } & $\begin{array}{l}\text { More than } 50 \mathrm{mg} / \mathrm{L} \text { sodium and potassium } \\
\text { with suspended matter causes foaming, } \\
\text { which accelerates scale formation and } \\
\text { corrosion in boilers. }\end{array}$ \\
\hline $\begin{array}{l}\text { Bicarbonate }\left(\mathrm{HCO}_{3}\right) \\
\text { and } \\
\text { Carbonate }\left(\mathrm{CO}_{2}\right)\end{array}$ & \multicolumn{2}{|c|}{ Not Applicable } & $\begin{array}{l}\text { Can combine with calcium and magnesium } \\
\text { to form scale. }\end{array}$ \\
\hline Sulfate $\left(\mathrm{SO}_{4}\right)$ & & $250 \mathrm{mg} / \mathrm{L}(3)$ & $\begin{array}{l}\text { Combines with calcium to form scale. } \\
\text { More than } 500 \mathrm{mg} / \mathrm{L} \text { tastes bitter and } \\
\text { may be a laxative. }\end{array}$ \\
\hline Chloride (Cl) & & $250 \mathrm{mg} / \mathrm{L}$ & $\begin{array}{l}\text { In excess of } 250 \mathrm{mg} / \mathrm{L} \text { may impart salty } \\
\text { taste, greatly in excess may cause } \\
\text { physiological distress. Food process- } \\
\text { ing industries usually require less } \\
\text { than } 250 \mathrm{mg} / \mathrm{L} \text {. }\end{array}$ \\
\hline Eluoride (F) & \multicolumn{2}{|c|}{$\begin{array}{l}\text { Limits very from } 1.8 \text { to } \\
2.2 \mathrm{mg} / \mathrm{L} \text { based on average } \\
\text { maximum daily air temper- } \\
\text { atures. }\end{array}$} & $\begin{array}{l}\text { Optimum concentration has a beneficial } \\
\text { effect on the structure and resistance } \\
\text { to decay of children's teeth. Excess } \\
\text { concentrations may cause mottling of } \\
\text { children's teeth. }\end{array}$ \\
\hline Nitrate $\left(\mathrm{NO}_{3}\right)$ & $45 \mathrm{mg} / \mathrm{L}$ & & $\begin{array}{l}\text { Concentrations in excess of } 45 \mathrm{mg} / \mathrm{L} \text { are } \\
\text { reported to cause methemoglobinemia in } \\
\text { infants. }\end{array}$ \\
\hline Dissolved solids & & $500 \mathrm{mg} / \mathrm{L}$ & $\begin{array}{l}\text { Less than } 300 \mathrm{mg} / \mathrm{L} \text { is desirable for } \\
\text { some manufacturing processes. Exces- } \\
\text { sive dissolved solids restrict the use } \\
\text { of water for irrigation. }\end{array}$ \\
\hline
\end{tabular}


Table 1. Continued

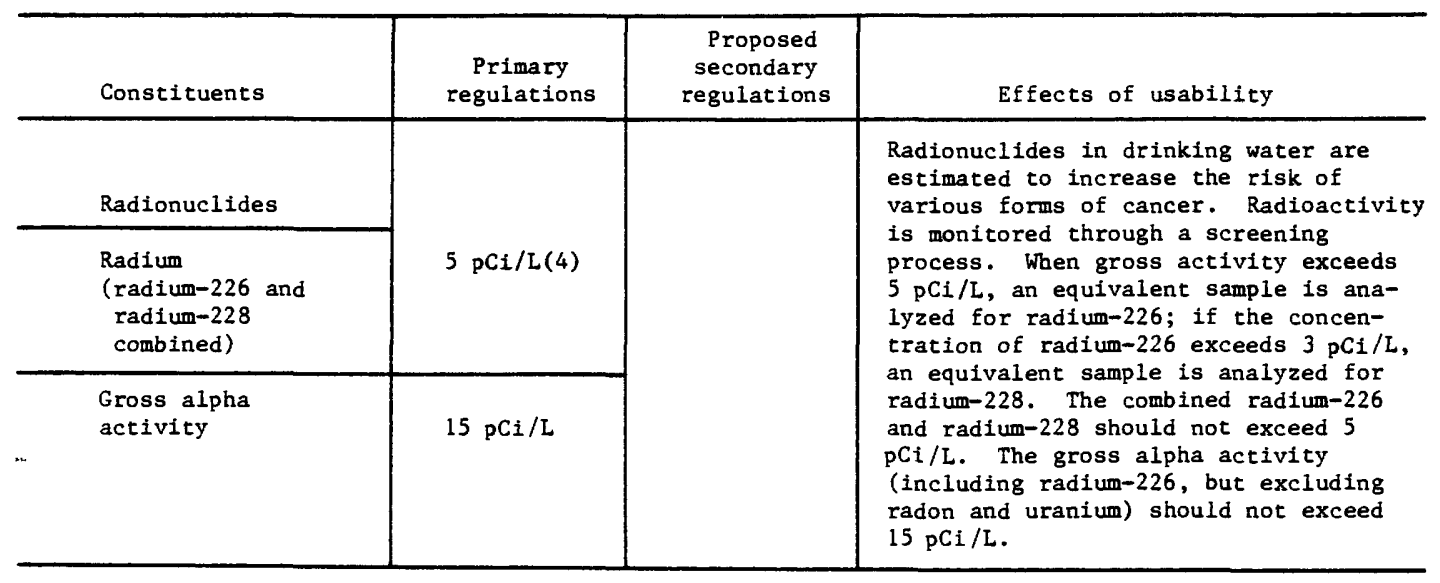

(1)-National Interim Primary Drinking Regulations (Federal Register, v. 40, no. 248 and v. 41, no. 133) and Proposed Secondary Drinking Water Regulations (Federal Register, v. 42 , no. 62 ).

(2) $-\mu z / L-m i c r o g r a m s$ per liter.

(3) $-\mathrm{mg} / \mathrm{L}$-milligrams per liter.

(4) -The State may require annual monitoring of supplies that exceed $3 \mathrm{pCi} / \mathrm{L}$ radium-226. (pCi/L-picocuries per liter). 
Table 2. Logs of selected test holes

[Included is a representative selection of test holes drilled for this project. All test holes which are specifically referred to in the text or used in cross sections have been included. Descrptions of materials are field observations provided by the Iowa Geological Survey. At the top of each $\log$ is the identification used by the Iowa Geological Survey. Altitude datum is the National Geodetic Vertical Datum of 1929 (NGVD, 1929). Depths are shown in feet below land surface. Natural gamma radiation logs are uncalibrated.]

IGS - D34

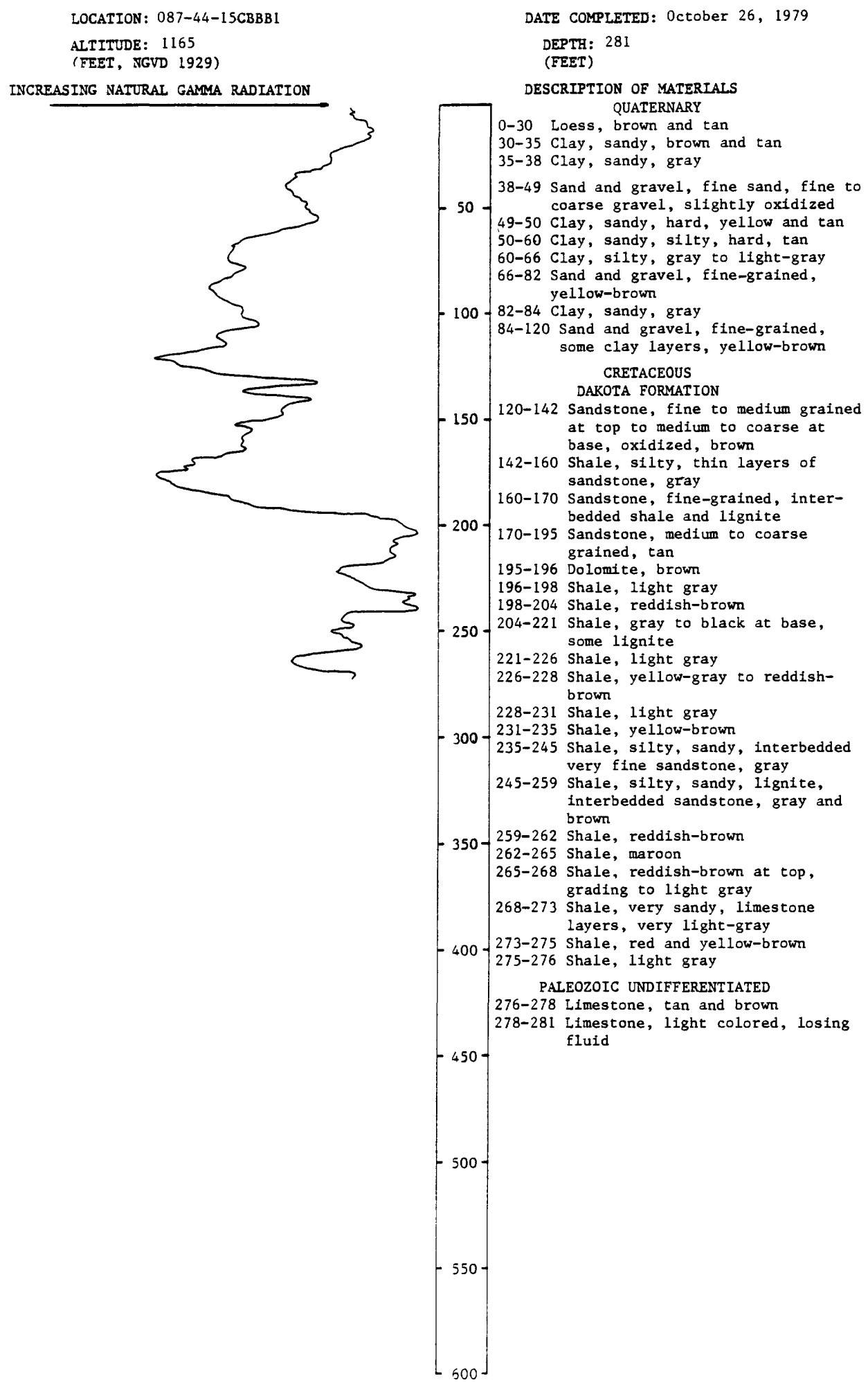


Table 2. Continued

IGS - D10

LOCATION: $87-41-05 C C C C 1$

ALTITUDE: 1344

(FEET, NGVD 1929)

INCREASING NATURAL GAMA RADIATION

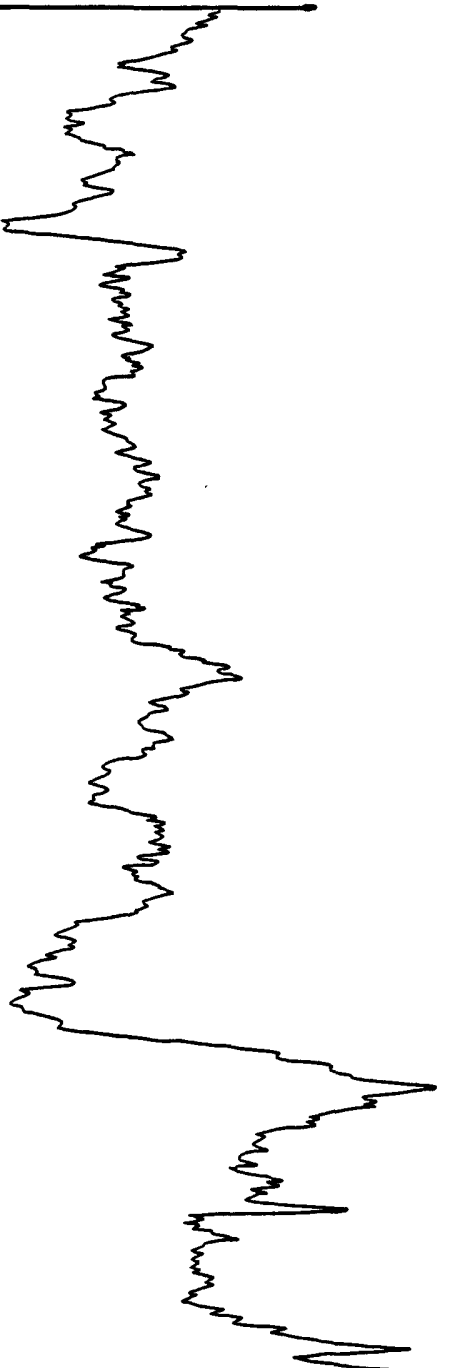

$\longrightarrow$

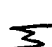

3

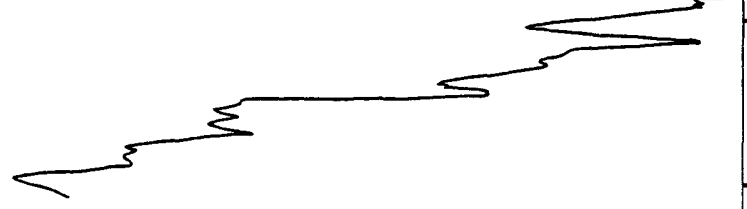

DATE COMPLETED: November 23, 1977

DEPTH: 510

(FEET)

DESCRIPTION OF MATERIALS

QUATERNARY

0-13 Loess, yellow-brown

13-15 Gumbo, brown and gray

15-16 Till, dark yellow-brown

16-26 Clay, silty, yellow-brown

26-31 Clay, silty, yellow-gray

50 - 31-40 T111, l1ght yellow-brown with some gray

40-68 Till, yellow-brown with boulders and grave 1

68-73 Sand and gravel, fine grained, yellow-brown

$100-$ 73-76 T111, yellow-brown

76-137 T111, blue-gray

150

137-155 Clay, some sand, gray with some gray-green clay

155-195 Clay or t111, yellow-gray

$-200$

195-241 Clay or till, blue-gray

241-273 Clay or till, silty, blue-gray CRETACEOUS DAKOTA FORMATION

273-280 Sandstone, very fine, silty, tan to gray

280-312 Sandstone, fine to coarse grained, cemented, gray-green

312-341 Shale, interbedded sandstone, gray to gray-green

341-355 Shale, maroon

355-401 Shale, maroon and light-gray

401-427 Shale, maroon, lignite, and sands tone

427-435 Sands tone

435-442 Shale, maroon and gray

450-442-452 Sandstone, fine to coarse gralned

452-470 Shale, maroon, some very thin sandstones

470-494 Sandstone, fine to medium grained

$500-$

PALEOZOIC UNDIFFERENTIATED

494-510 Limestone, 11ght tan and light gray 
Table 2. Continued

IGS - D16

LOCATION: $088-37-22 \mathrm{CCCD}$

ALTITUDE: 1320

(FEET, NGVD 1929)

INCREASING NATURAL GAMMA RADIATION

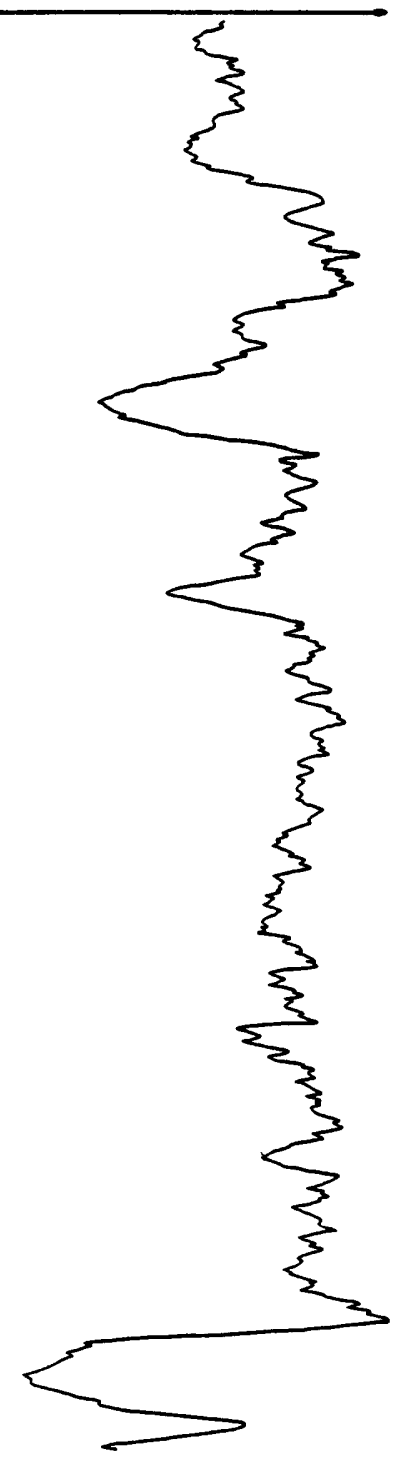

DATE COMPLETED: JUIY 10, 1978

DEPTR: 435

(FEET)

DESCRIPTION OF MATERIALS

QUATERNARY

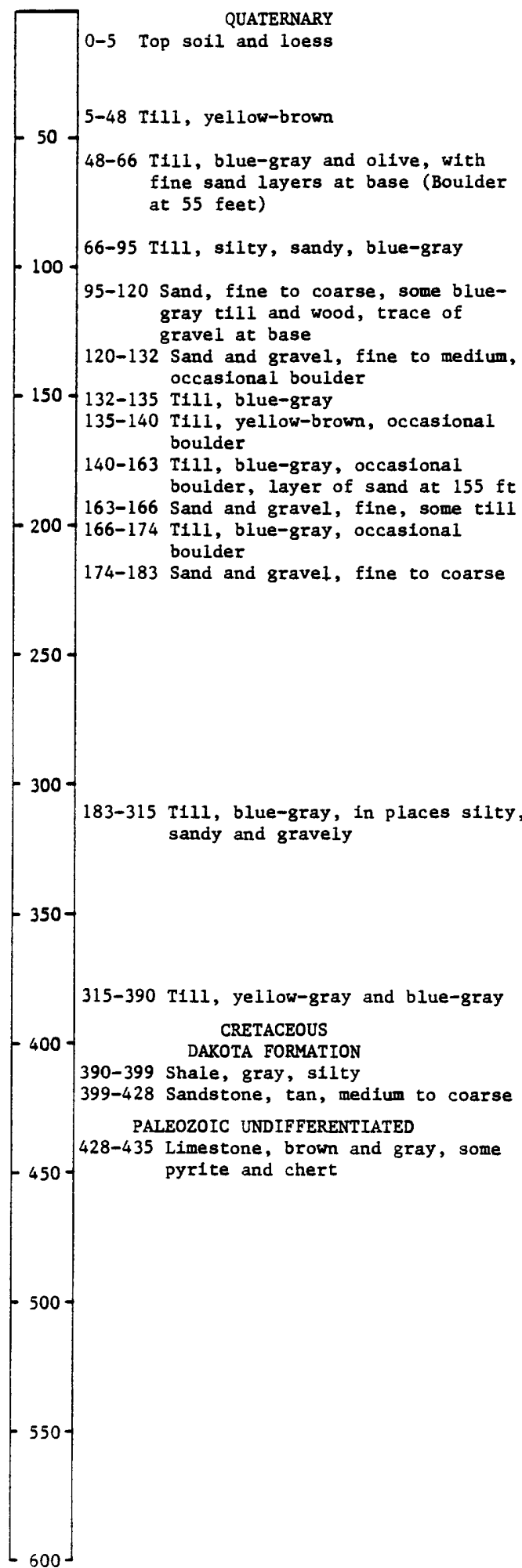


Table 2. Continued

IGS - D33

LOCATION: 088-44-06BAAB

ALTITUDE: 1340

(FEET, NGVD 1929)

INCREASING NATURAL GAMMA RADIATION

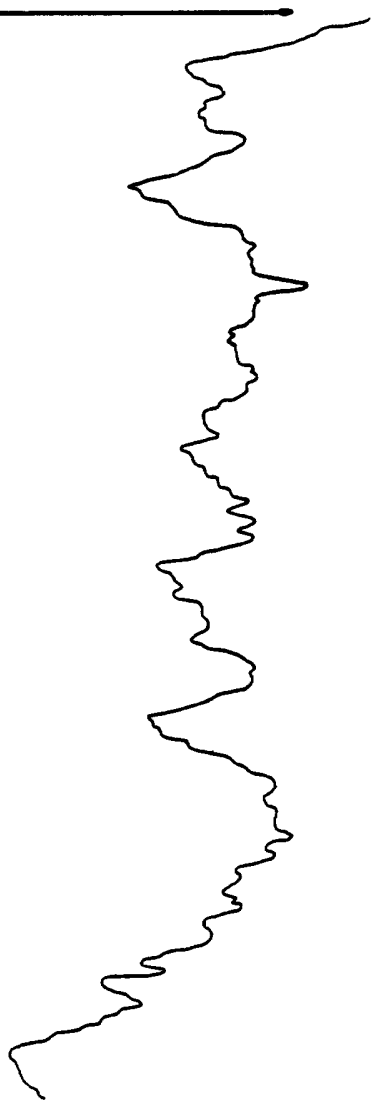

DATE COMPLETED: October 8, 1979

DEPTH: 521

(FEET)

DESCRIPTION OF MATERIALS

QUATERNARY

0-4 Loess, yellow-brown

4-15 Loess, dark brown to brown

15-40 Till, yellow-brown to yellow-gray with thin sand

40-47 Till, gray

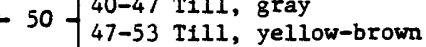

53-61 Sand and gravel, fine to medium, yellow-brown

61-67 Sand, fine with till layers

67-131 Till, gray with yellow, blue and ol1ve

131-135 Sand and gravel, fine to coarse, gray

135-140 Till, gray with sand and gravel layers

140-148 Sand and gravel, fine to coarse with till layers

148-168 Till, gravelly, blue-gray with sand and gravel layers

168-178 Sand and grave1, fine to coarse, gray

178-210 Till, blue-gray

-200- 210-221 Sand, fine to coarse, cemented, gray

CRETACEOUS

DAKOTA FORMATION

221-285 Sandstone, fine to medium, gray, some shale streaks

285-286 Dolomite or limestone

286-303 Sandstone, fine to medium, gray

303-320 Sandstone, fine to medium, tan

320-379 Sandstone, fine to coarse, tan

379-381 Shale, silty, gray

381-401 Sandstone, fine to medium, tan

350-401-409 Shale, silty, gray

409-415 Sandstone, coarse, brown, some shale

415-423 Sandstone, very coarse

423-425 Sandstone, coarse, hard, brown

425-430 Sandstone, coarse to medium, tan

- 400-430-432 Sandstone, medium, hard, brown

432-445 Sandstone, coarse, tan, gray shale at base

445-452 Sandstone, fine to medium with some shale, dolomite at base

452-455 Shale, very light gray with sandstone layers

455-470 Shale, silty, gray

470-471 Dolomite or Iimestone, brown

471-498 Sandstone, fine and shaly at top to fine to medium at base, tan

498-499 Shale, silty and sandy, light gray

499-506 Shale, sandy and silty, gray to reddish-brown

506-512 Shale, silty, sandy, very light gray

PALEOZOIC UNDIFFERENTIATED

550- 512-516 Limestone, fractured with some shale and sandstone

516-521 Limestone, fractured, coarse grained 
Table 2. Continued

IGS - D17

LOCATION: $089-38-36$ CBCC

ALTITUDE: 1445

(FEET, HGVD 1929)

INCREASING NATURAL GAMMA RADIATION

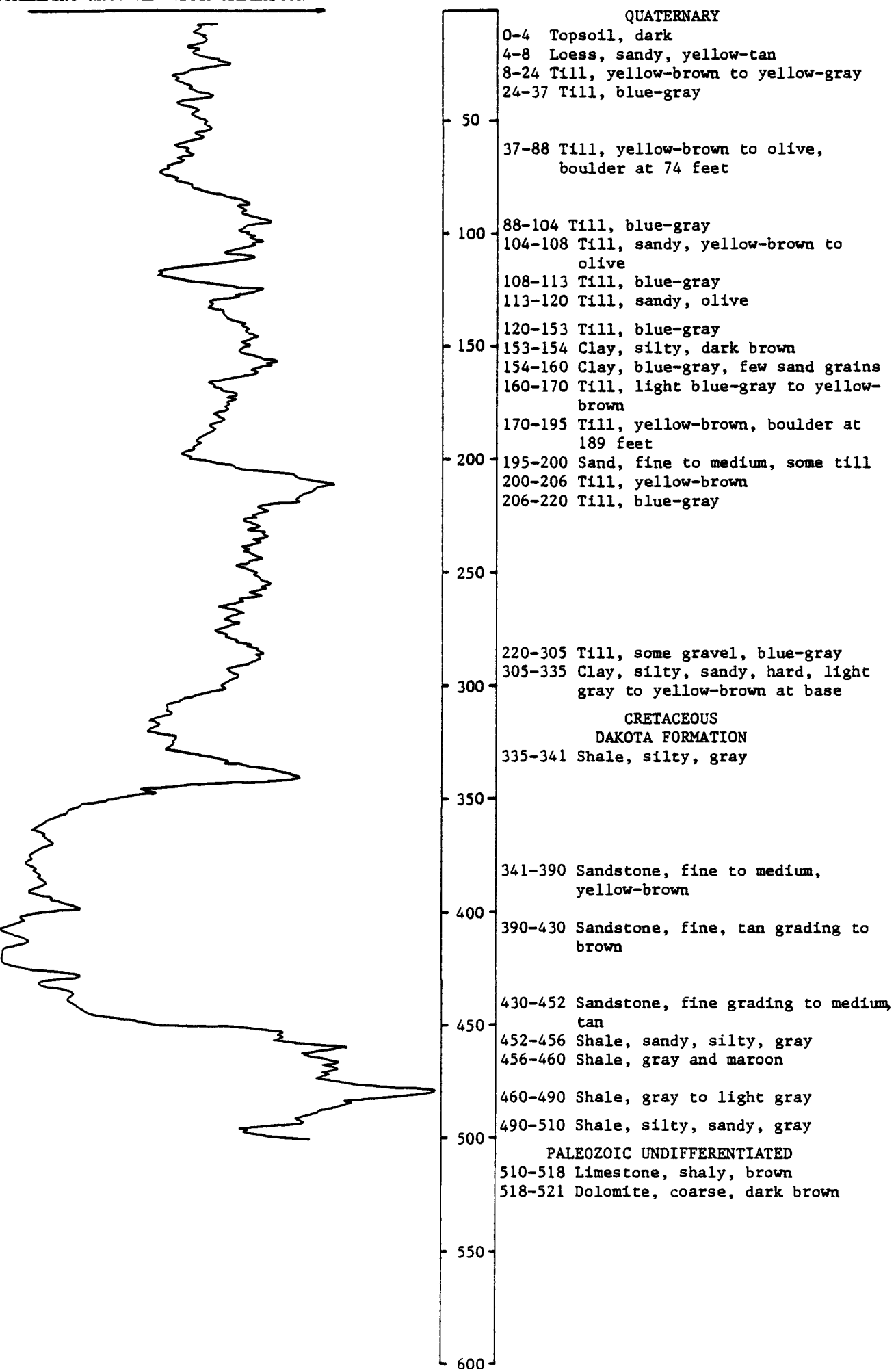


Table 2. Continued

IGS - D14

LOCATION: 089-39-14DDD

ALTITUDE: 1330

(FEET, NGVD 1929)
DATE COMPLETED: June 22, 1978

DEPTH: 375

(FEET)

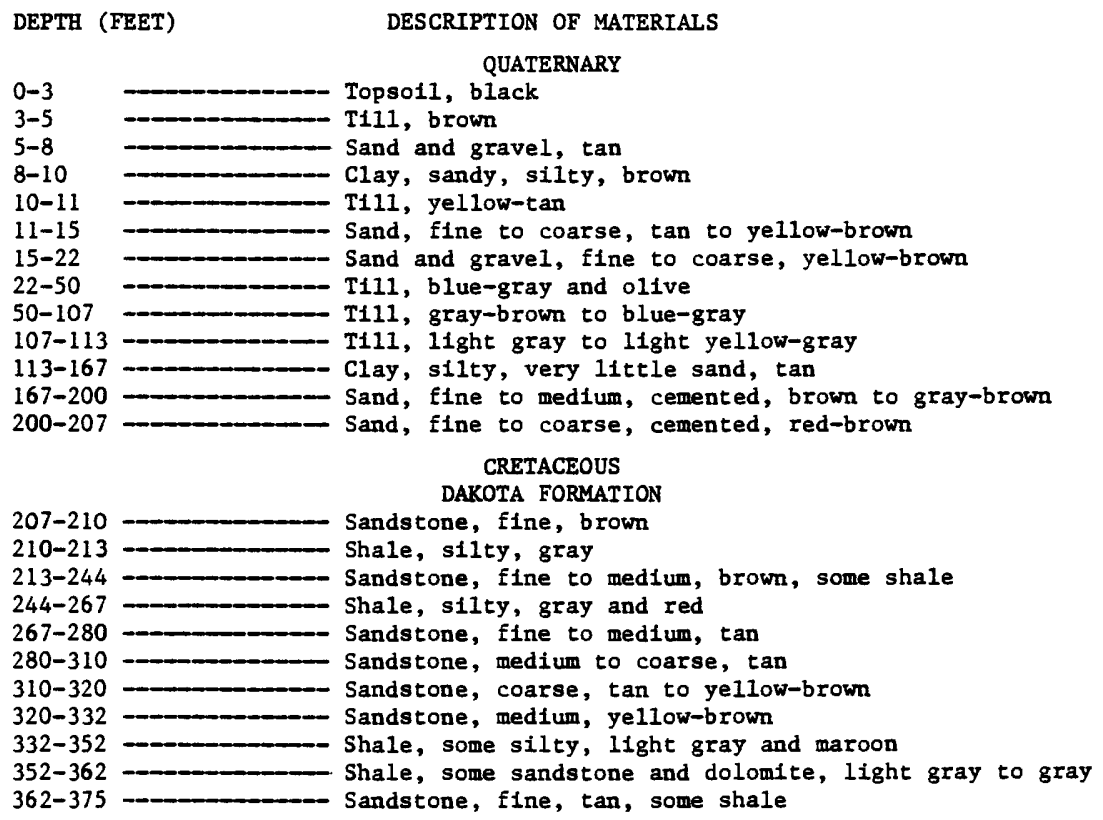

IGS - D32

LOCATION: 089-44-20DCDC

ALTITUDE: 1160

(FEET, IGGV 1929)

INCREASING NATURAI GAMYA RADIATION

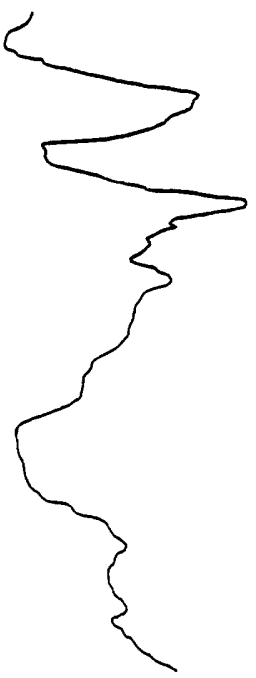

DATE COMPLETED: October 1, 1979

DEPTR: 221

(FEET)

DESCRTPTION OF MATERTALS QUATERNARY

0-5 Clay, sandy, silty, tan

5-15 Sand, fine to coarse, tan

15-32 Sand, fine to gravel, coarse tan

to yellow-brown

32-38 T111, yellow-brown grading to bluegray at base

38-50 Sand and fine gravel, tan to yellow-brown

50-70 Sand and medium gravel

70-71 Clay, tan

71-79 Sand, fine to coarse

79-81 Clay, tan

81-110 Sand and gravel, fine to medium, yellow-brown and tan

CRETACEOUS

DAKOTA FORMATION 
Table 2. Continued

IGS - D30

LOCATION: $089-46-36 \mathrm{BBDC1}$

ALTITUDE: 1268

(FEET, NGVD 1929)

\section{INCREASING NATURAL GAMMA RADIATION}

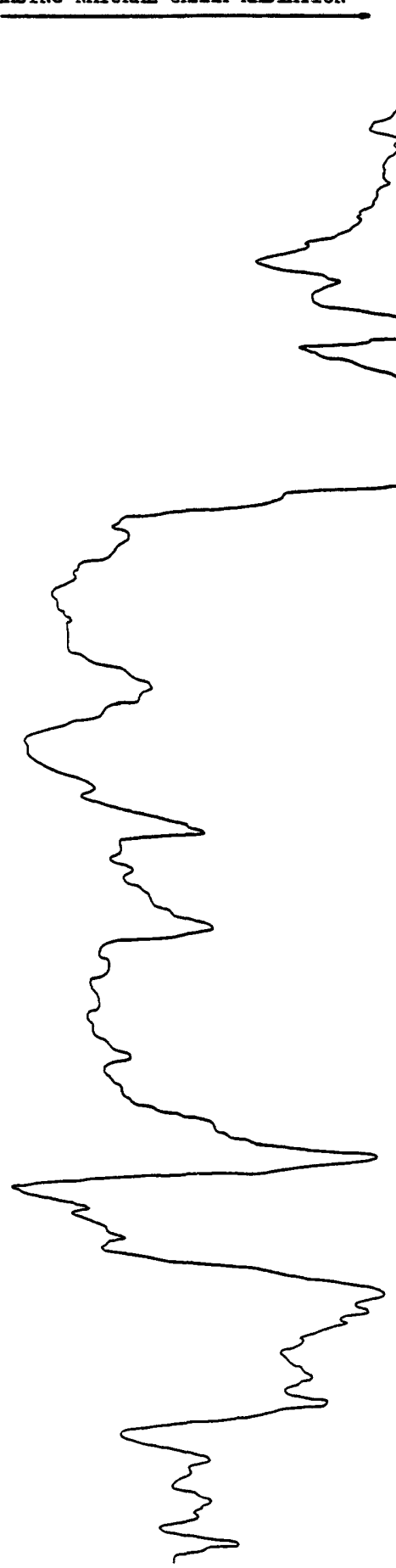

DATE COMPLETED: June 20, 1979

DEPTH: 557

(FEET)

DESCRIPTION OF MATERIALS

QUATERNARY

0-20 Loess, iron concretions, yellowbrown

20-50 Loess, iron concretions, yellowbrown, some gray, lighter colors at base

50-60 Loess, yellow-brown and gray

60-76 Loess, silty, blue and gray

76-79 Gravel and till, yellow-brown and gray

CRETACEOUS

DAKOTA FORMATION

79-88 Sandstone, fine to medium, 79-80 and 85-88 iron cemented

88-96 Shale, silty, tan to gray

- 150-96-105 Sandstone, very fine, some shale, light yellow-brown

105-111 Shale, silty, gray

111-115 Sandstone, fine to very fine, pyrite nodules, tan

115-175 Shale, silty, some pyrite and lignite, gray to brown

$-200$

175-245 Sandstone, fine to medium, tan

250

245-290 Sandstone, medium to coarse

$300-290$

290-320 Sandstone, fine to medium, tan 320-328 Sandstone, medium to coarse, tan 328-331 Shale, silty, light-gray

331-360 Sandstone, fine to medium, tan 350-360-373 Sandstone, medium to coarse, tan 373-374 Dolomite or limestone, brown

374-377 Sandstone, silty, shaly, gray

377-396 Sandstone, medium to coarse, tan

396-400 Limestone, fractured, some sand 400-400-405 Dolomite or limestone, coarse sandstone

405-501 Shale, silty, yellow, gray, maroon, some lignite and thin sandstone layers

501-512 Sandstone, medium to coarse

512-513 Dolomite, light tan

513-517 Shale, silty, gray

517-525 Shale, chert, limestone and sandstone all mixed

550- PALEOZOIC UNDIFFERENTIATED

525-535 Shale, sandy, some limestone and chert

535-539 Limestone, shaly

539-557 Limestone, some shale 
Table 2. Continued

IGS - D25

LOCATION: 090-38-16DDDD

ALTITUDE: 1365

(FEET, NGVD 1929)

INCREASING NATURAI GAMA RADLATION

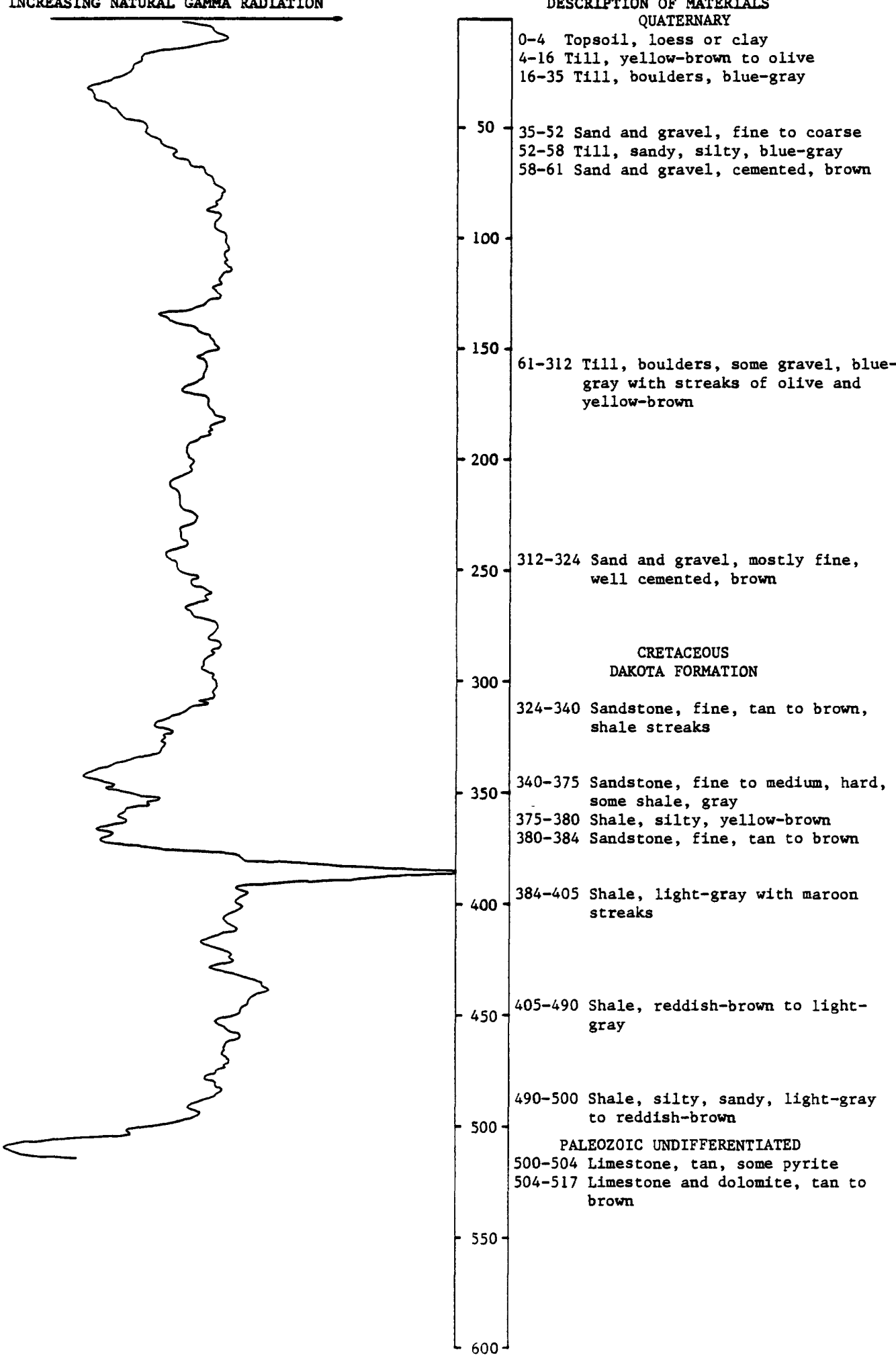

DEPTH: 517

(FEET)

DESCRIPTION OF MATERIALS

-4 Topsoil, loess or clay

4-16 Till, yellow-brown to olive

16-35 Ti11, boulders, blue-gray

52-58 T111, sandy, silty, blue-gray

-61 Sand and gravel, cemented, brown

61-312 Till, boulders, some gravel, bluegray with streaks of olive and yllow-brown

andstone, fine, tan to brown, shale streaks

Sandstone, fine to medium, hard,

375-380 Shale, silty, yellow-brown

80-384 Sandstone, fine, tan to brown

384-405 Shale, light-gray with maroon streaks

Shale, reddish-brown to lightgray

90-500 Shale, silty, sandy, light-gray to reddish-brown

500-504 Limestone, tan, some pyrite

Limestone and dolomite, tan to brown 
Table 2. Continued

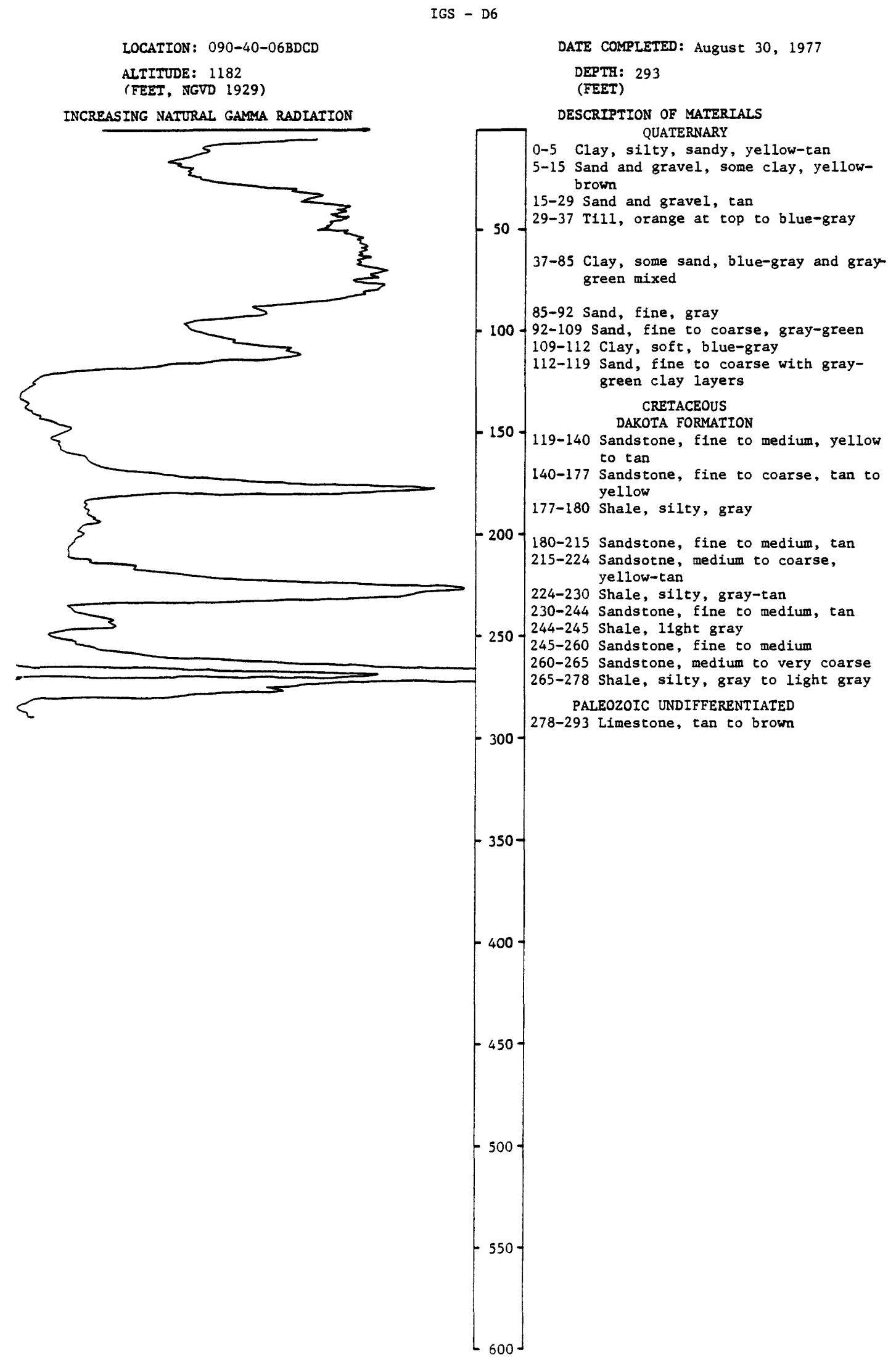


Table 2. Continued

IGS - D31

LOCATION: $090-45-28 \mathrm{CCD}$

ALTITUDE : 1300

(FEET, NGVD 1929)
DATE COMPLETED: September 12, 1979

DEPTH: $\quad 487$

(FEET)
DEPTH (FEET)

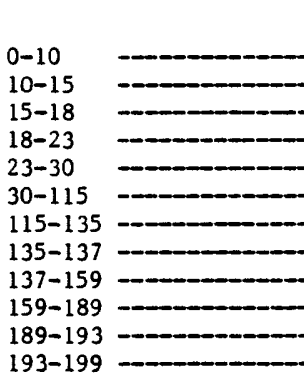

199-203

203-211

211-217

217-235

235-250

250-265

265-275

275-295

295-298

298-335

335-374

$374-378$

$378-380$

$380-383$

383-390

$390-480$

$80-$
$80-$
DESCRIPTION OF MATERIALS

QUATERNARY

- Topsoil and loess with iron concretions, yellow-tan

Loess, dark yellow-brown

Loess, yellow-brown, sandy at bottom

Till, dark brown to yellow-brown

Till, yellow-gray to olive

Till, silty, blue-gray

- Sand and grave1, coarse, boulders, yellow-brown

- Clay, silty, tan

Sand and gravel, fine to medium, yellow-brown

Till, gray

- Sand, fine to medium, gravel, gray

Clay, gray

CRETACEOUS

DAROTA FORMATION

PALEOZOIC UNDIFFERENTIATED

480-487 - Limestone and chert, yellow-brown and tan 
Table 2. Continued

IGS - D28

LOCATION: 091-39-01ADAD1

ALTITUDE: 1370

(FEET, NGVD 1929)

INCREASING NATURAL GAMA RADIATION

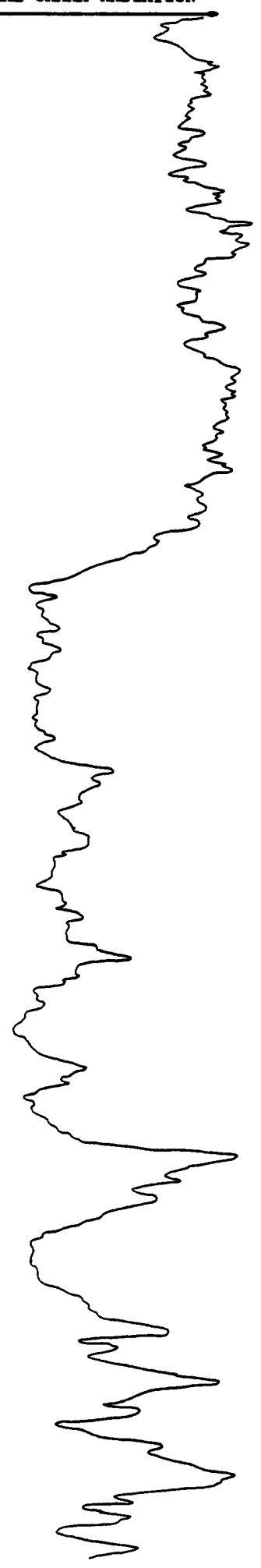

DATE COMPLETED: June 6, 1979

DEPTH: 1545

(FEET)

DESCRIPTION OF MATERIALS



- $50-\begin{array}{ll}5-14 & \begin{array}{l}\text { QUATERNARY } \\ \text { brown }\end{array} \\ \text { 14-80 Till, sand and gravel, very light } & \text { gravel, very light }\end{array}$ yellow

80-90 Till, very light brown, gray

90-96 Till, sandy, pebbles, light gray

96-100 Till, very light yellow-orange

$100-$

100-120 Till, very light yellow-orange to light olive-gray

$150-120-170 \mathrm{Till}$, sand and gravel, light medium gray

170-215 Till, sand and gravel, very light orange-brown

200-215-225 Sand, fine to very coarse, calcareous CRETACEOUS DAKOTA FORMATION

225-241 Sandstone, very fine to fine, some clay, dark gray to medium brown

241-253 No sample

253-273 Sandstone, very fine to fine, light gray to light orange

273-290 Sandstone, very fine to medium, 300 red-brown

290-293 No sample

293-303 Sandstone, coarse, dark red-brown

303-343 Sandstone, very fine to fine,

- $350-$ some medium, micaceous, yelloworange

343-363 Sandstone, fine to medium, partly hematite cement, orange-yellow

363-393 Sandstone, fine to medium, clay bands

- 400-393-413 Clay, some sandstone, very light gray

413-443 Sandstone, very fine to medium, cemented, some clay, gray

443-457 Clay, white to pale gray, some sand

- 450-457-473 Clay, sandy, some chert, white to light olive-gray PALEOZOIC MISSISSIPPIAN

473-508 Dolomite, porous, Eossiliferous,
508-529 Dolomite, argillaceous, sand filling fractures at top, gray to green

- 550-529-537 Shale, dolomitic, green

537-544 Dolomite, brecciated, shale in bottom 2 feet

544-593 Limestone, fractured and shale, gray-green 
Table 2. Continued

IGS - D28 (Continued)

INCREASTNG NATURAL GAMMA RADIATION

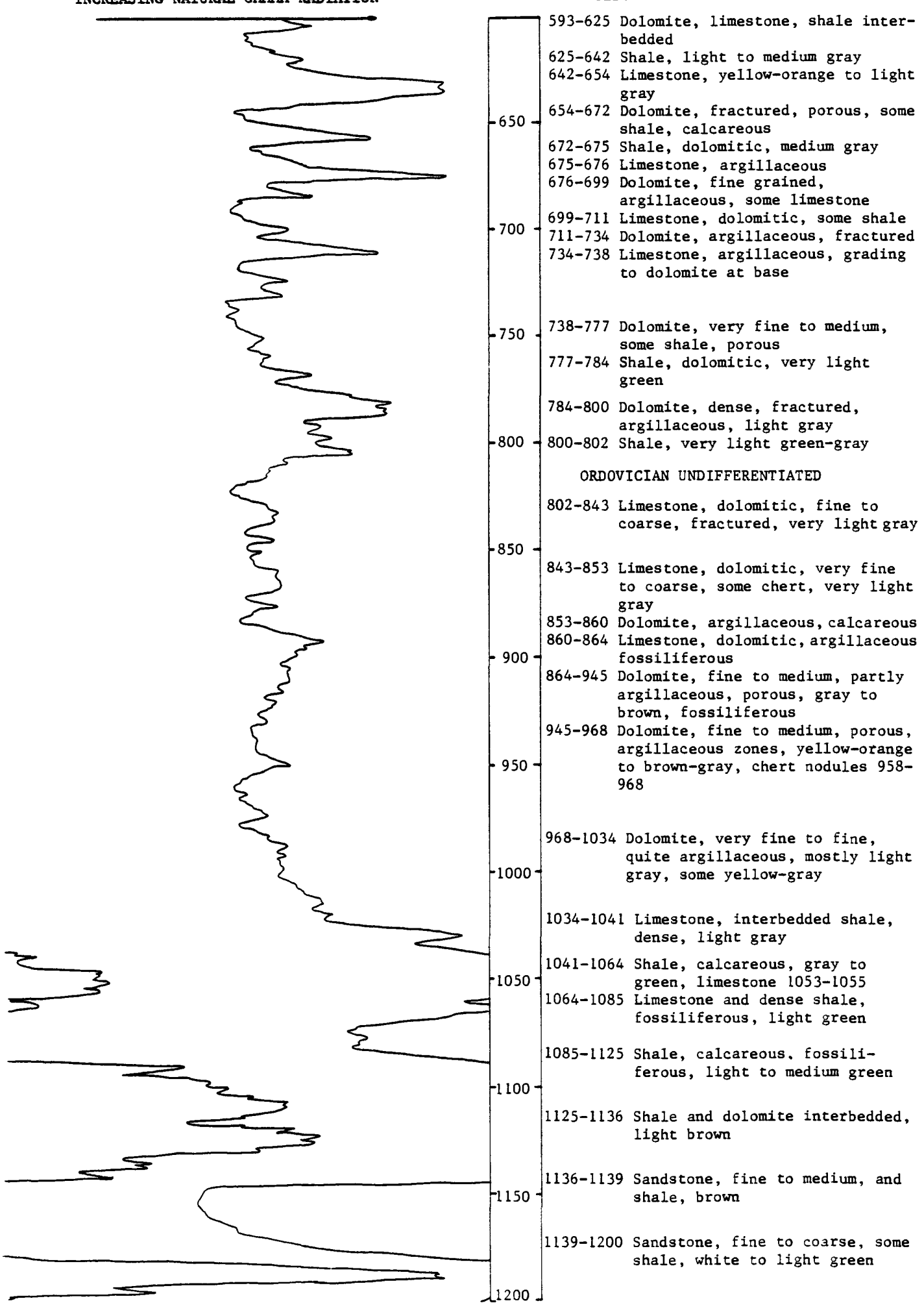

42-654 Iimestone, yellow-orange to light gray

72-675 Shale, dolomitic, medium gray

75-676 Limestone, argillaceous

711-734 Dolomite, argillaceous, fractured

34-738 Limestone, argillaceous, grading to dolomite at base Dolomite, very fine Shale, dolomitic, very ligh

DESCRIPTION OF MATERIALS 
Table 2. Continued

IGS - D28 (Continued)

INCREASING NATURAL GAMMA RADIATION

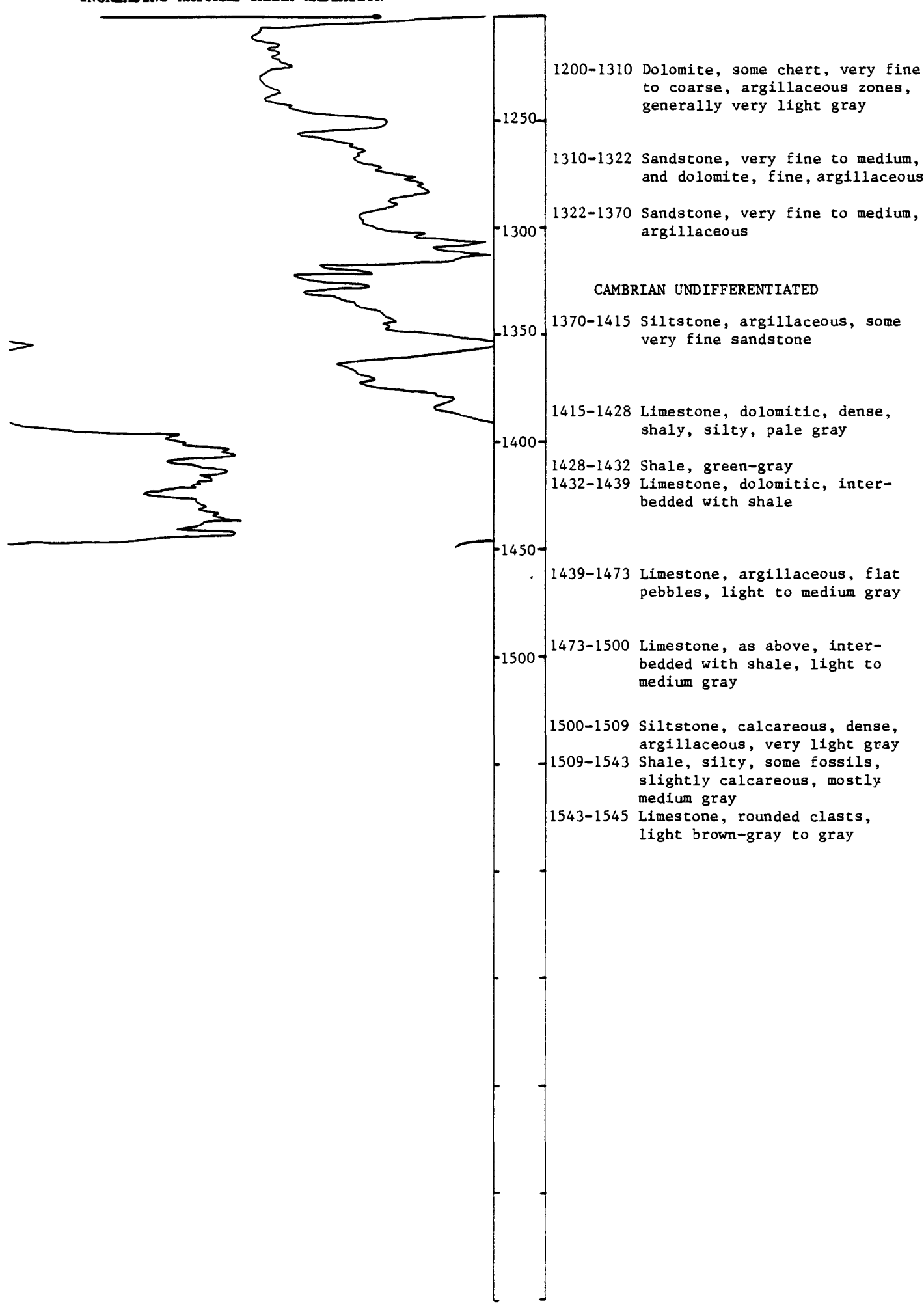

DESCRIPTION OF MATERIALS 
Table 2. Continued

IGS - DI1

LOCATION: 091-42-16DDDD

ALTITUDE: 1320

(FEET, NGVD 1929)

INCREASING NATURAL GAMA RADIATION

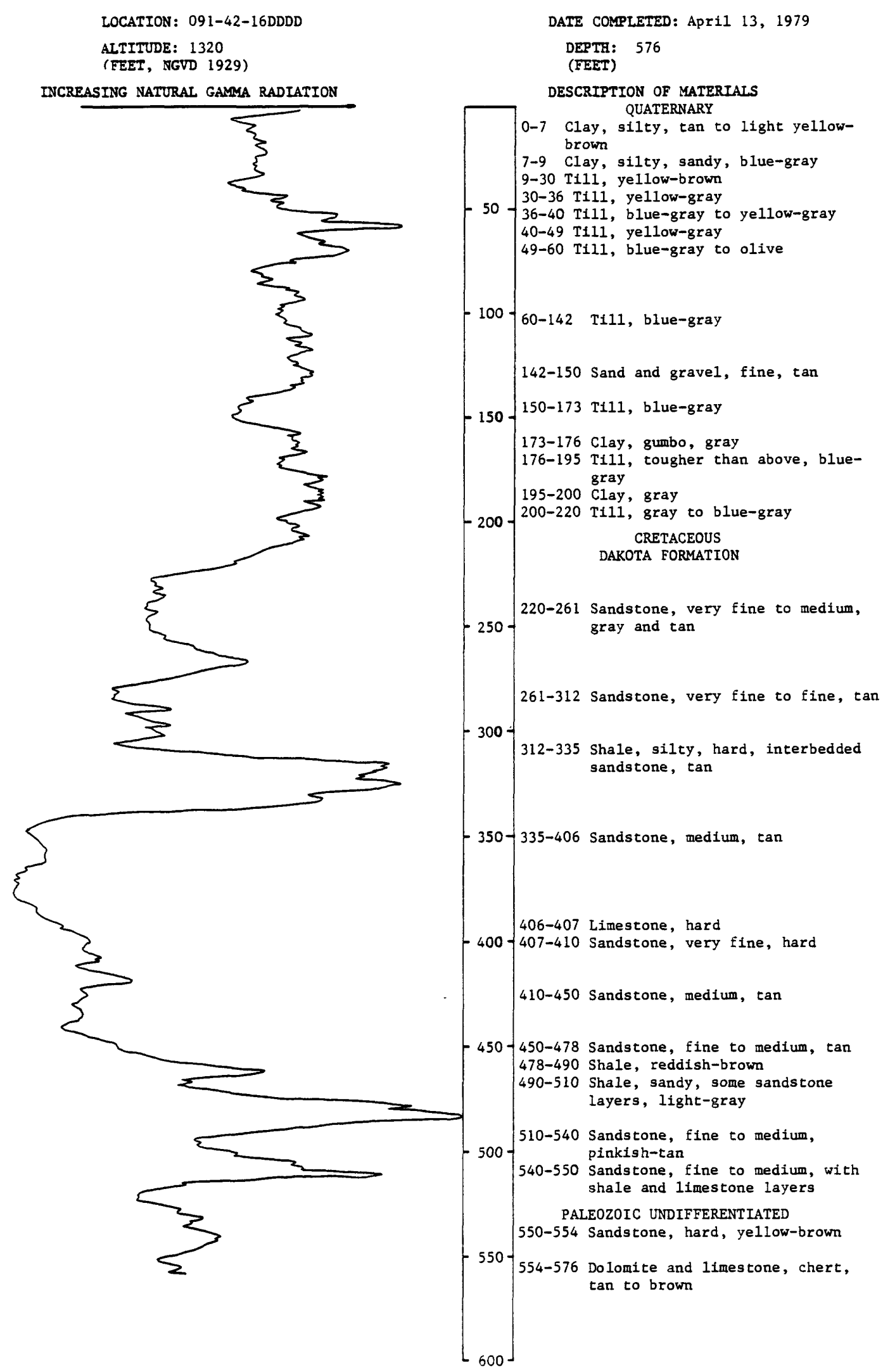

DATE COMPLETED: April 13, 1979

DEPTH: 576

(FEET)

DESCRIPTION OF MATERIALS

0-7 Clay, silty, tan to light yellow-

7-9 Clay, silty, sandy, blue-gray

9-30 Till, yellow-brown

$36-40 \mathrm{~T} i 11$, blue-gray to yellow-gray

40-49 Till, yellow-gray

49-60 Till, blue-gray to olive

$-100$

142-150 Sand and grave1, fine, tan

I11, blue-gray

73-176 Clay, gumbo, gray gray

195-200 Clay, gray

200 200-220 Till, gray to blue-gray

220-261 Sandstone, very fine to medium, gray and tan

261-312 Sandstone, very fine to fine, tan

312-335 Shale, silty, hard, interbedded sandstone, tan 
Table 2. Continued

IGS - D21

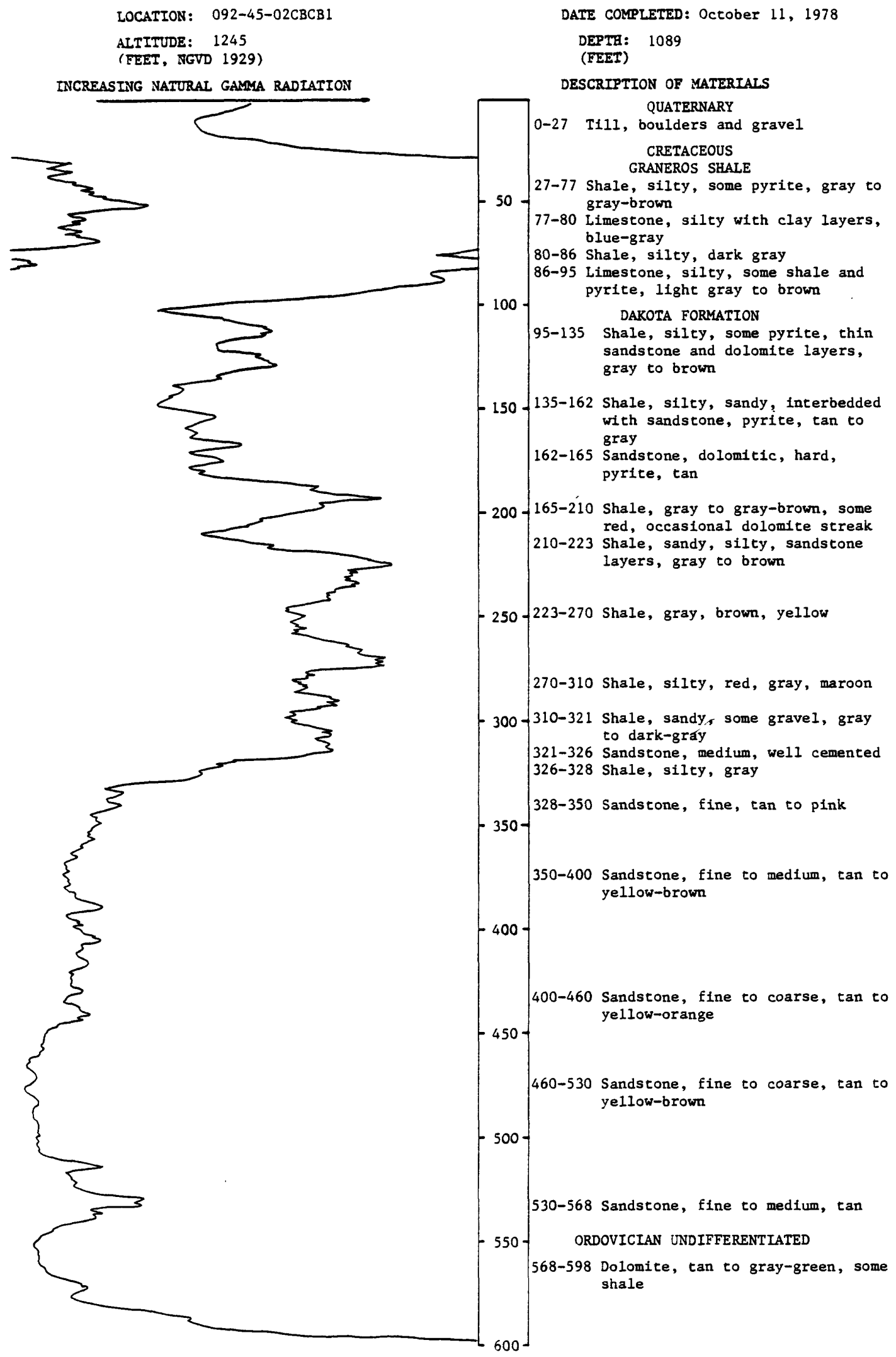


Table 2. Continued

IGS - D21 (Continued)

INCREASING NATURAL GAMM RADIATION

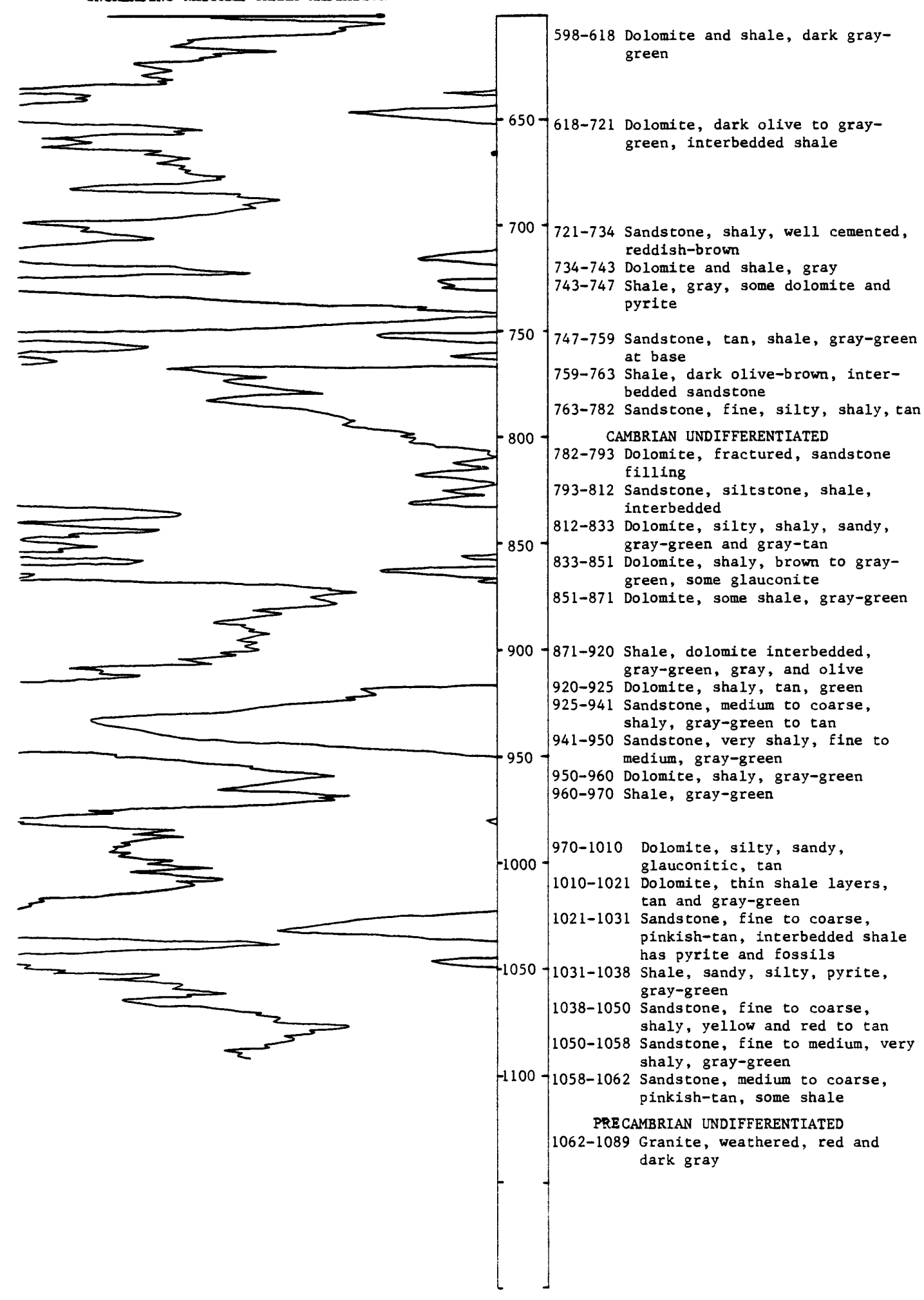


Table 2. Continued

IGS - D 35

LOCATION: 092-48-06DDDA1

ALTITUDE: 1282

(FEET, IGVD 1929)

INCREASING NATURAL GAMA RADIATION

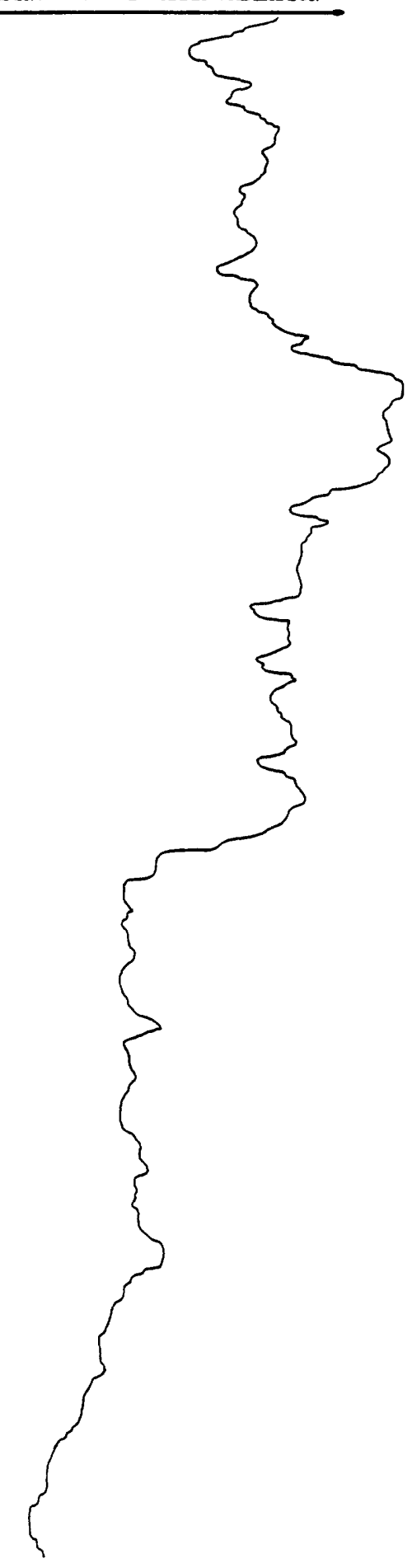

DATE COMPLETED: November 1979

DEPTR: 581

(FEET)

DESCRIPTION OF MATERIALS

$0-10$ QUATERNARY

10-35 Sand and gravel, fine to medium, tan to pink

35-36 Clay, tan-gray

36-42 Sand and gravel, tan to pink

- 50 -42-72 Clay, some sandy or silty, tan to gray

72-78 Clay, silty, yellow-brown

78-95 Clay, silty, sand, gray

95-106 Sand, fine to medium, some cemented

- 100 -106-110 Clay, sandy, blue-gray, possibly till

-150- $\begin{gathered}\text { CRETACEOUS } \\ \text { GREENHORN LIMESTONE } \\ 110-130 \begin{array}{l}\text { Limestone, shaly, fossiliferous, } \\ \text { dark colored }\end{array}\end{gathered}$

$-150-$ dark colored

130-175 Shale, silty, some siltstone, Shale, silty, some
pyrite, dark gray DAROTA FORMATION

- 200-175-216 Shale, silty, sandy, siltstone, pyrite, dolomite at 203 feet

216-218 Coal, very dark shale

218-228 Sandstone, fine, pyrite, interbedded shale

228-285 Shale, sandy, silty, some thin dolomite and siltsone beds, pyrite, trace of lignite

285-302 Shale, silty, gray to blue-gray

-300-302-303 Sandstone, fine to medium

303-314 Shale, silty, some dolomite

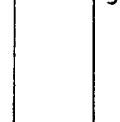

$350-$

314-448 Sandstone, fine to medium, some coarse, tan

$-400-448-480$ shale, sandy, silty, some sand-

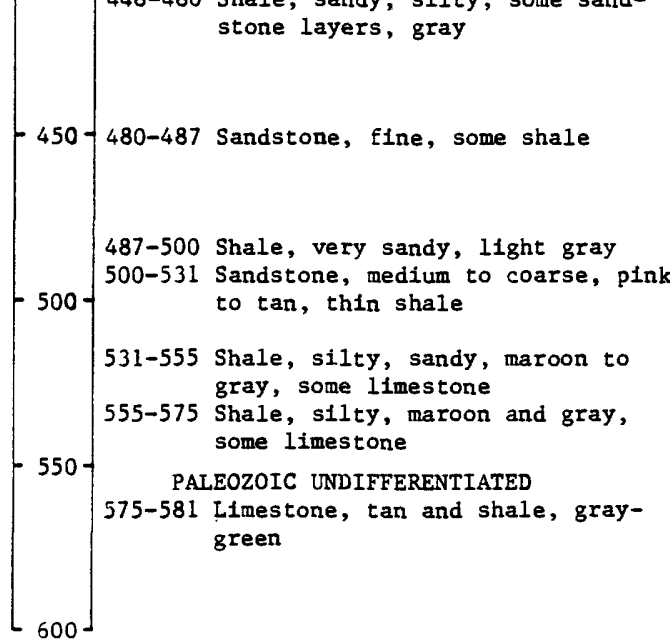


Table 2. Continued

IGS - D27

LOCATION: 093-35-19DCBB

ALIITUDE: 1322

(FEET, NGVD 1929)

INCREASING NATURAL GAMMA RADIATION

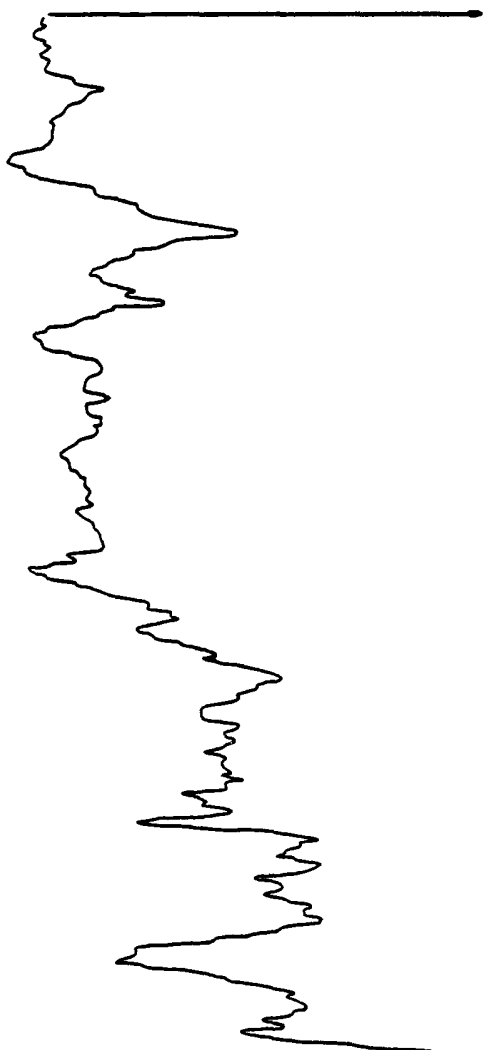

DATE COMPLETED: May 30, 1979

DEPTH: 381

(FEET)

DESCRIPTION OF MATERIALS

QUATERNARY

0-5 Clay, sandy, topsoil

5-30 Sand and gravel, fine to coarse, brown to yellow-brown

30-46 T111, gravelly, blue-gray

46-55 Sand and gravel, fine, yellow-brown

55-57 T111, blue-gray

57-67 Sand and gravel, fine, yellow-brown

67-75 Till, yellow-brown

75-86 T111, some gravel, blue-gray

86-89 Sand and gravel, fine, yellow-brown

$-100$

89-161 Ti1l, boulders, gravel, blue-gray

$-150-$

161-171 Ti11, yellow-brown

171-174 Sand and gravel, yellow-brown

174-220 Till, gravelly, yellow-brown to

yellow-gray

220-243 Till, some gravel, blue-gray

CRETACEOUS

DAKOTA FORMATION

243-249 Sandstone, tan, some shale

249-256 Shale, silty, light gray

256-285 Shale, maroon to red-brown

285-290 Sandstone, fine grading to coarse

290-318 Shale, silty, some sand, light gray to red-brown

318-325 Sandstone, fine to medium, shale streaks, lignite

325-341 Shale, sandstone streaks, silty, very light gray

PALEOZOIC UNDIFFERENTIATED

341-381 Chert and dolomite, tan 
Table 2. Continued

IGS - D12

$\begin{array}{ll}\text { LOCATION: } 093-44-36 \mathrm{CCC} \\ \text { ALTITUDE: } & 1350\end{array}$

(FEET, NGVD 1929)
DATE COMPLETED: Apri1 26, 1978

DEPTH: 645

(FEET)
DEPTH (FEET)

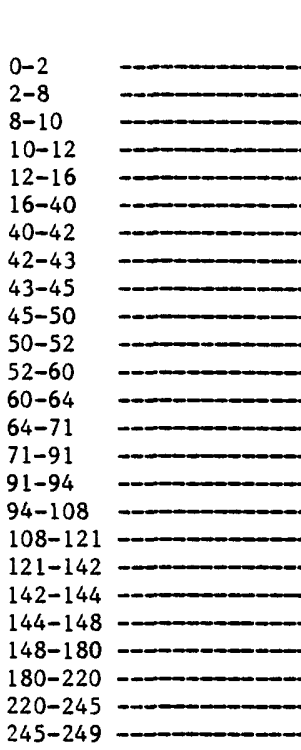

DESCRIPTION OF MATERIALS

QUATERNARY

Topsoil

Loess, tan to yellow-brown

Sand and gravel, till mixed, yellow-brown

Till, yellow-brown

Clay, gumbo, gray

Till, yellow-brown

Sand and gravel, fine to medium, yellow-brown

Till, yellow-brown

Sand and gravel, till mixed, iron oxide

Till, gravelly, yellow-brown and gray

Sand and gravel, fine to medium, yellow-brown

Iill, gravelly, olive and blue-gray

Sand and gravel, till mixed

Sand, fine to coarse, cemented, yellow-tan

Till, blue-gray

Sand and gravel, fine to coarse, gray

Till, blue-gray, sand and gravel 101-102

Clay, sandy, gray-green to gray-brown

Sandy, very fine to fine, silty, gray

Clay, gray-green

Sand, fine, silty, tan and gray

Clay, silty, some sand layers, gray-green

Gravel, sand, wood, some cemented

Sand, fine to coarse, cemented, gray

Gravel, sand, clay, pyrite, boulders

CRETACEOUS

DAKOTA FORMATION

249-252

252-261

261-262

262-265

265-304

$304-316$

316-343

343-370

$370-430$

430-450

$450-507$

507-641

Limestone, sandy, hard, brown

Shale, silty, gray

Limestone, hard, brown

Sandstone, fine and shale, silty, gray

Shale, silty, some sandstone layers, brown to gray

Sandstone, fine, tan, some shale, gray

Shale, silty, gray, interbedded sandstone, fine, tan

Sandstone, fine, tan, layers of shale, silty, gray

Shale, silty, light gray, some sandstone streaks

Sandstone, fine to medium, tan

Sandstone, medium to coarse, some fine, tan

Sandstone, fine to medium, tan, some shale

PALEOZOIC UNDIFFERENTIATED

641-645

Limestone, coarse, tan and white chert 
Table 2. Continued

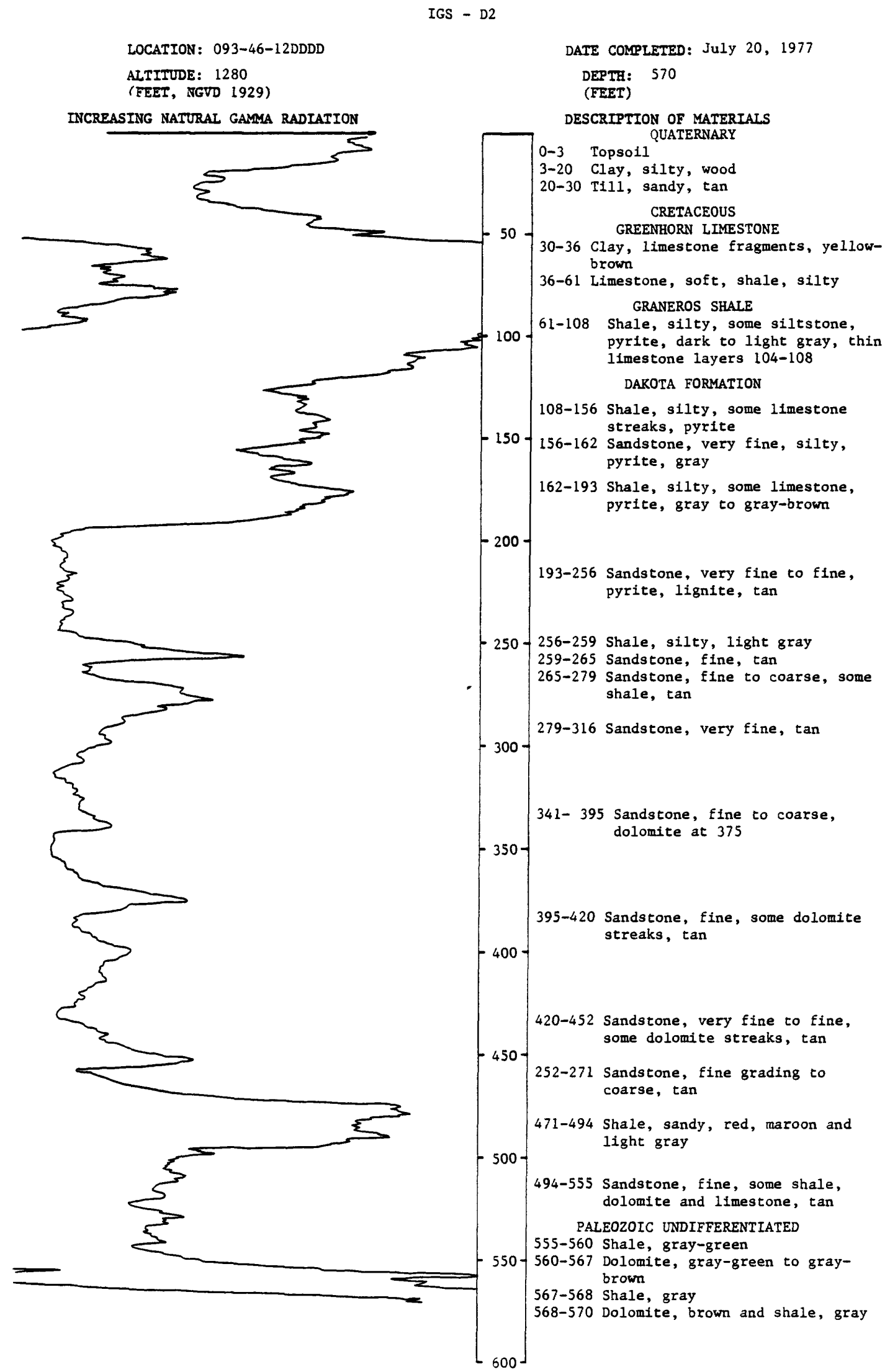


Table 2. Continued

IGS - D18

LOCATION: 094-47-35AAAB

ALIITUDE: 1305

(FEET, IGGD 1929)

INCREASING NATURAL GAMMA RADIATION
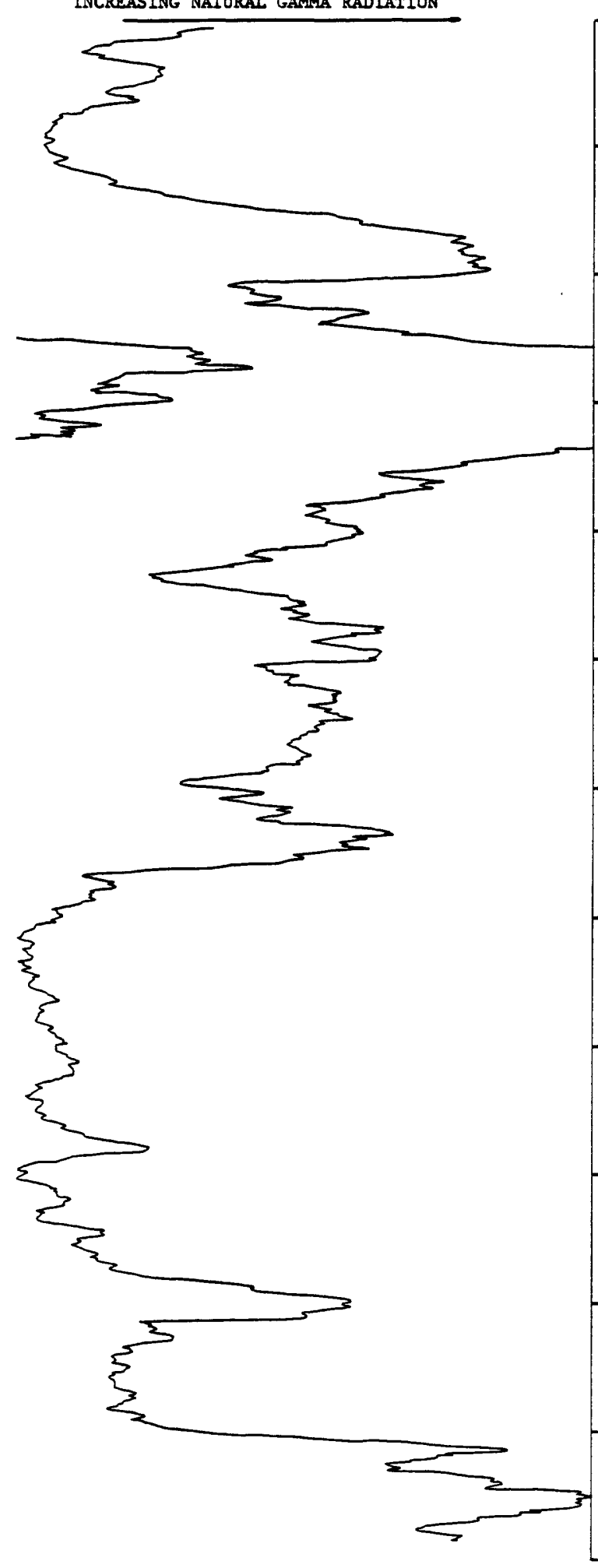

DATE COMPLETED: July 30, 1978

DEPTH: 601

(FEET)

DESCRIPTION OF MATERIALS

QUATERNARY

0-10 Clay, tan to brown

10-28 Sand, some silty clay, tan

28-34 Sand and gravel, fine to boulders

34-37 Till, sandy, silty, yellow to bluegray

37-75 Sand and grave1, medium to coarse, yellow-brown

CRETACEOUS

CARLILE SHALE

$-100$

75-102 Shale, silty, gray to blue-gray GREENHORN LIMESTONE

102-113 Limestone, brown to dark brown

113-128 Shale, hard, calcareous, brown and dark gray

GRANEROS SHALE

128-170 Shale, silty, pyrite, gray-brown DAKOTA FORMATION

170-190 Shale, siltstone and Iimestone, pyrite, gray

200

190-215 Shale, silty, sandy, pyrite, gray

215-221 Sandstone, very fine, pyrite, tan

221-330 Shale, sandy, silty, some pyrite and lignite, tan to gray

330-360 Sandstone, very fine to fine, tan

360-381 Sandstone, fine to medium, tan

381-400 Sandstone, medium, tan

400-420 Sandstone, fine, tan

420-460 Sandstone, fine to medium, tan

460-494 Sandstone, medium to coarse, tan, dolomite at 483 feet

494-505 Shale, silty, gray to light gray

505-550 Sandstone, very, fine to medium at base, gray to tan

PALEOZOIC UNDIFFERENTIATED

550-572 Shale, maroon, yellow, gray, and green

572-581 Shale, sandy, red-brown

581-601 Limestone and shale, tan, graygreen, red-brown 
Table 2. Continued

IGS - D4

LOCATION: 095-39-04ABCB

ALTITUDE: 1390

(FEET, ITGVD 1929)

INCREASING NATURAL GAMMA RADIATION

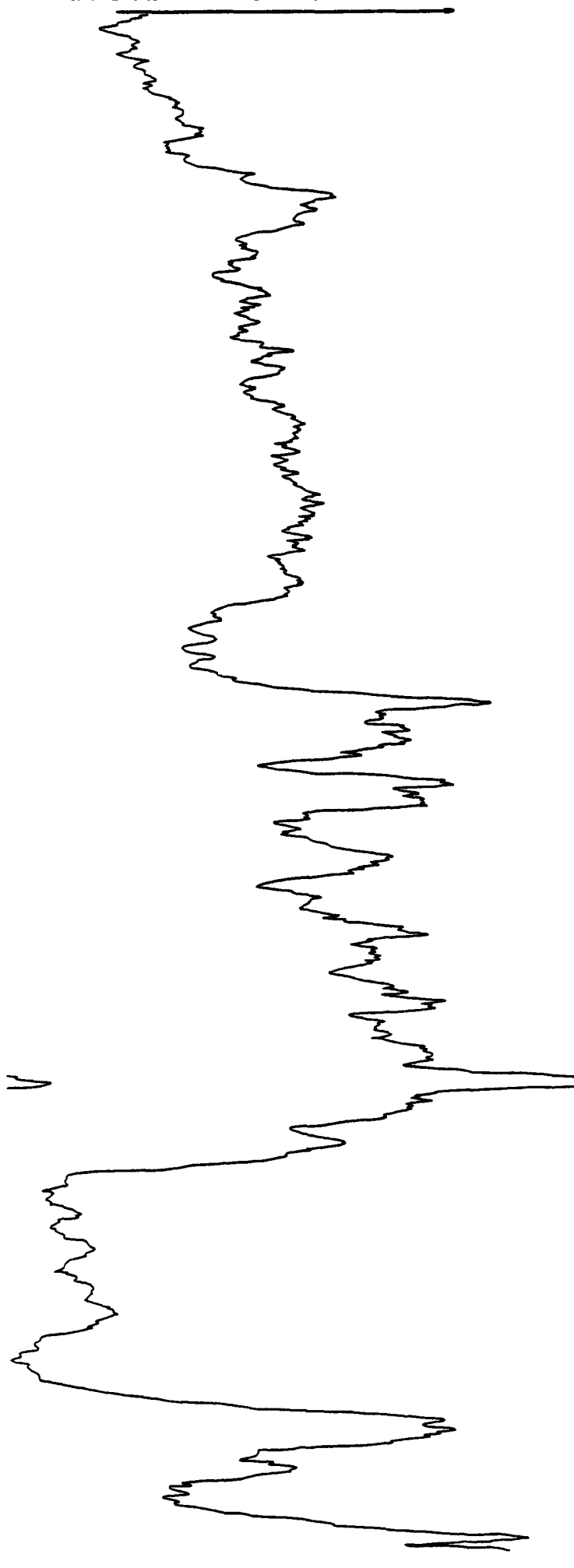

DATE COMPLETED: August 11, 1977 DEPTH: 620 (FEET)

DESCRIPTION OF MATERIALS

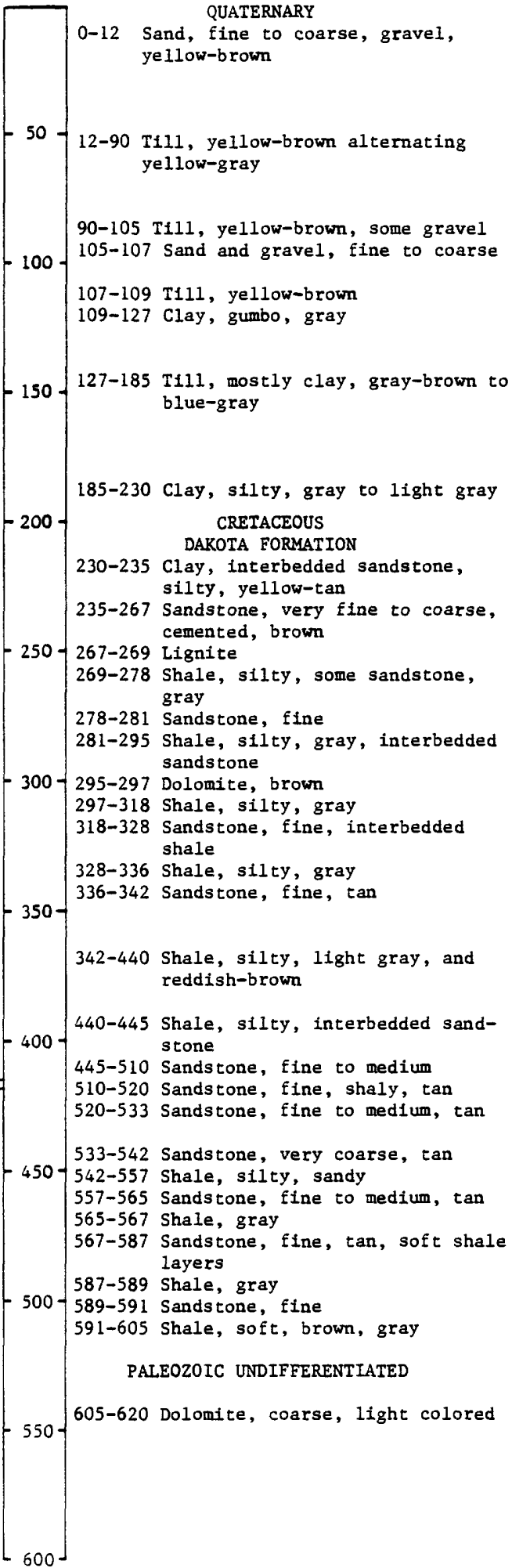


Table 2. Continued

IGS - D37

LOCATION: 096-34-24BBB

ALTITUDE: 1315

(FEET, NGVD 1929)

INCREASING NATURAL GAMA RADIATION

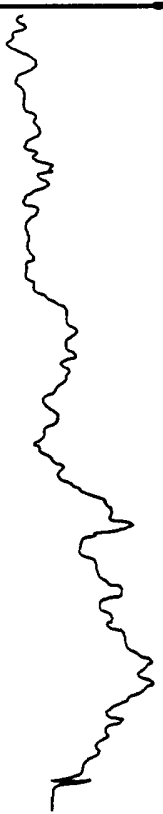

DATE COMPLETED: November 1979

DEPTH: 501

(FEET)

DESCRIPTION OF MATERIALS

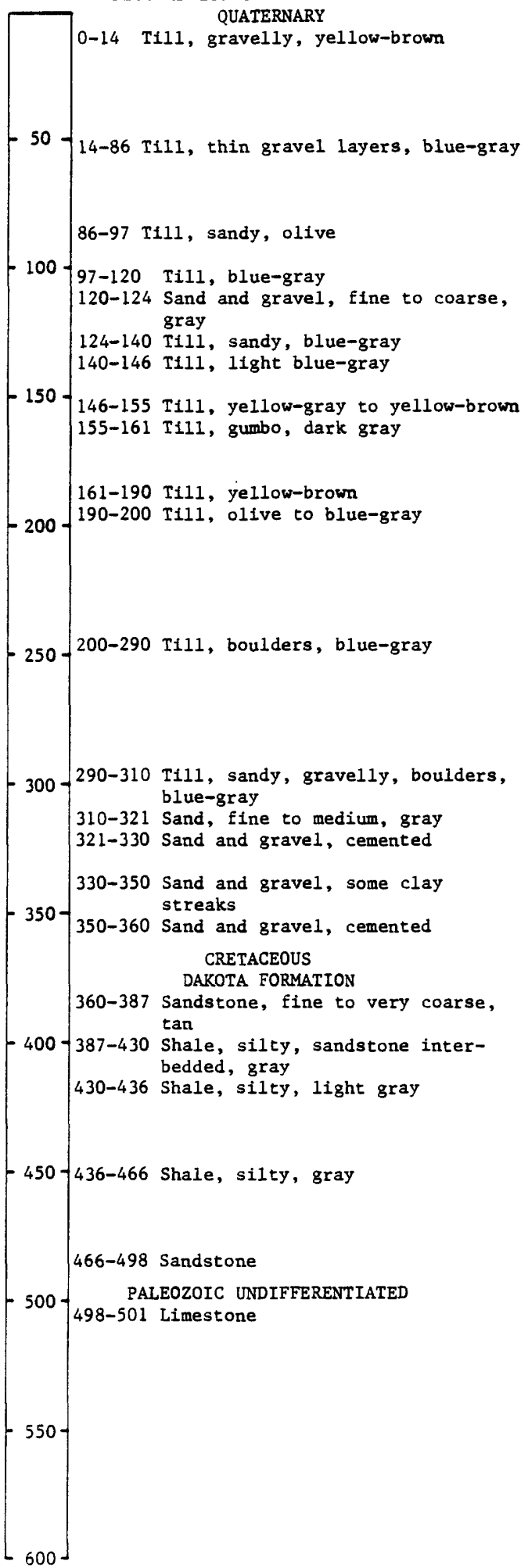


Table 2. Continued

IGS - D41

LOCATION: 096-40-05DDDA

ALTITUDE: 1560

(FEET, NGVD 1929)

INCREASING NATURAL GAMMA RADIATION

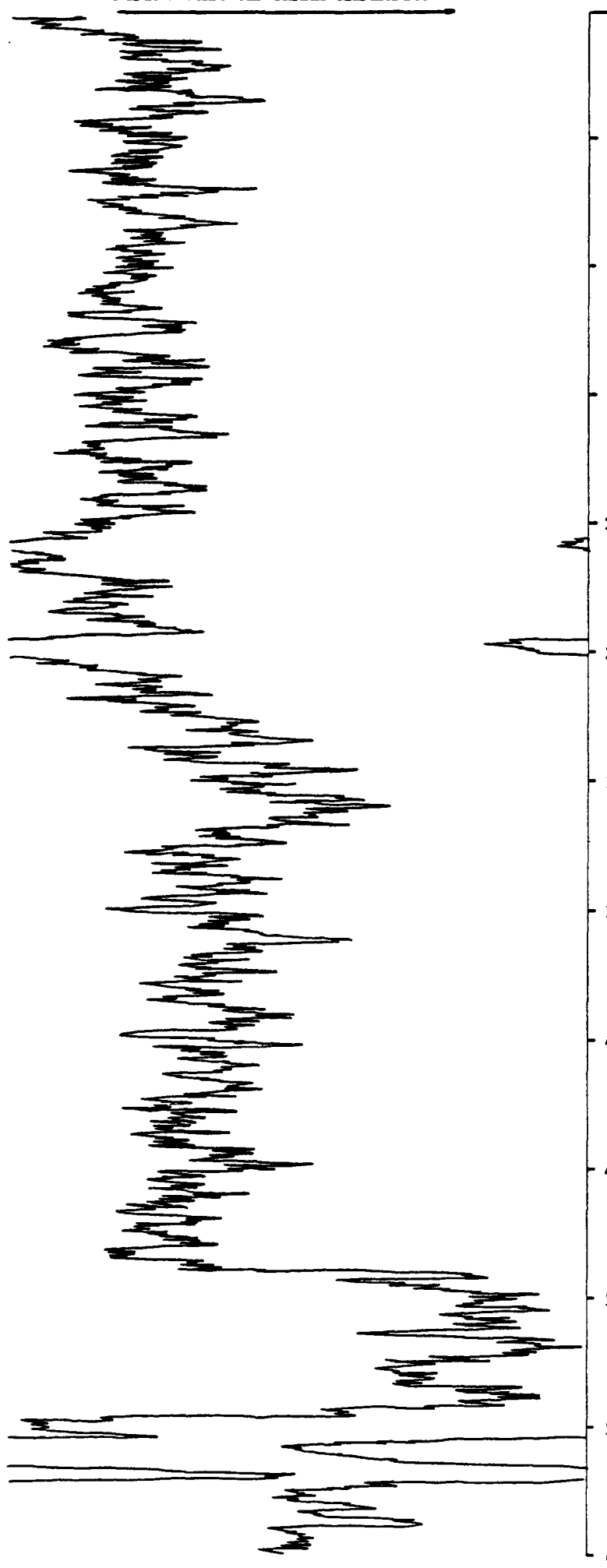

DATE COMPLETED: June 1980

DEPTE: 704

(FEET)

DESCRIPTION OF MATERIALS

QUATERNARY

0-35 Till, yellow-brown to yellow-gray

35-190 Till, some boulders, blue-gray

190-208 Till, gravelly, blue-gray

208-211 Sand and gravel, fine to medium, gray

211-214 Clay, silty, brown

214-218 Till, sandy, light blue-gray

218-221 Sand and gravel, fine to coarse, mostly fine, gray

221-226 Till, sandy, light blue-gray

226-234 Till, thin gravel layers, yellow-

brown

234-236 Till, sandy, gray

236-244 Till, yellow-brown

244-252 Sand, fine to coarse, some gravel, medium

252-310 Till, sandy, some sand and gravel, yellow-brown to gray

310-487 Till, sandy, gravelly, few sand and gravel layers at base

CRETACEOUS

DAKOTA FORMATION

487-501 Shale, silty, blue-gray

501-541 Shale, silty, some dolomite, graybrown

541-544 Shale, silty, some pyrite, graybrown

544-550 Sandstone with shale, silty, sandy, light gray

50-550-561 Sandstone, fractured

561-565 Sandstone, fine with shale, silty, gray-brown

565-567 Shale, silty, gray

567-580 Sandstone, fine to medium, $\tan$ to brown 
Table 2. Continued

IGS - D41 (Continued)
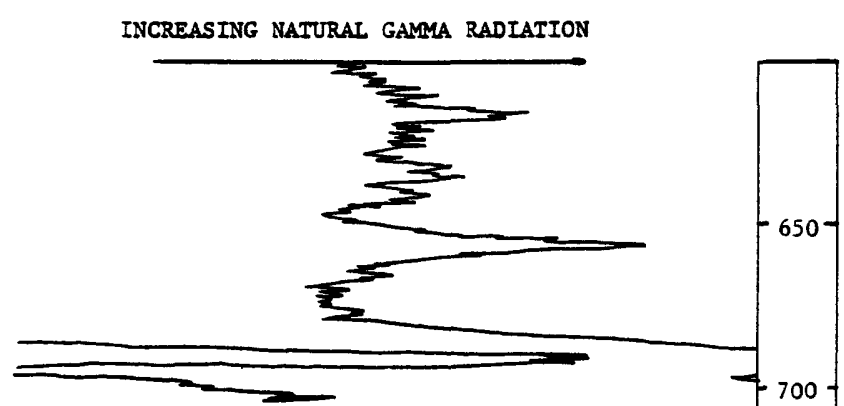

DESCRIPTION OF MATERIALS

580-645 Sandstone, fine to medium, tan and brown

645-688 Sandstone, fine to medium, softer,

less cemented at base, tan

PALEOZOIC UNDIFFERENTIATED

688-695 Shale, sandy, silty, some dark chert, gray-green

695-700 Shale, silty, sandy, light gray

700-701 Shale, maroon and gray-green 
Table 2. Continued

IGS - D38

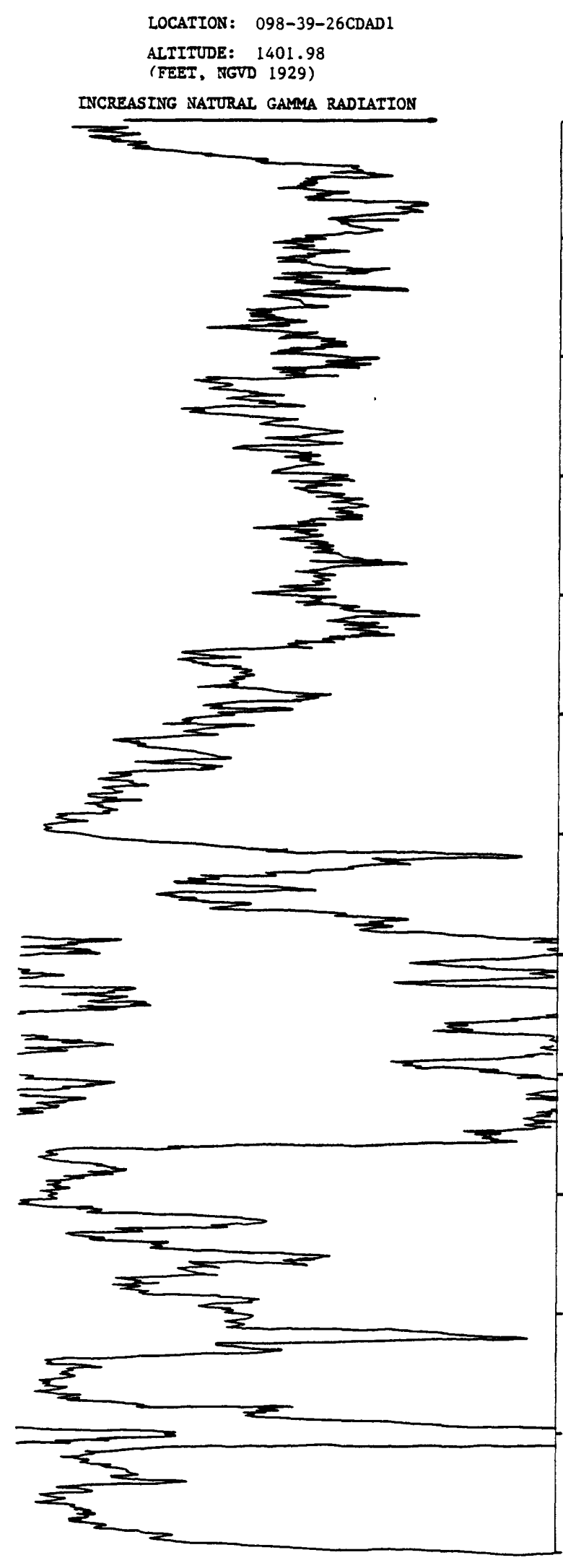

LOCATION: $098-39-26 \mathrm{CDAD} 1$

ALTITDE: 1401.98

(FEET, HGVD 1929)

INCREASING NATURAL GAMMA RADIATIO

250

240-250 Clay, as above, yellow-brown

250-270 Clay, sand and gravel mixed, yellow-brown to brown

270-280 Clay, very sandy

280-300 Clay, sand and gravel mixed, gray-tan

\section{CRETACEOUS}

DAROTA FORMATION

300-320 Shale, interbedded sanstone, gray

320-335 Sandstone, fine, tan

350-335-348 Shale, silty, gray with carbonate at top

348-352 Sandstone, fine, tan

352-385 Shale, silty, interbedded sandstone $370-385$

$400-$

385-425 Shale, very silty, several thin dolomite streaks

425-470 Sandstone, fine to medium, thin shale layers

470-480 Sandstone, fine to medium, grading to coarser

480-490 Sandstone, finer than above, hard

490-502 Sandstone, fine to coarse

500-502-507 Shale, silty, sandy, light gray

507-540 Sandstone, fine to medium, harder than above, tan

540-544 Sandstone, medium to coarse

544-549 Shale, silty, gray

550-549-564 Sandstone, fine to medium, some shale

564-580 Sandstone, fine grading to coarse, tan

580-592 Sandstone, medium to very coarse 
Table 2. Continued

IGS - D38 (Continued)

INCREASING NATURAL GAMMA RADIATION

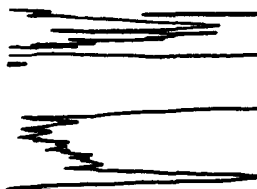

DESCRTPTION OF MATERTALS

PALEOZOIC UNDIFFERENTIATED

592-620 Shale, sandy, silty, light green

to Ifght gray

620-624 Shale, sandy, silty, yellow-brown to gray-green

624-632 Sandstone, medium, light color

- $650-632-640$ Shale, very sandy, some sandstone

640-650 Sandstone, 11ght colored

650-662 Sandstone, shaly, calcareous 


\section{Table 2. Continued}

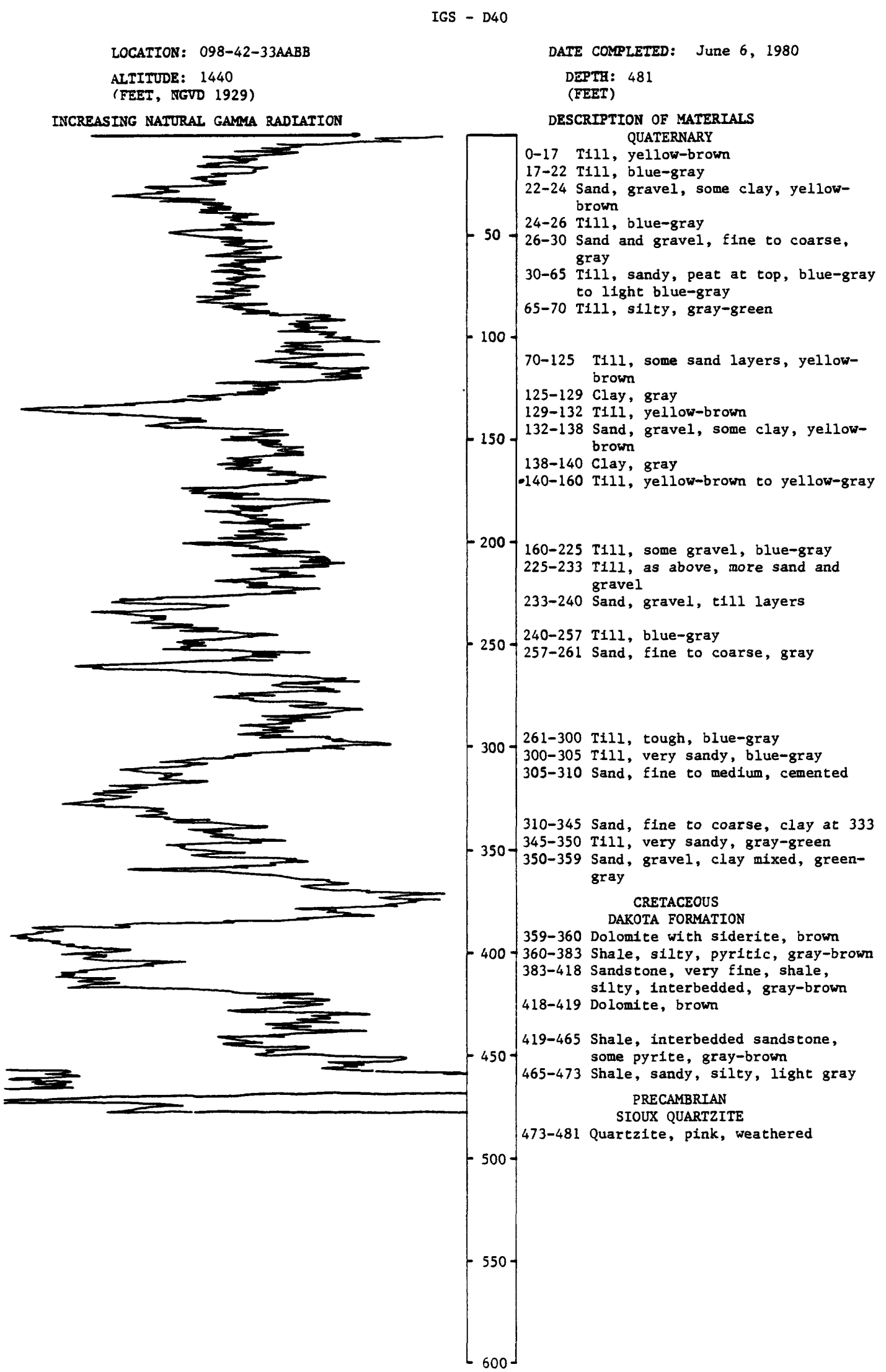


Table 2. Continued

IGS - D20

LOCATION: 098-48-16DDAD

ALTITUDE: 1268

(FEET, NGVD 1929)

INCRRASING NATURAL GAMMA RADIATION

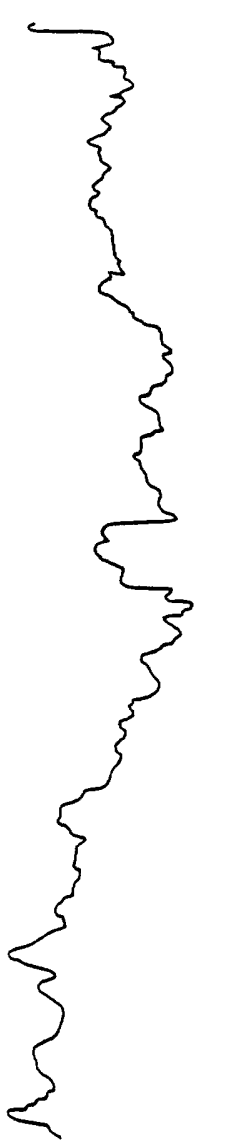

DATE COMPLETED: August 29, 1978 DEPTH: 358 (FEET)

DESCRIPTION OF MATERIALS

QUATERNARY

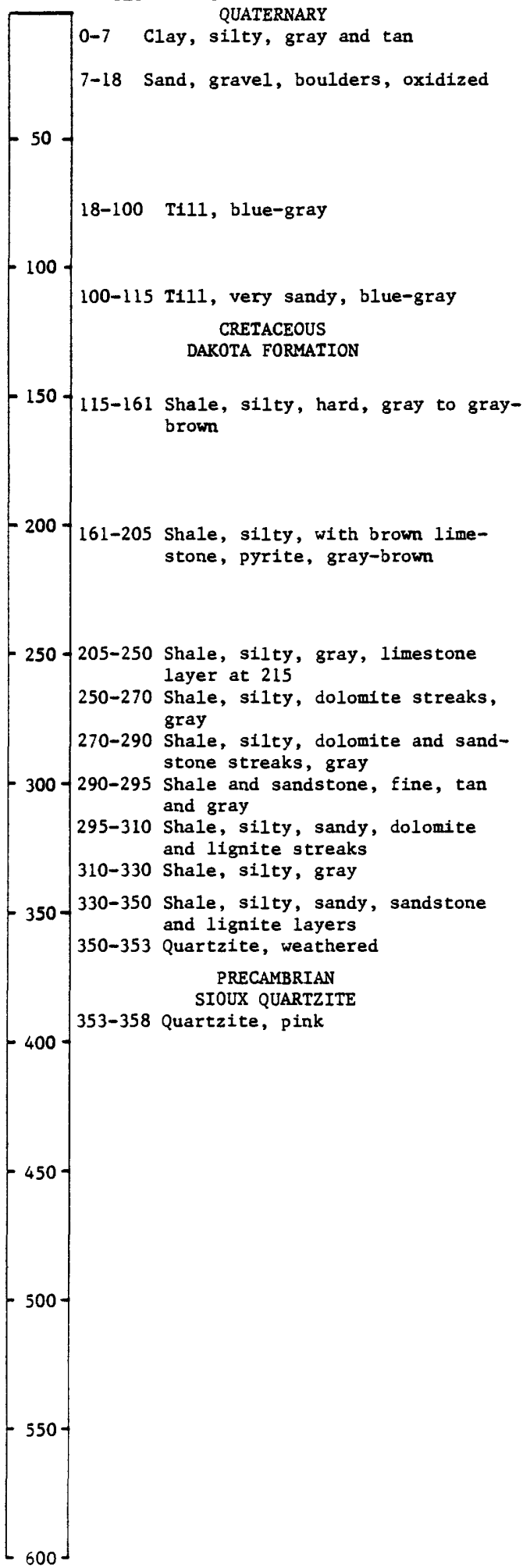


Table 2. Continued

LOCATION: $100-39-17 \mathrm{DCCB}$

ALTITUDE: 1560

(FEEI, NGVD 1929)

INCREASING NAIURAL GAMA RADLATION

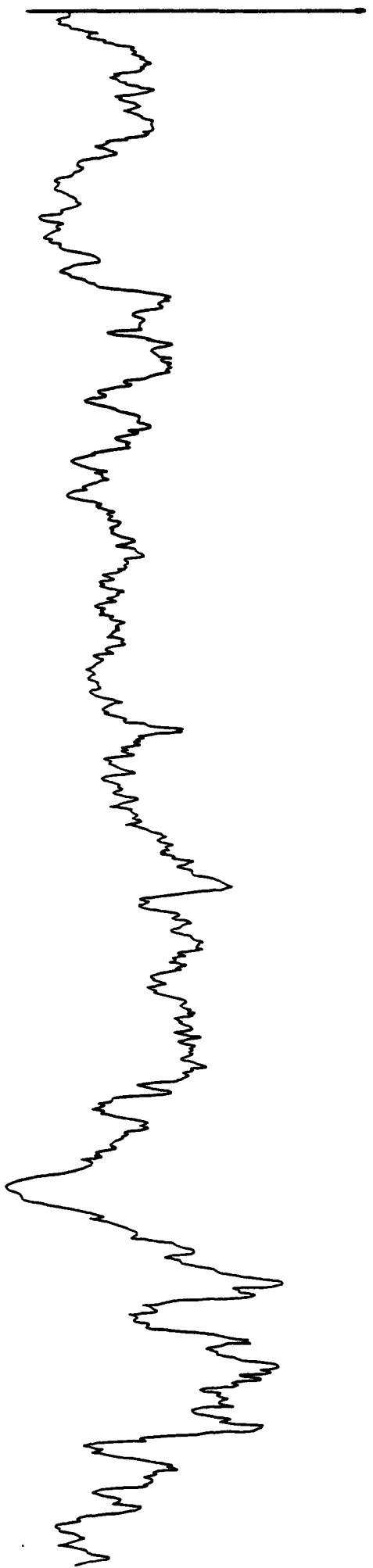

IGS - D13

DATE COMPLETED: June 14,1978

DEPTH: 923

(FEET)

DESCRIPTION OF MATERIALS

QUATERNARY

$0-12$ T111, light yellow

12-14 Sand and gravel, yellow-brown

$50-14-69$ T111, blue-gray

69-109 Sand and gravel, some boulders

$-100$

109-125 Till, sandy, yellow-brown

125-129 Till, very sandy, olive

129-152 Till, blue-gray

- 150 152-157 Clay, silty, gray to light gray

157-166 Till, some gravel, blue-gray

166-168 Sand, fine, gray

168-176 Till, blue-gray

176-190 T111, pebbles, light-gray to

- $200-190-201$ blue-gray

190-201 T111, yellow-gray to gray

201-212 T111, pebbly, light gray

-250-212-278 Till, yellow-gray to blue-gray

278-284 Till, sandy, medium gray

$-300$

284-345 T111, sand and pebbles, very light brown

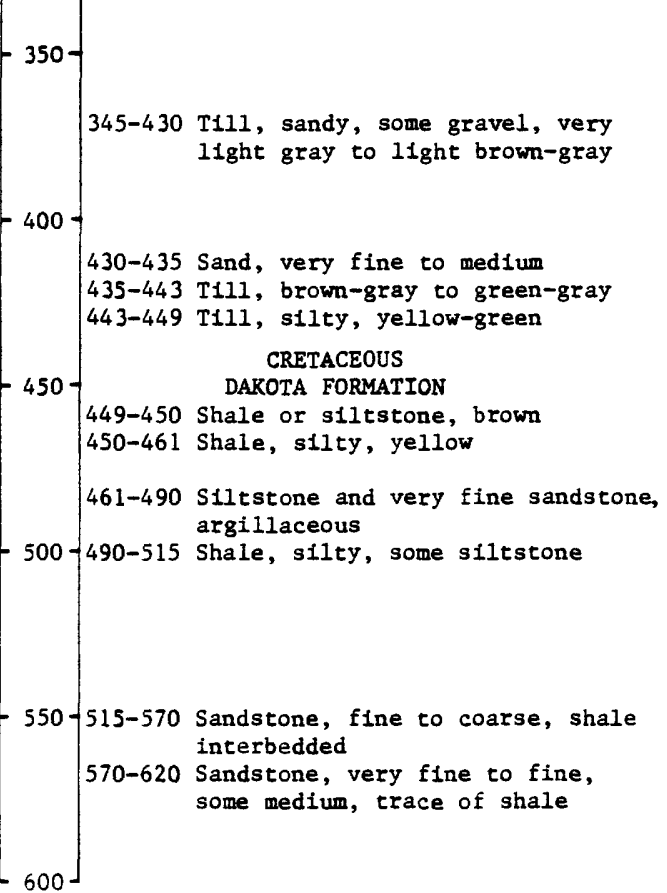


Table 2. Continued

IGS - D13 (Continued)

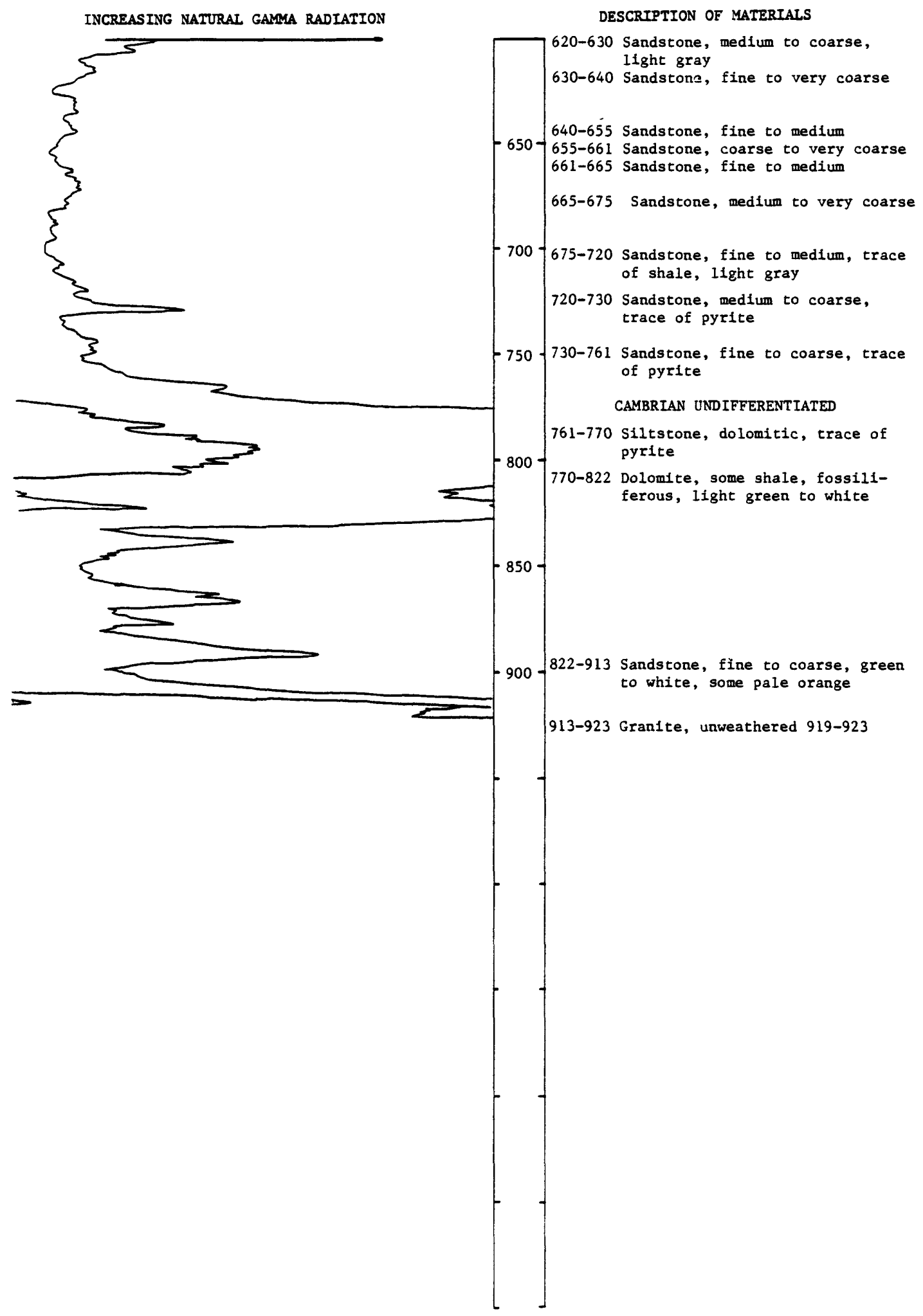


Table 2. Continued

IGS - D45

LOCATION: $100-43-33 \mathrm{CCCD}$

ALTITUDE: 1465

(FEET, NGVD 1929)

INCREASING NATURAL GAMA RADIATION

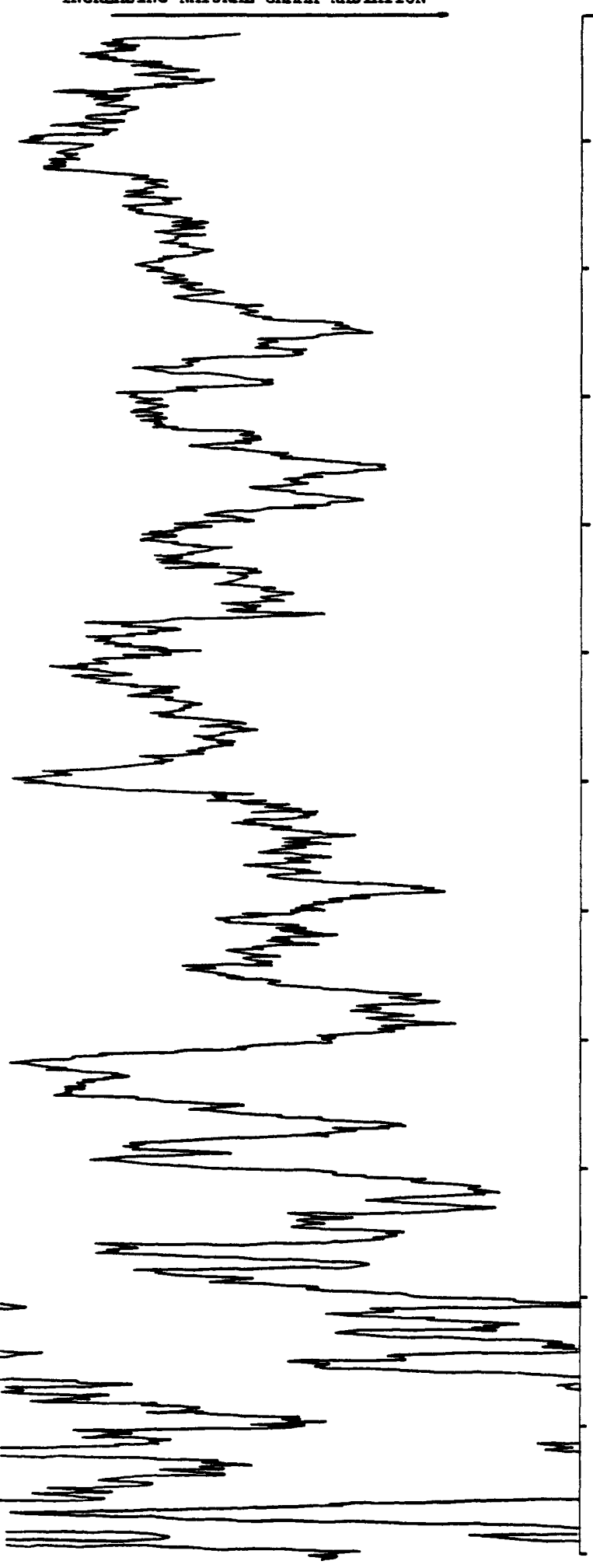

DATE COMPLETED: August 1, 1980

DEPTH: 732

(FEET)

DESCRIPTION OF MATERIALS

QUATERNARY

1-16 T111, yellow-brown

16-17 Sand and gravel, fine to medium, yellow-brown

17-25 T111, yellow-gray

25-32 Sand and gravel, fine to coarse, some tfll and boulders

32-50 Ti11, blue-gray

50-65 Sand and gravel, medium to very coarse, very gray

65-95 Till, sandy, gray to blue-gray

$100\{95-132 \mathrm{Till}$, yellow-gray

132-134 Sand, fine to coarse, brown

134-143 Ti11, gravelly, gray-brown

143-152 Sand and gravel, some t1ll,

150 yellow-brown

152-158 Till, yellow-brown

158-162 Sand and gravel, fine to coarse, yellow-brown

200

175-260 Till, sandy, some gravel, bluegray

250

260-290 Till, blue-gray

290-298 Sand and gravel, fine to coarse, some till, gray

$300-298-310 \mathrm{~T} i 11$, gray to blue-gray

310-317 Clay, sandy, gray-brown

317-340 Clay, hard, dark gray

340-379 Till, sandy, light blue-gray

CRETACEOUS

DAKOTA FORMATION

$400-379-430$ Shale, some silty, pyrite, some dolomite beds less than 1 foot thick

430-441 Shale, silty, sandy, lignite, some sandstone

441-445 Sandstone, fine, interbedded shale and dolomite

445-455 Shale, silty, gray-brown

455-460 Dolomite, pyrite, tan to brown

460-463 Shale, silty, gray and lignite

463-470 Sandstone, fine to very fine, interbedded shale

$500-470-473$ Shale, silty, sandy, dolomite, brown

473-480 Sandstone, very fine, interbedded shale, silty, gray

$550-$

480-570 Shale, silty, gray to brown, interbedded dolomite, lignite and black shale

570-600 Shale, silty, gray, interbedded sandstone 
Table 2. Continued

IGS - D45 (Continued)

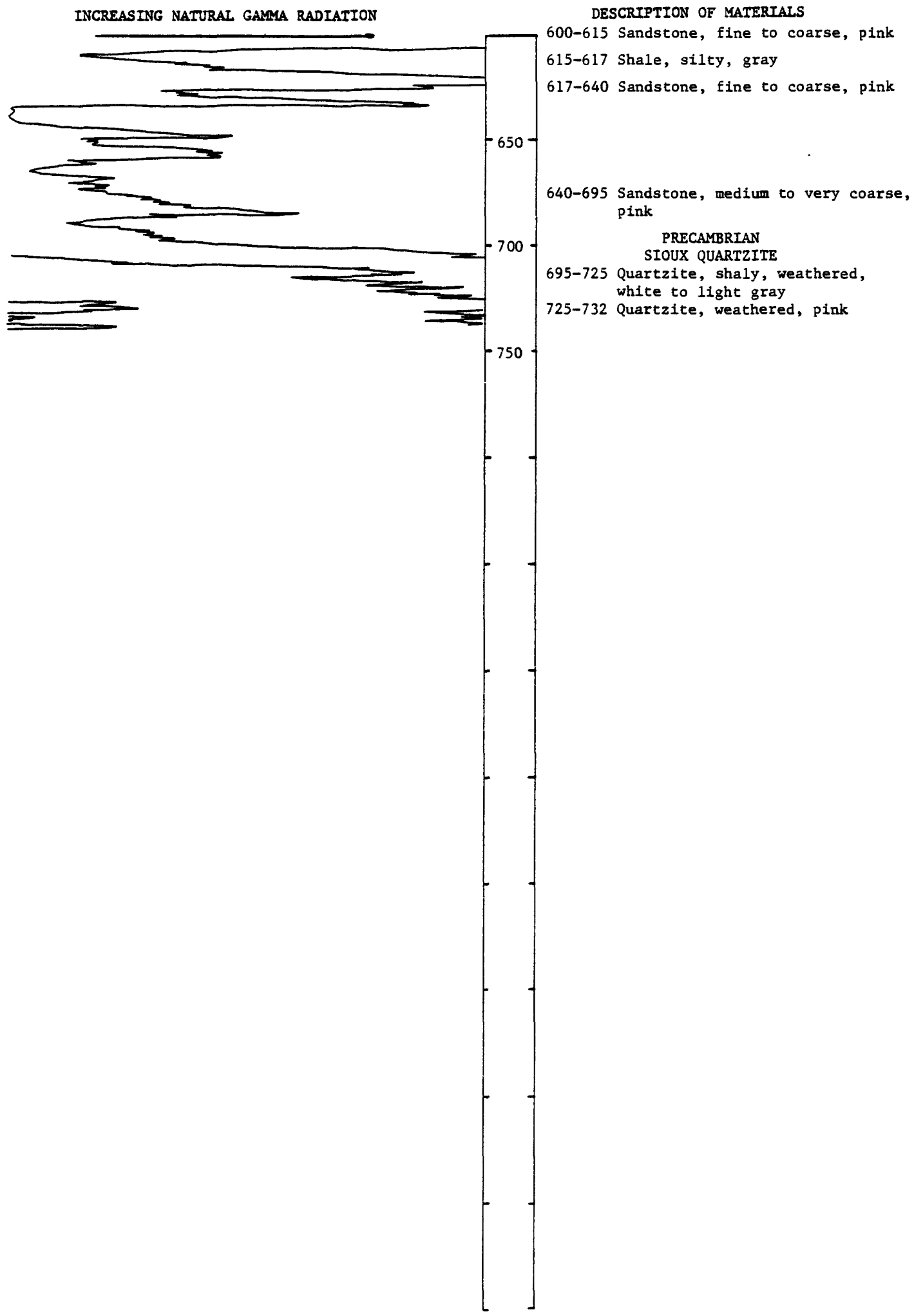


Table 2. Continued

IGS - D19

LOCATION: $100-48-31 \mathrm{CCCC}$

ALTITUDE: 1417

(FEET, NGVD 1929)

INCREASING NATURAL GAMMA RADIATION

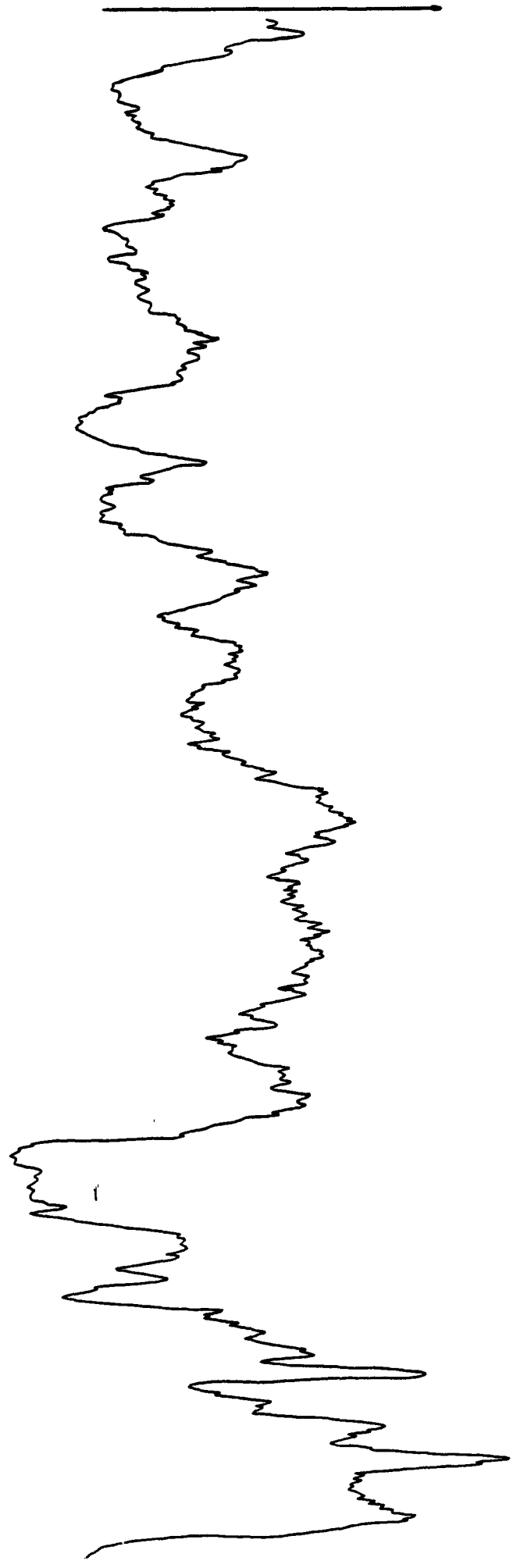

DATE COMPLETED: August 21, 1980

DEPTH: 657

(FEET)

DESCRIPTION OF MATERIALS

-


Table 2. Continued

IGS - D19 (Continued)

INCREASING NATURAL GAMMA RADIATION

DESCRIPTION OF MATERIALS

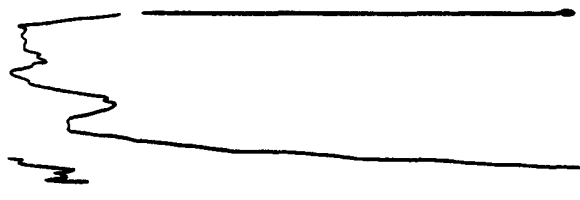

610-644 Sandstone, fine to coarse

650-644-653 Shale, silty, sandy, white

PRECAMBRIAN

SIOUX QUARTZITE

653-657 Quartzite, weathered, pink

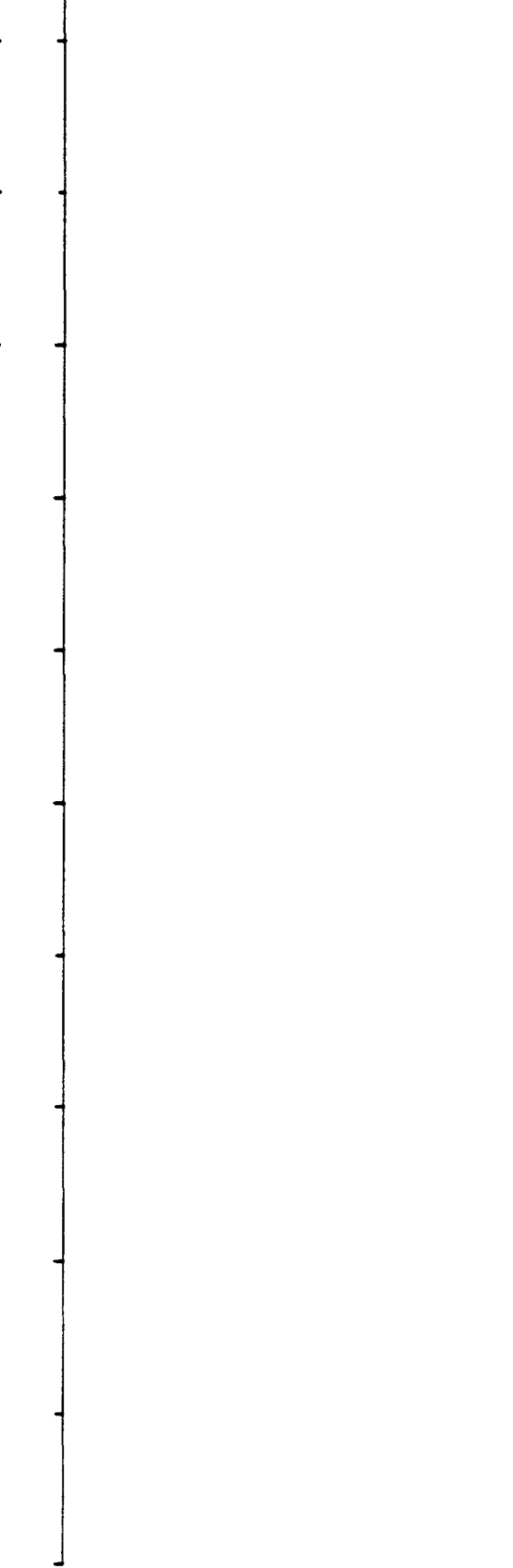


Table 3. Water levels in observation wells

[Water levels are shown as altitude in feet above the National Geodetic Vertical Datum (NGVD), 1929. The altitude of land surface is shown in parentheses after the location of each well. MP, measuring point; Isd, land surface datum]

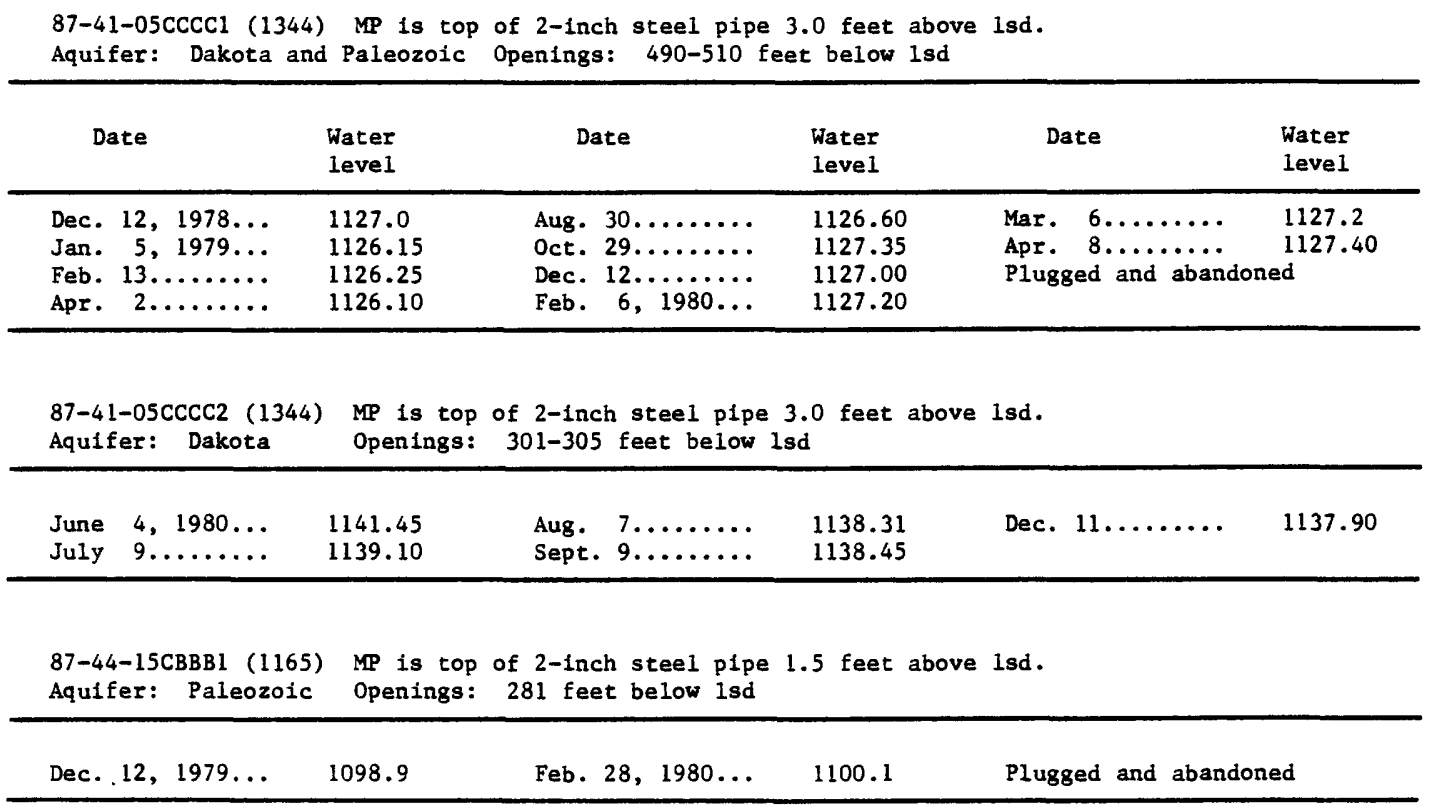

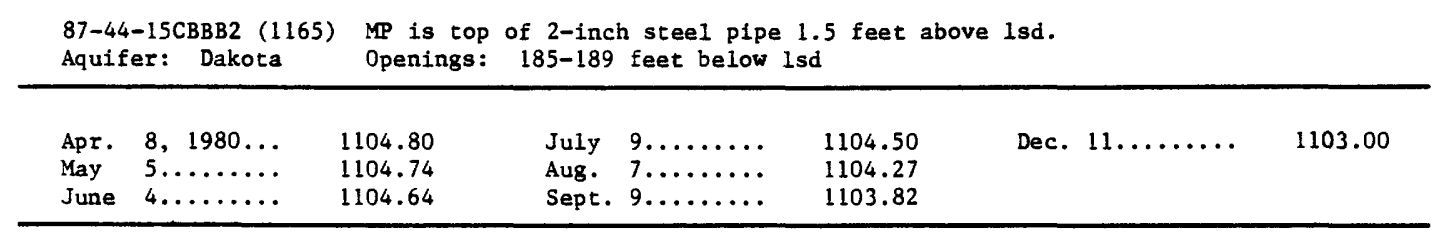

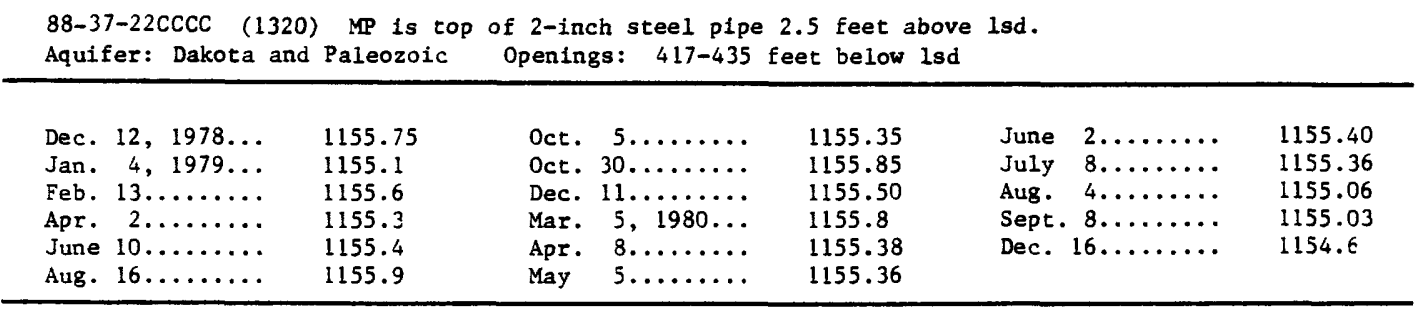

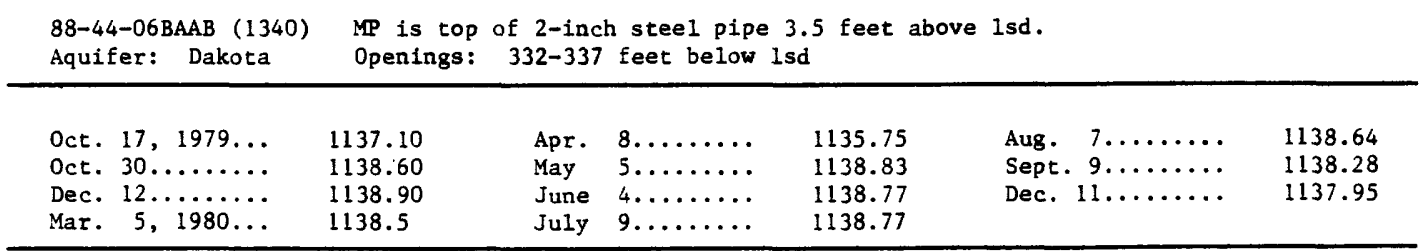


Table 3. Continued

89-38-36CBCC (1445) MP is top of 2-inch steel pipe 4.0 feet above 1sd. Aquifer: Dakota Openings: 410-430 feet below lsd

\begin{tabular}{|c|c|c|c|c|c|}
\hline Date & $\begin{array}{l}\text { Water } \\
\text { level }\end{array}$ & Date & $\begin{array}{l}\text { Water } \\
\text { level }\end{array}$ & Date & $\begin{array}{l}\text { Water } \\
\text { level }\end{array}$ \\
\hline $\begin{array}{l}\text { Dec. } 12,1978 \ldots \\
\text { Jan. } 4,1979 \ldots \\
\text { Feb. } 13 \ldots \ldots \\
\text { Apr. } 2 \ldots \ldots \\
\text { June } 10 \ldots \ldots \\
\text { Aug. } 16 \ldots \ldots \\
\text { Aug. } 30 \ldots \ldots \\
\text { A. } 3 \ldots \ldots\end{array}$ & $\begin{array}{l}1154.7 \\
1154.0 \\
1154.0 \\
1154.1 \\
1154.2 \\
1154.1 \\
1154.2\end{array}$ & 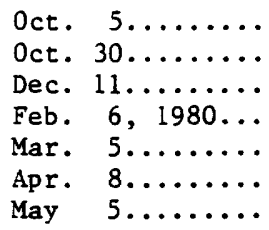 & $\begin{array}{l}1156.6 \\
1155.0 \\
1154.15 \\
1153.92 \\
1155.10 \\
1153.50 \\
1154.68\end{array}$ & $\begin{array}{l}\text { June } \quad 2 \ldots \ldots \ldots \\
\text { July } \quad 8 \ldots \ldots \ldots \\
\text { Aug. } \quad 4 \ldots \ldots \ldots \\
\text { Sept. } 5 \ldots \ldots \ldots \\
\text { Dec. } 16 \ldots \ldots \ldots\end{array}$ & $\begin{array}{l}1156.95 \\
1154.28 \\
1154.40 \\
1153.92 \\
1153.90\end{array}$ \\
\hline
\end{tabular}

89-41-13CCCC (1320) MP is top of 2-inch steel pipe 1.5 feet above 1 sd.

Aquifer: Paleozoic Openings: 465-468 feet below lsd

\begin{tabular}{|c|c|c|c|c|c|}
\hline $\begin{array}{l}\text { Dec. } 12,1978 \ldots \\
\text { Jan. } 5,1979 \ldots \\
\text { Feb. } 13 \ldots \ldots \ldots \ldots \\
\text { Apr. } 2 \ldots \ldots \ldots \\
\text { Aug. } 30 \ldots \ldots \ldots \\
\text { Oct. } 29 \ldots \ldots \ldots \ldots\end{array}$ & $\begin{array}{l}1129.2 \\
1129.00 \\
1128.85 \\
1128.90 \\
1130.15 \\
1130.45\end{array}$ & $\begin{array}{lr}\text { Dec. } & 12 \ldots \ldots \ldots \ldots \\
\text { Feb. } & 5,1980 \ldots \\
\text { Mar. } & 6 \ldots \ldots \ldots \ldots \\
\text { Mar. } 12 \ldots \ldots \ldots \\
\text { Apr. } \quad 8 \ldots \ldots \ldots \ldots \\
\text { Apr. } 8 \ldots \ldots \ldots \ldots\end{array}$ & $\begin{array}{l}1130.40 \\
1131.70 \\
1122.00 \\
\text { pumped } \\
1112.86 \\
\text { pumped }\end{array}$ & $\begin{array}{ll}\text { May } & 5 \ldots \ldots \ldots \\
\text { July } & 9 \ldots \ldots \ldots \\
\text { Aug. } & 6 \ldots \ldots \ldots \\
\text { Sept. } & 9 \ldots \ldots \ldots \\
\text { Dec. } & 11 \ldots \ldots \ldots\end{array}$ & $\begin{array}{r}959.99 \\
1075.45 \\
1093.00 \\
1105.90 \\
1127.90\end{array}$ \\
\hline
\end{tabular}

89-44-20DCDC (1160) MP is top of 2-inch steel pipe 4.0 feet above 1sd. Aquifer: Dakota Openings: 206-221 feet below lsd

\begin{tabular}{llllll}
\hline 0ct. $16,1979 \ldots$ & 1134.0 & Apr. $8 \ldots \ldots \ldots$ & 1134.50 & Aug. $6 \ldots \ldots$ & $6 \ldots$ \\
Oct. $30 \ldots \ldots \ldots$ & 1134.15 & May & $5 \ldots \ldots \ldots$ & 1134.28 & Sept. $9 \ldots \ldots$ \\
Dec. $12 \ldots \ldots \ldots \ldots$ & 1134.7 & June & $4 \ldots \ldots \ldots$ & 1134.52 & Dec. $11 \ldots \ldots$ \\
Mar. $6,1980 \ldots$ & 1136.1 & July & $9 \ldots \ldots \ldots$ & 1134.14 & \\
\hline
\end{tabular}

89-46-36BBDC1 (1268) MP is top of 2-inch steel pipe 3.0 feet above Isd. Aquifer: Paleozoic Openings: 519-537 feet below lsd

\begin{tabular}{|c|c|c|c|c|c|}
\hline $\begin{array}{l}\text { Oct. } 10,1979 \ldots \\
\text { Oct. } 30, \ldots \ldots \ldots\end{array}$ & $\begin{array}{l}1107.25 \\
1129.25\end{array}$ & $\begin{array}{l}\text { Dec. } 12 \ldots \ldots \ldots \\
\text { Feb. } 1,1980 \ldots\end{array}$ & $\begin{array}{l}1129.7 \\
1129.4\end{array}$ & $\begin{array}{l}\text { Feb. } 28 \ldots \ldots \ldots \\
\text { Plugged and abandone }\end{array}$ & $\begin{array}{l}1129.8 \\
\text { ed }\end{array}$ \\
\hline $\begin{array}{l}\text { 89-46-36BBDC2 (1268) } \\
\text { Aquifer: Dakota }\end{array}$ & $\begin{array}{l}\text { MP is top } \\
\text { Openings: }\end{array}$ & $\begin{array}{l}\text { of 2-inch steel pipe } \\
358-362 \text { feet below }\end{array}$ & $\begin{array}{l}3.0 \text { feet above } \\
\text { sd }\end{array}$ & 1sd. & \\
\hline $\begin{array}{ll}\text { Apr. } & 8,1980 \ldots \\
\text { May } & 5 \ldots \ldots \ldots \\
\text { June } & 4 \ldots \ldots \ldots\end{array}$ & $\begin{array}{l}1134.88 \\
1137.20 \\
1134.55\end{array}$ & $\begin{array}{l}\text { July } \quad 9 \ldots \ldots \ldots \\
\text { Aug. } \quad 7 \ldots \ldots \ldots \\
\text { Sept. } 9 \ldots \ldots \ldots\end{array}$ & $\begin{array}{l}1134.45 \\
1133.64 \\
1133.69\end{array}$ & Dec. $11 \ldots \ldots \ldots$ & 1133.50 \\
\hline
\end{tabular}

90-36-13ADDA (1281) MP is top of 2-inch steel pipe 3.3 feet above 1sd.

Aquifer: Paleozoic Openings: 223-235 feet below Isd

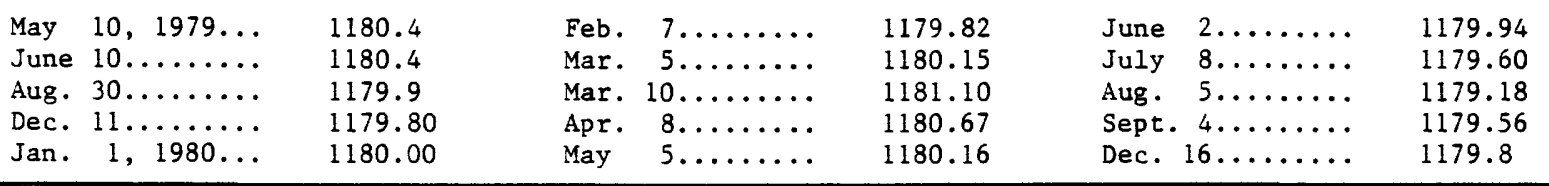


Table 3. Continued

90-38-16DDDD1 (1365) MP is top of 2-inch steel pipe 3.5 feet above 1sd. Aquifer: Paleozoic Openings: 499-517 feet below lsd

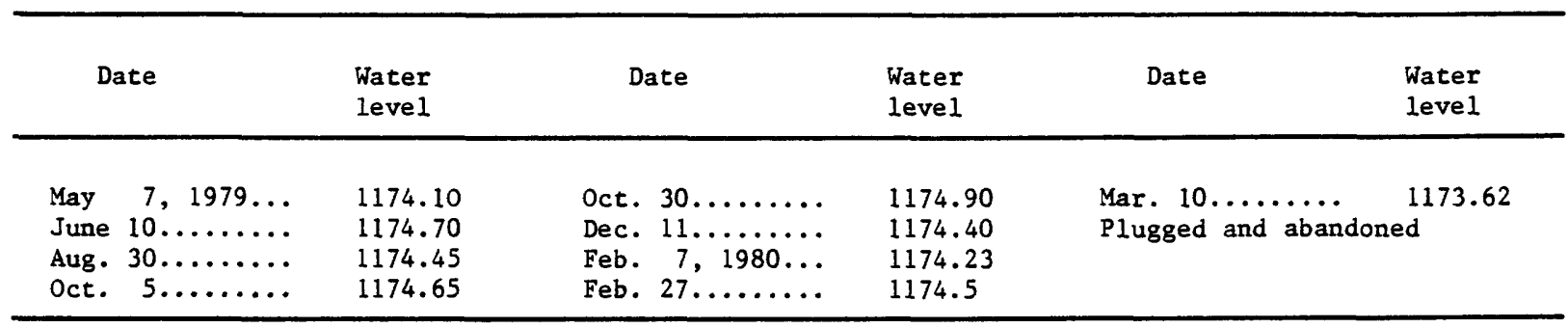

90-38-16DDDD2 (1365) MP is top of 2-inch steel pipe 3.5 feet above 1 sd. Aquifer: Dakota Openings: $346.5-349.5$ feet below $1 \mathrm{sd}$

\begin{tabular}{lllllll}
\hline & & & & & & \\
Apr. & $8,1980 \ldots$ & 1176.70 & July & $8 \ldots \ldots \ldots \ldots$ & 1176.69 & Dec. $16 \ldots \ldots$ \\
May & $5 \ldots \ldots \ldots$ & 1176.73 & Aug. $4 \ldots \ldots \ldots \ldots$ & 1176.62 & 1176.15 \\
June & $2 \ldots \ldots \ldots \ldots$ & 1176.75 & Sept. $4 \ldots \ldots \ldots \ldots$ & 1176.54 & \\
\hline
\end{tabular}

90-40-06BDCD (1182) MP is top of 1.25-inch steel pipe 4.0 feet above 1 sd. Aquifer: Dakota Openings: 252-254 feet below lsd

\begin{tabular}{|c|c|c|c|c|c|}
\hline $\begin{array}{l}\text { Dec. } 12,1978 \ldots \\
\text { Jan. } 5,1979 \ldots \\
\text { Feb. } 13 \ldots \ldots \\
\text { Apr. } 2 \ldots \ldots \ldots \\
\text { Aug. } 30 \ldots \ldots \ldots \\
\text { Sept. } 29 \ldots \ldots \ldots\end{array}$ & $\begin{array}{l}1145.4 \\
1145.2 \\
1145.25 \\
1148.3 \\
1148.15 \\
1148.10\end{array}$ & $\begin{array}{lr}\text { Dec. } & 12 \ldots \ldots \ldots \\
\text { Feb. } & 5,1980 \ldots \\
\text { Mar. } & 6 \ldots \ldots \ldots \\
\text { Mar. } & 31 \ldots \ldots \\
\text { May } & 5 \ldots \ldots \ldots \\
\text { June } & 4 \ldots \ldots \ldots \\
\text {. . . . . . }\end{array}$ & $\begin{array}{l}1149.30 \\
1148.25 \\
1148.15 \\
1148.4 \\
1148.74 \\
1148.20\end{array}$ & $\begin{array}{l}\text { July } \quad 9 \ldots \ldots \ldots \ldots \\
\text { Aug. } \quad 6 \ldots \ldots \ldots \\
\text { Sept } \quad 4 \ldots \ldots \ldots \\
\text { Dec. } 11 \ldots \ldots\end{array}$ & $\begin{array}{l}1148.01 \\
1147.45 \\
1147.06 \\
1146.0\end{array}$ \\
\hline
\end{tabular}

91-35-26BCCC (1291) MP is top of 2-inch steel pipe 2.0 feet above 1 sd. Aquifer: Dakota Openings: $338-347$ feet below lsd

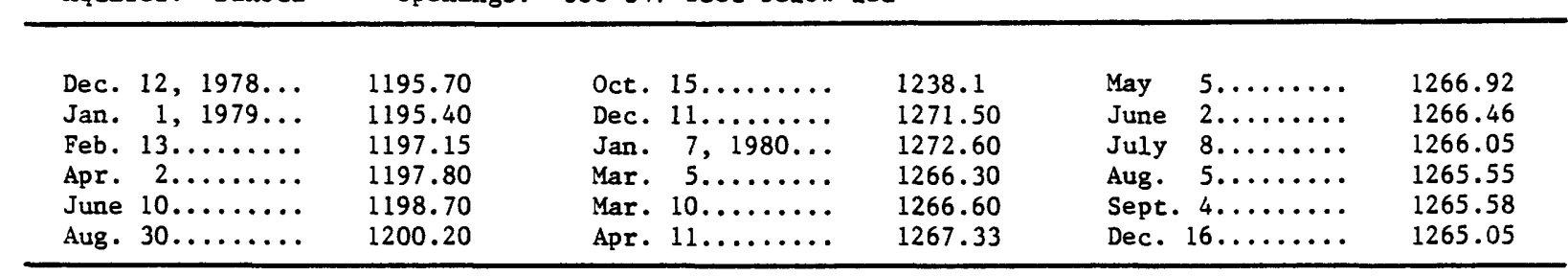

91-39-01ADAD1 (1370) MP is top of 6-inch steel pipe 3.2 feet above 1 sd. Aquifer: Paleozoic Openings: $1126-1545$ feet below lsd

\begin{tabular}{|c|c|c|c|c|c|c|}
\hline $\begin{array}{l}\text { Sept. } 13,1979 \ldots \\
\text { Dec. } 11 \ldots \ldots \\
\text { Feb. } 7,1980 \ldots \\
\text { Apr. } 8 \ldots \ldots\end{array}$ & $\begin{array}{l}1176.2 \\
1176.05 \\
1175.90 \\
1176.70\end{array}$ & $\begin{array}{l}\text { May } \\
\text { June } \\
\text { July } \\
\text { Aug. }\end{array}$ & $\begin{array}{c}5 \ldots \ldots \ldots \\
4 \ldots \ldots \\
10 \ldots \ldots \\
6 \ldots \ldots \ldots\end{array}$ & $\begin{array}{l}1176 \cdot 36 \\
1176 \cdot 37 \\
1176 \cdot 24 \\
1176.21\end{array}$ & $\begin{array}{l}\text { Sept } 4 \ldots \ldots \ldots \\
\text { Dec } 16 \ldots \ldots\end{array}$ & $\begin{array}{l}1175.81 \\
1174.75\end{array}$ \\
\hline
\end{tabular}

91-39-01ADAD2 (1370) MP is top of 4-inch steel pipe 3.3 feet above 1 sd. Aquifer: Dakota Openings: 235-240 feet below lsd

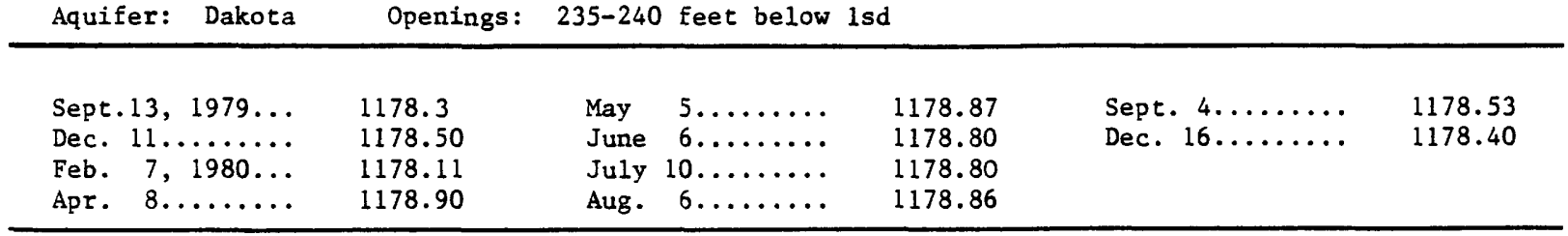


Table 3. Continued

91-42-16DDDD1 (1320) MP is top of 2-inch steel pipe 1.5 feet above 1 sci.

Aquifer: Paleozoic Openings: 561-576 feet below lsd

\begin{tabular}{|c|c|c|c|c|c|}
\hline Date & $\begin{array}{l}\text { Water } \\
\text { leve1 }\end{array}$ & Date & $\begin{array}{l}\text { Water } \\
\text { level }\end{array}$ & Date & $\begin{array}{l}\text { Water } \\
\text { level }\end{array}$ \\
\hline $\begin{array}{l}\text { Dec. } 12,1978 \ldots \\
\text { Apr. } 2,1979 \ldots \\
\text { May } \quad 7 \ldots \ldots \ldots . \\
\text { June } 10 . \ldots \ldots \ldots .\end{array}$ & $\begin{array}{l}1180.90 \\
1179.20 \\
1180.15 \\
1163.80\end{array}$ & $\begin{array}{l}\text { Aug. } 29 \ldots \ldots \ldots \\
\text { Sept. } 13 \ldots \ldots \ldots \ldots \\
\text { Oct. } \quad 4 \ldots \ldots \ldots \ldots \\
\text { Oct. } 29 \ldots \ldots \ldots\end{array}$ & $\begin{array}{l}1164.50 \\
1164.20 \\
1164.20 \\
1165.40\end{array}$ & $\begin{array}{l}\text { Dec. } 12 \ldots \ldots \ldots \\
\text { Feb. } 5,1980 \ldots \\
\text { Feb. } 27 \ldots \ldots \ldots \\
\text { Plugged and aband }\end{array}$ & $\begin{array}{l}1164.8 \\
1165.90 \\
1164.9\end{array}$ \\
\hline
\end{tabular}

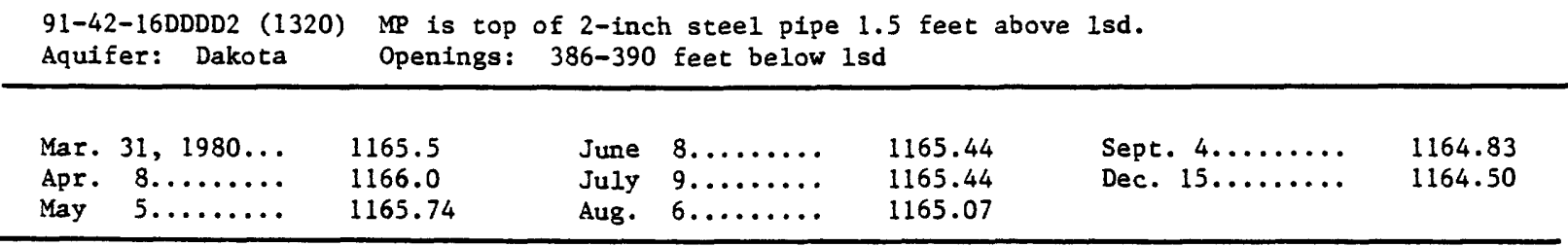

\begin{tabular}{|c|c|c|c|c|c|c|c|c|}
\hline $\begin{array}{l}92-40 \\
\text { Aqui }\end{array}$ & $\begin{array}{l}\text {-10BDDD ( } 121 \\
\text { er: Dakota }\end{array}$ & $\begin{array}{l}\text { MP is top } \\
\text { Openings: }\end{array}$ & $\begin{array}{l}\text { f } 2.5-1 \\
114-118\end{array}$ & $\begin{array}{l}\text { ach steel p } \\
\text { feet below }\end{array}$ & at 1sd. & & & \\
\hline $\begin{array}{l}\text { Apr. } \\
\text { May }\end{array}$ & $\begin{array}{l}7,1980 \ldots \\
7 \ldots \ldots\end{array}$ & $\begin{array}{l}1182.0 \\
1181.66\end{array}$ & $\begin{array}{l}\text { June } \\
\text { July }\end{array}$ & $\begin{array}{l}4 \ldots \ldots \ldots \\
8 \ldots \ldots \ldots\end{array}$ & $\begin{array}{l}1181.52 \\
1181.28\end{array}$ & $\begin{array}{l}\text { Aug. } \\
\text { Sept. }\end{array}$ & $\begin{array}{l}6 \ldots \ldots \ldots \\
4 \ldots \ldots\end{array}$ & $\begin{array}{l}1180.90 \\
1180.94\end{array}$ \\
\hline
\end{tabular}

92-45-02CBCBI (1245) MP is top of 5-inch steel pipe 3.2 feet above 1 sd. Aquifer: Paleozoic Openings: 598-1089 feet below lsd

\begin{tabular}{|c|c|c|c|c|c|}
\hline $\begin{array}{l}\text { May } \quad 7,1979 \ldots \\
\text { Aug. } \quad 31 \ldots \ldots \ldots \ldots \\
\text { Oct. } \quad 4 \ldots \ldots \ldots \ldots \\
\text { Dec. } 12 \ldots \ldots \ldots \\
\text { Feb. } 22,1980 \ldots\end{array}$ & $\begin{array}{l}1149.10 \\
1148.90 \\
1148.20 \\
1149.30 \\
1149.70\end{array}$ & $\begin{array}{lr}\text { Mar. } & 12 \ldots \ldots \ldots \\
\text { Apr. } & 8 \ldots \ldots \ldots \ldots \\
\text { May } & 5 \ldots \ldots \ldots \ldots \\
\text { June } & 8 \ldots \ldots \ldots \ldots \\
\text { July } & 9 \ldots \ldots \ldots \ldots\end{array}$ & $\begin{array}{l}1149.75 \\
1147.43 \\
1145.87 \\
1145.86 \\
1144.29\end{array}$ & $\begin{array}{l}\text { Aug. } \quad 6 \ldots \ldots \ldots \ldots \\
\text { Sept. } 4 \ldots \ldots \ldots \ldots \\
\text { Dec. } 15 \ldots \ldots \ldots \ldots\end{array}$ & $\begin{array}{l}1142.90 \\
1143.71 \\
1145.65\end{array}$ \\
\hline
\end{tabular}

92-45-02CBCB2 (1245) MP is top of 4-inch steel pipe 3.5 feet above 1sd. Aquifer: Dakota Openings: $347-365$ feet below lsd

\begin{tabular}{|c|c|c|c|c|c|c|}
\hline $\begin{array}{l}\text { Apr. } 17,1979 \ldots \\
\text { May } \quad 7 \ldots \ldots \ldots \ldots \\
\text { Aug. } 16 \ldots \ldots \ldots \ldots \\
\text { Dec. } 12 \ldots \ldots \ldots \ldots \\
\text { Jan. } 21,1980 \ldots\end{array}$ & $\begin{array}{l}1143.8 \\
1143.8 \\
1143.8 \\
1144.7 \\
1145.1\end{array}$ & $\begin{array}{l}\text { Feb. } \\
\text { Apr. } \\
\text { May } \\
\text { June } \\
\text { July }\end{array}$ & $\begin{array}{c}22 \ldots \ldots \ldots \\
8 \ldots \ldots \ldots \\
6 \ldots \ldots \ldots \\
8 \ldots \ldots \ldots \\
9 \ldots \ldots \ldots\end{array}$ & $\begin{array}{l}1145.15 \\
1144.40 \\
1142.70 \\
1142.99 \\
1141.16\end{array}$ & $\begin{array}{l}\text { Aug. } \quad 6 \ldots \ldots \ldots \\
\text { Sept } \quad 4 \ldots \ldots \ldots \\
\text { Dec. } 15 \ldots \ldots \ldots\end{array}$ & $\begin{array}{l}1139.66 \\
1138.44 \\
1142.9\end{array}$ \\
\hline
\end{tabular}

92-45-02CBAB (1220) MP is top of 4-inch steel pipe 5.0 feet above 1sd.

Aquifer: Quaternary Openings: 10-22 feet below lsd

\begin{tabular}{|c|c|c|c|c|c|c|}
\hline $\begin{array}{l}\text { Apr. } 17,1979 \ldots \\
\text { May } \quad 7 \ldots \ldots \ldots \\
\text { Aug. } 16 \ldots \ldots \ldots \\
\text { Oct. } 4 \ldots \ldots \ldots \ldots \\
\text { Dec. } 12 \ldots \ldots \ldots \ldots\end{array}$ & $\begin{array}{l}1213.85 \\
1213.20 \\
1213.25 \\
1212.7 \\
1216.5\end{array}$ & $\begin{array}{l}\text { Mar. } \\
\text { Apr. } \\
\text { May } \\
\text { June } \\
\text { July }\end{array}$ & $\begin{array}{l}4,1980 \ldots \\
8 \ldots \ldots \ldots \\
6 \ldots \ldots \ldots \\
5 \ldots \ldots \ldots \\
9 \ldots \ldots \ldots\end{array}$ & $\begin{array}{l}1213.50 \\
1214.95 \\
1213.12 \\
1214.65 \\
1212.67\end{array}$ & $\begin{array}{l}\text { Aug. } \quad 6 \ldots \ldots \ldots \\
\text { Sept. } 3 \ldots \ldots \ldots \ldots \\
\text { Dec. } 15 \ldots \ldots \ldots\end{array}$ & $\begin{array}{l}1212.19 \\
1213.77 \\
1212.30\end{array}$ \\
\hline
\end{tabular}


Table 3. Continued

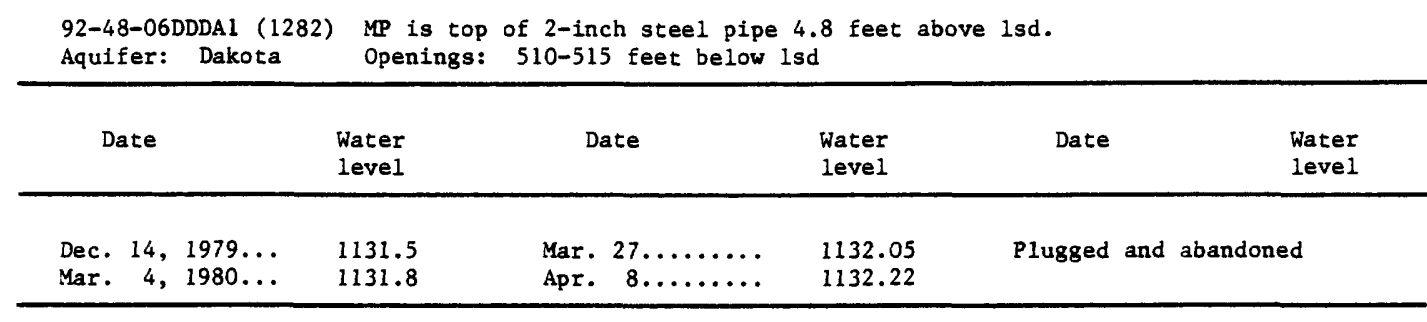

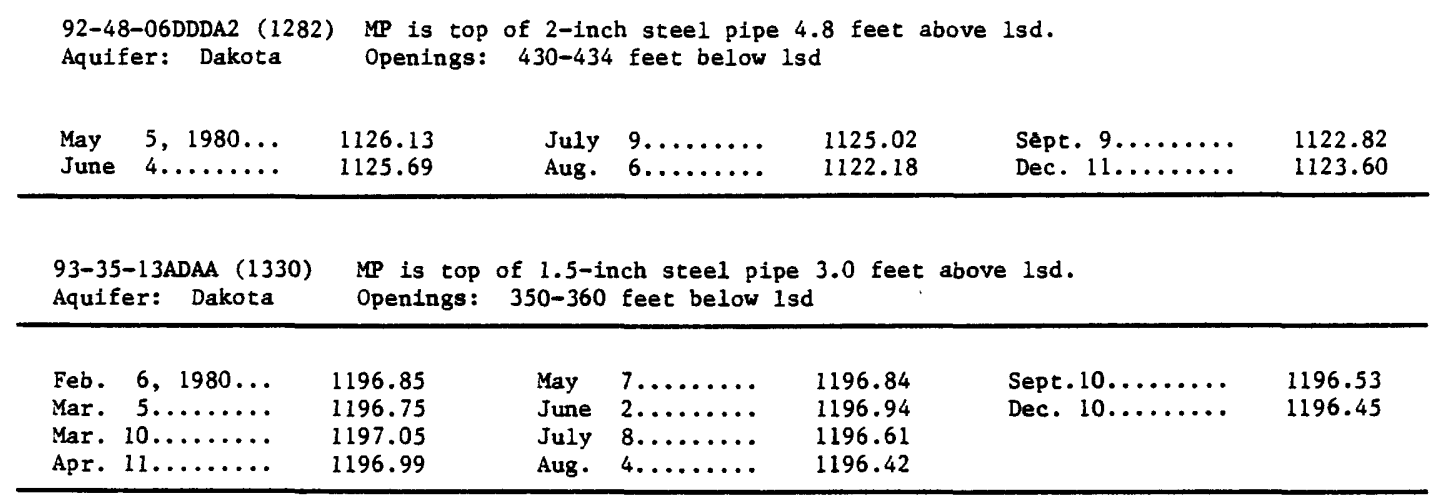

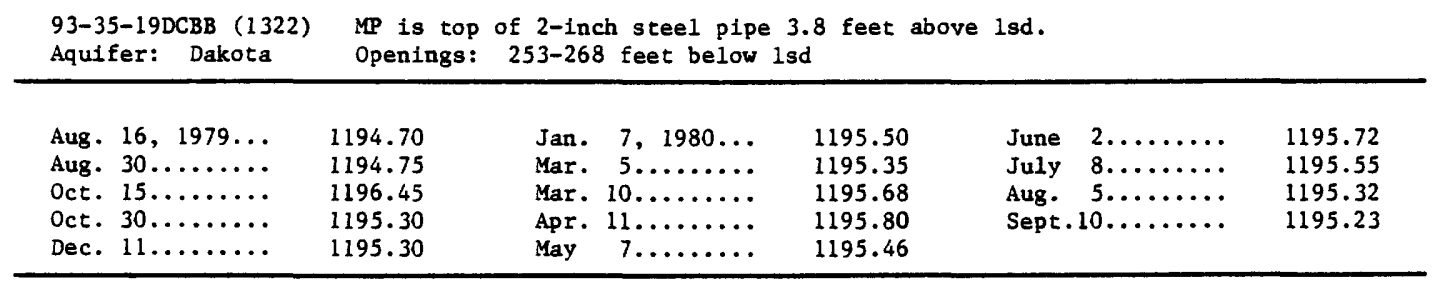

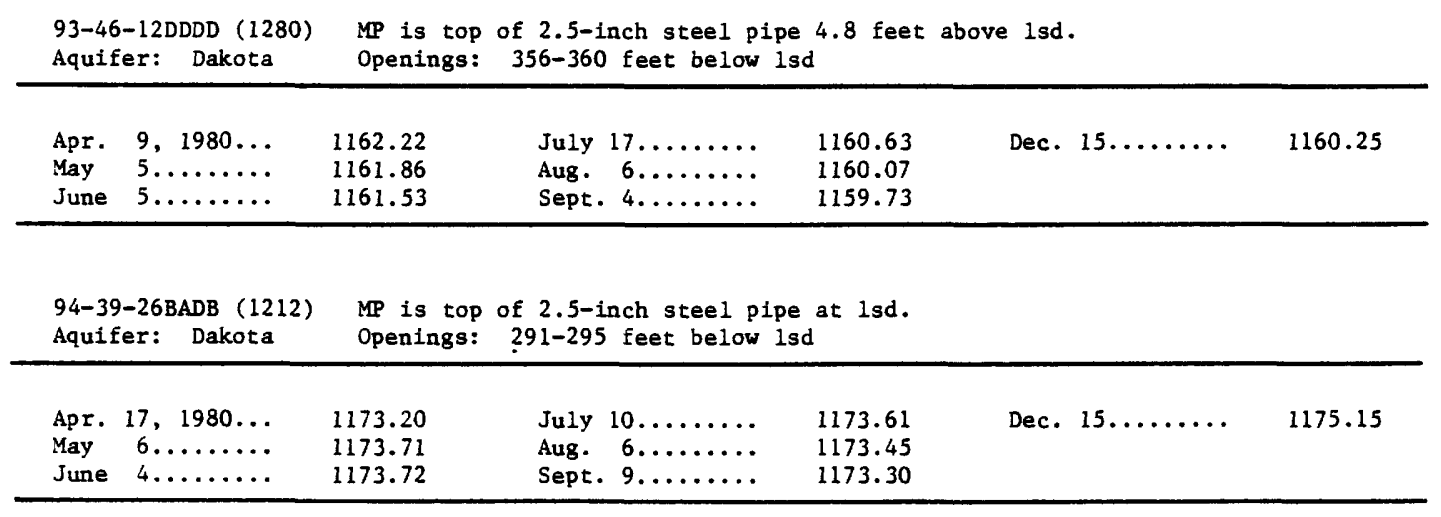

94-42-09DDDD (1440) MP is top of 2-inch steel pipe 4.0 feet above 1 sd. Aquifer: Dakota Openings: 516-536 feet below 1sd

\begin{tabular}{|c|c|c|c|c|c|}
\hline $\begin{array}{l}\text { July } 10,1980 \ldots \\
\text { Aug. } 6 \ldots \ldots\end{array}$ & $\begin{array}{l}1179.36 \\
1185.3\end{array}$ & Sept.10...... & 1191.16 & Dec. $12 \ldots \ldots \ldots$ & 1199.15 \\
\hline
\end{tabular}


Table 3. Continued

94-47-35AAAB1 (1305) MP is top of 2-inch steel pipe 1.4 feet above 1sd. Aquifer: Dakota and Paleozoic Openings: 520-540 feet below 1 sd

\begin{tabular}{|c|c|c|c|c|c|}
\hline Date & $\begin{array}{l}\text { Water } \\
\text { level }\end{array}$ & Date & $\begin{array}{l}\text { Water } \\
\text { level }\end{array}$ & Date & $\begin{array}{l}\text { Water } \\
\text { level }\end{array}$ \\
\hline $\begin{array}{l}\text { Dec. } 11,1978 \ldots \\
\text { Jan. } 3,1979 \ldots \\
\text { Apr. } \\
\text { May } \quad 7 \ldots \ldots \ldots \ldots \\
\text { Ma....... }\end{array}$ & $\begin{array}{l}1159.65 \\
1159.7 \\
1159.9 \\
1160.45\end{array}$ & $\begin{array}{l}\text { June } 10 \ldots \ldots \ldots \\
\text { Aug. } 29 \ldots \ldots \ldots \\
\text { Oct. } 29 \ldots \ldots \ldots \\
\text { Dec. } 13 \ldots \ldots \ldots\end{array}$ & $\begin{array}{l}1156.65 \\
1158.35 \\
1159.40 \\
1159.50\end{array}$ & $\begin{array}{l}\text { Feb. } 1,1980 \ldots \\
\text { Feb. } 28 \ldots \ldots \ldots \\
\text { Plugged and abandoned }\end{array}$ & $\begin{array}{l}1159.85 \\
1160.30\end{array}$ \\
\hline
\end{tabular}

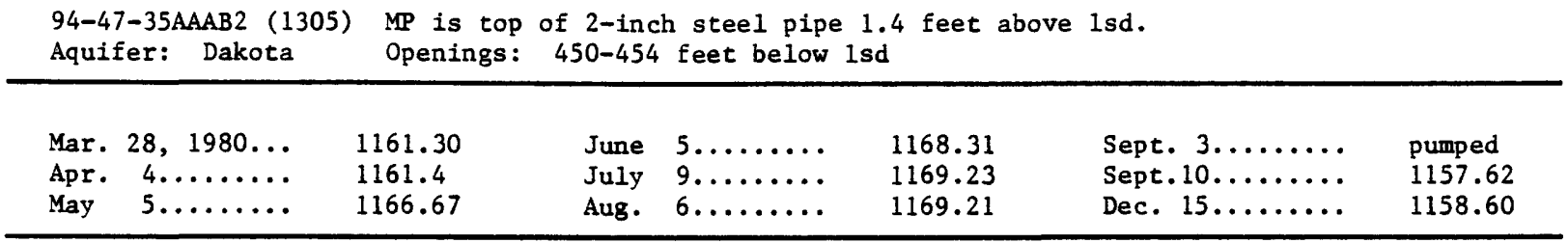

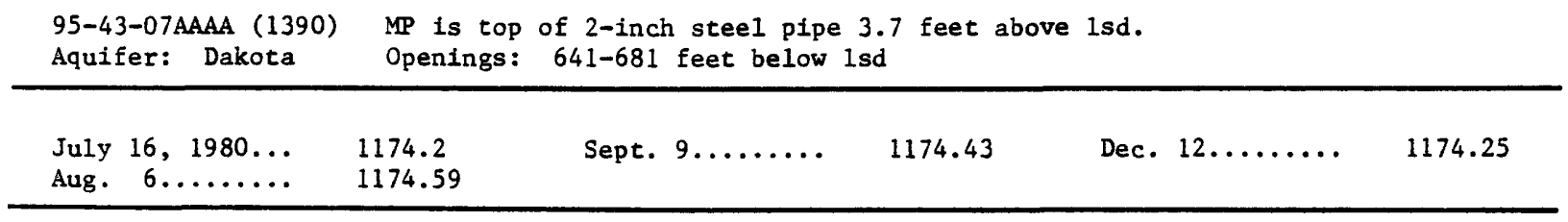

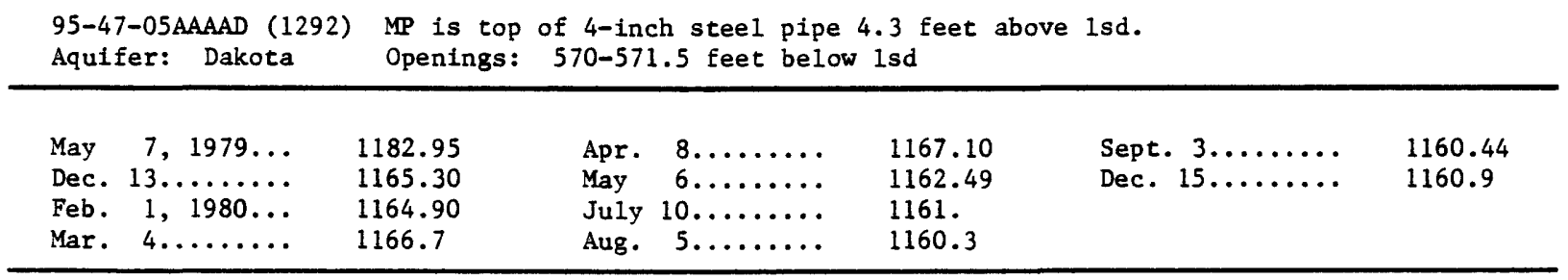

96-40-05DDDA (1560) MP is top of 2-inch steel pipe 4.0 feet above 1sd. Aquifer: Dakota and Paleozoic Openings: 661-701 feet below 1sd

\begin{tabular}{|c|c|c|c|}
\hline July $16,1980 \ldots$ & Sept.10....... & Dec. $12 \ldots \ldots \ldots$ & 1200.20 \\
\hline $\begin{array}{l}96-44-08 \text { ADAA }(137 \\
\text { Aquifer: Dakota }\end{array}$ & \multicolumn{3}{|c|}{$\begin{array}{l}\text { MP is top of 2-inch steel pipe } 3.7 \text { feet above } 1 \text { sd. } \\
\text { Openings: } 647-667 \text { feet below } 1 \text { sd }\end{array}$} \\
\hline Aug. $6,1980 \ldots$ & Sept. $9 \ldots \ldots \ldots$ & Dec. $12 \ldots \ldots \ldots$ & 1179.95 \\
\hline $\begin{array}{l}\text { 98-39-26CDAD1 (16 } \\
\text { Aquifer: Paleozc }\end{array}$ & \multicolumn{2}{|c|}{$\begin{array}{l}\text { of 2-inch steel pipe } 1.47 \text { feet above Isd. } \\
622-662 \text { feet below 1sd }\end{array}$} & \\
\hline $\begin{array}{l}\text { June } 17,1980 \ldots \\
\text { July } 10 \ldots \ldots \ldots\end{array}$ & $\begin{array}{l}\text { Aug. } \quad 5, \ldots \ldots \ldots \\
\text { Sept. } 3 \ldots \ldots \ldots\end{array}$ & Nov. $26 \ldots \ldots \ldots$ & 1203.40 \\
\hline
\end{tabular}


Table 3. Continued

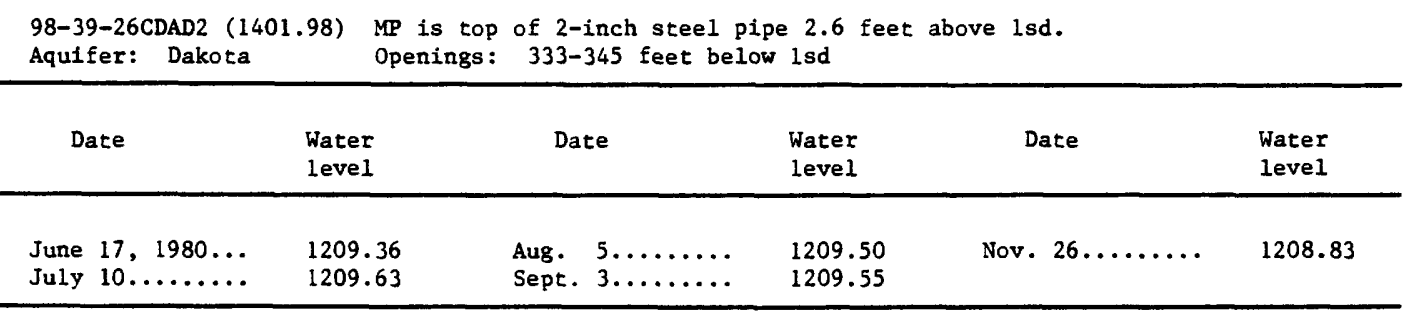

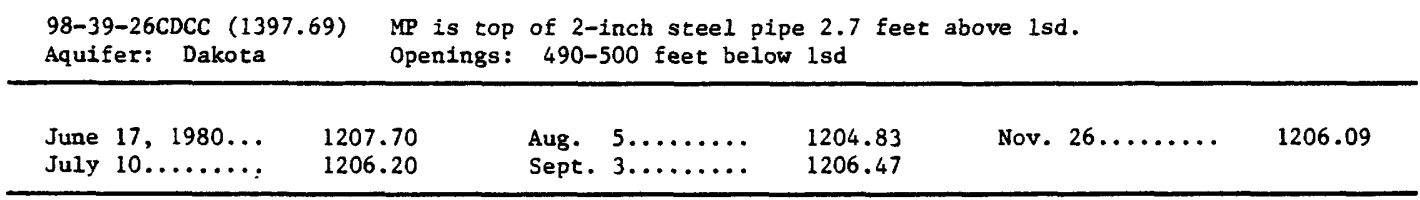

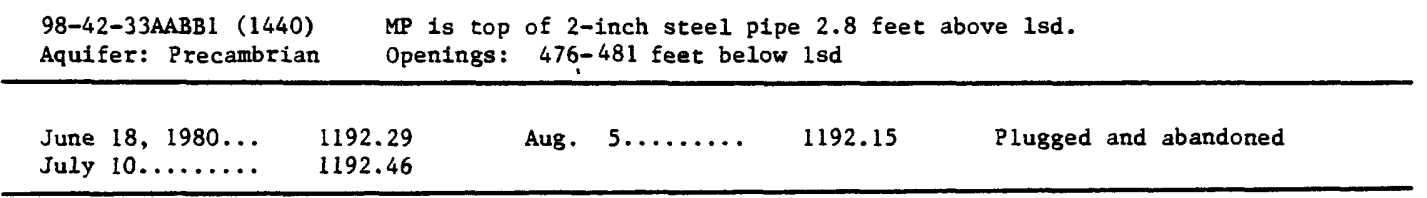

\begin{tabular}{|c|c|}
\hline $\begin{array}{l}98-42-33 A A B B 2 \text { ( } 1440) \\
\text { Aquifer: Quaternary }\end{array}$ & $\begin{array}{l}\text { MP is top of } 2 \text {-inch steel pipe } 2.0 \text { feet above } 1 \text { sd. } \\
\text { Openings: } 310-359 \text { feet below } 1 \text { sd }\end{array}$ \\
\hline Dec. $12,1980 \ldots$ & \\
\hline
\end{tabular}

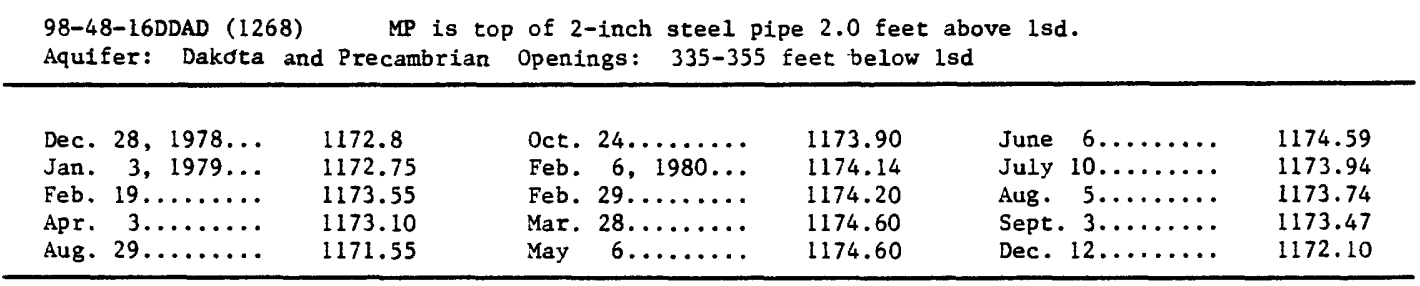

\begin{tabular}{|c|c|c|c|c|c|}
\hline \multicolumn{2}{|c|}{$\begin{array}{l}\text { 100-39-17DCCB } 1(1560) \\
\text { Aquifer: Cambrian }\end{array}$} & \multicolumn{4}{|c|}{$\begin{array}{l}\text { MP is top of } 5-i n c h \text { steel pipe } 3.0 \text { feet above } 1 \text { sd. } \\
\text { Openings: } 770-923 \text { feet below Isd }\end{array}$} \\
\hline $\begin{array}{ll}\text { Dec. } & 8,1978 \ldots \\
\text { Jan. } & 4,1979 \ldots \\
\text { Apr. } & 3 . \ldots \ldots \ldots\end{array}$ & $\begin{array}{l}1208.6 \\
1217.2 \\
1217.35\end{array}$ & $\begin{array}{l}\text { Aug. } 29 \ldots \ldots \ldots \\
\text { Oct. } 30 \ldots \ldots \ldots \ldots \\
\text { Dec. } 13 \ldots \ldots \ldots\end{array}$ & $\begin{array}{l}1217.80 \\
1218.1 \\
1217.20\end{array}$ & $\begin{array}{l}\text { Feb. } \quad 6,1980 \ldots \\
\text { Apr. } 10 . \ldots \ldots \\
\text { Plugged and aband }\end{array}$ & $\begin{array}{l}1217.22 \\
1217.75 \\
\text { ed }\end{array}$ \\
\hline \multicolumn{2}{|c|}{$\begin{array}{l}\text { 100-39-17DCCB2 (1560) } \\
\text { Aquifer: Dakota }\end{array}$} & \multicolumn{4}{|c|}{$\begin{array}{l}\text { of 5-inch steel pipe } 3.0 \text { feet above } 1 \text { s } 4 \text {. } \\
680-700 \text { feet below } 1 \text { sd }\end{array}$} \\
\hline $\begin{array}{l}\text { July } 10,1980 \ldots \\
\text { Aug. } \quad 5 \ldots \ldots\end{array}$ & $\begin{array}{l}1217.6 \\
1218.2\end{array}$ & Sept. $9 \ldots \ldots \ldots$ & 1217.50 & Dec. $10 \ldots \ldots \ldots$ & 1216.7 \\
\hline
\end{tabular}


Table 3. Continued

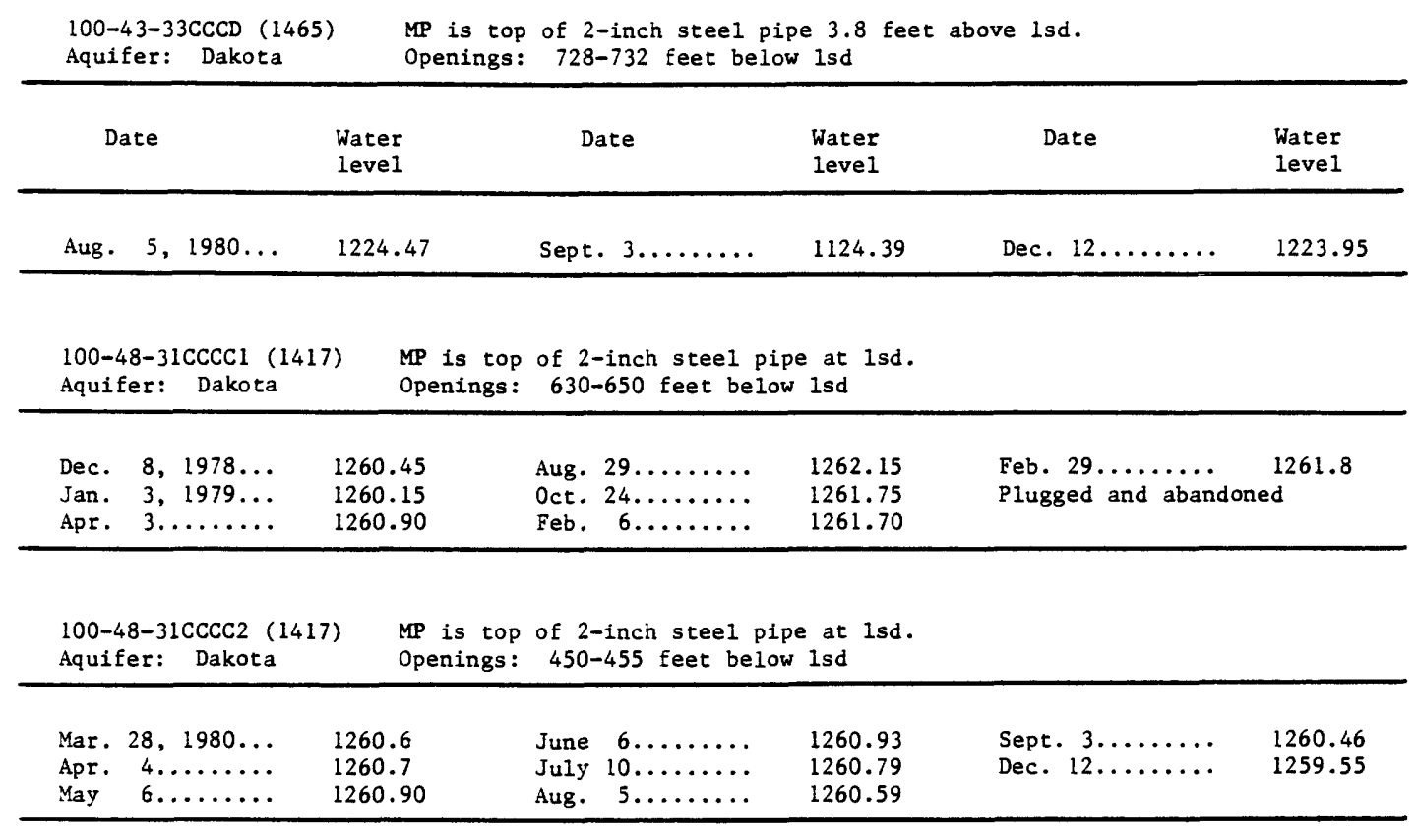


Table 4. Summary of pumping test results in the study areas

\begin{tabular}{|c|c|c|c|}
\hline Location & $\begin{array}{c}\text { Transmissivity } \\
\text { (feet squared } \\
\text { per day) }\end{array}$ & $\begin{array}{c}\text { Average Thickness } \\
\text { of Dakota Aquifer } \\
\text { (feet) }\end{array}$ & $\begin{array}{c}\text { Average Hydraulic } \\
\text { Conductivity } \\
\text { (feet per day) }\end{array}$ \\
\hline $\begin{array}{c}\text { Hosteng Irrigation Site } \\
87-35-30\end{array}$ & 4600 & 124 & 37 \\
\hline $\begin{array}{c}\text { Ritz Irrigation Site } \\
92-47-31\end{array}$ & 7600 & 157 & 48 \\
\hline $\begin{array}{c}\text { Southern Sioux County Rural } \\
\text { Water System, Inc. } \\
93-45-04\end{array}$ & 7400 & 148 & 50 \\
\hline $\begin{aligned} \text { Hansen } & \text { Irrigation Site } \\
& 97-46-28\end{aligned}$ & 3900 & 89 & 44 \\
\hline Hibbing $\begin{array}{c}\text { Irrigation Site } \\
98-39-26\end{array}$ & 6400 & 162 & 40 \\
\hline
\end{tabular}


Table 5. Selected chemical analyses

[Station name includes loction and local name of well. Temperature is in degrees Celsius (DEG C). Most constituents are measured in milligrams per liter $(\mathrm{MG} / \mathrm{L})$. Iron and manganese are measured in micrograms per liter (UG/L). Gross alpha is measured in micrograms per liter (UG/L)

\section{STATION NAME}

$09240 W 35 B B B B$ $09241 W 05 C A C D$ 09241 WO5CBDA $09241 W 12 C C D$ 09244 WO5AA

$09245 W 01 D A B B$ $09245 W 02 C B C B$ 09245 WO9CAAD $09245 W 20 B B A B$ $09245 W 30 B C B A$

$09248 W 06 D D D A$ 09335 WI 3ADAA $09335 W 19 D C B B$ $09337 W 36 C A B C$ $09342 W 36 D C C D$

09346W12DDDD $09431 W 13 A C C C$ $09433 W 25 A B A$ $09439 W 07 C A B$ $09439 W 07 C A B$

$09439 W 26 E A D B$ $09442 W 090 D D D$ $09444 W 05 A A C B$ $09445 W 17 A A C B$ $09445 \mathrm{~W} 17 \mathrm{AACD}$

09446 WO7OAD 09446 W07DDAB $09447 W 35 A A A B$ 09543 WOTAAAA 09547 WO5AAAA

$09634 W 180 C A C$ $09634 W 18 D D B B$ $09641 W 360 A D$ 09644 W08ADAA $09739 W 32 A C C$

$09739 W 32 A C C$ $09742 W 30 A C D B$ $09745 W 26 C B A A$ $09745 W 26 C B A A$ $09746 W 28 D B A D$

09B 37W15DDDD $09839 W 26 C D A D$ $09839 W 26 C D C C$ $09842 W 33 A A B B$ $09847 W 18 A A C$

$09847 W 18 A C D C$ $09847 W 18 B D B$ $09848 W 160 D A D$ $09942 W 13 A C C$ $09942 W 13 A C C B$

$09942 W 130 B B C$ $10039 W 170 \mathrm{CCC}$ $10043 W 33 C C C D$ $10048 \mathrm{~W} 31 \mathrm{CCCC}$

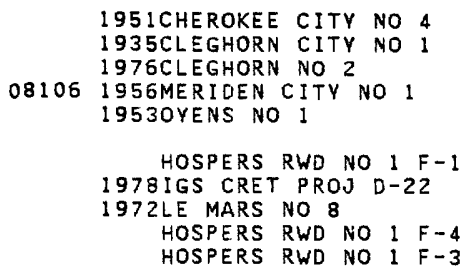

1951 CHEROKEE CITY NO 4 $1935 \mathrm{CLEGHORN} \mathrm{CITY} \mathrm{NO}$ 1976 CLEGHORN NO 2 08106 1956MERIDEN CITY NO 1 1953 OYENS NO 1

257361979 IGS CRET PROJ D-35 25737 1979IGS CRET PROJ $0-36$ 2552819791 IGS CRET PROJ L-27 1935 REMBRANDT TOWN WELL CHEROKEE RWO MC 1

245561977 IGS CRET PROJ 0-2 $035951949 W E S T$ BEND TOWN WELL 028631947 MALLARD CITY WELL $\$ 2$ 001101930 SUTHERLAND TOWN WELL 060451953 SUTHERLAND 3

24557 1977IGS CRET PROJ D-3 25964 1980.IGS CRET PROJ 0-42 1968 ORANGE CITY WELL NO 6 1975 TOWN OF MAURICE NO 4 148601962 TOWN OF MAURICE NO 3

023101946 IRETON TOWN WELL 1967 IRETON CITY WELL NO 4

$253211980 I G S$ CRET PROJ 0-18

25965 1980IGS CRET PROJ 0-43 1980 IGS CRET PROJ $0-43$
1978 IGS CRET PROJ $0-7$

086301957 RUTHVEN *5

019601944 RUTHVEN CITY \#4

079301956 PRIMGHAR TOWN WELL

2594119801 GS CRET PROJ D-44
008171938 HARTLEY TOWN WELL NO

12222196 OHARTLEY TOWN WELL

158181963 SHELDON TOWN WELL

104341959 HULL CITY WELL. NO 4

24520 1977LOREN HANSEN IRRIG STUDY

1980 IGS CRET PROJ $0-46$

25B98 1980 IGS CRET PROJ 0-38

258991980 IGS CRET PROJ $0-39$ $1980 I G S$ CRET PROJ D-4O

159261963 INWOOD TOWN WELL 3

1966 INWOOD TOWN WELL NO 4

013441940 INWOOD TOWN WELL 1

25523197 IGS LRET PROJ D-20

02272 1940SIBLEY TOWN WELL 194 ESIBLEY TO'NN WELL NO 2

122231960 IBLEY CITY WE:L NO 3

25108 1978IGS CRET PROJ I-13

259651980 IGS CRET PROJ D-45

253131978 IGS CRET PROJ D-19

\begin{tabular}{|c|c|c|c|c|c|c|c|}
\hline $\begin{array}{c}\text { DATE } \\
\text { OF } \\
\text { SAMPLE }\end{array}$ & $\begin{array}{l}\text { SOLIDS, } \\
\text { RESIDUE } \\
\text { AT } 105 \\
\text { DEG. C, } \\
\text { DIS- } \\
\text { SOLVED } \\
\text { (MG/L) }\end{array}$ & $\begin{array}{l}\text { SPE- } \\
\text { CIFIC } \\
\text { CON- } \\
\text { DUCT- } \\
\text { ANCE } \\
\text { (MICRO- } \\
\text { MHOS ) }\end{array}$ & $\begin{array}{l}\text { TEMPER- } \\
\text { ATURE, } \\
\text { WATER } \\
\{\text { DEG C }\}\end{array}$ & $\begin{array}{l}\text { HARD- } \\
\text { NESS } \\
\text { (MG/L } \\
\text { AS } \\
\text { CACO3) }\end{array}$ & $\begin{array}{l}\text { SODIUM } \\
\text { AD- } \\
\text { SORP- } \\
\text { TION } \\
\text { RATIO }\end{array}$ & $\begin{array}{l}\text { IRON, } \\
\text { DIS- } \\
\text { SOLVED } \\
\text { (UG / } \\
\text { AS FE) }\end{array}$ & $\begin{array}{l}\text { CALCIUM } \\
\text { DIS- } \\
\text { SOLVED } \\
\text { (MG/L } \\
\text { AS CA) }\end{array}$ \\
\hline $\begin{array}{l}77-05-03 \\
76-07-30 \\
76-07-30 \\
74-08-16 \\
76-12-08\end{array}$ & $\begin{array}{r}576 \\
1020 \\
1050 \\
1870 \\
460\end{array}$ & $\begin{array}{l}820 \\
1400 \\
1400 \\
2100 \\
680\end{array}$ & $\begin{array}{r}-- \\
-- \\
10.0\end{array}$ & $\begin{array}{r}400 \\
560 \\
600 \\
1090 \\
375\end{array}$ & $\begin{array}{r}.7 \\
2.0 \\
2.1 \\
1.6 \\
.3\end{array}$ & $\begin{array}{r}1100 \\
820 \\
1100 \\
1400 \\
1200\end{array}$ & $\begin{array}{l}110 \\
140 \\
150 \\
290 \\
100\end{array}$ \\
\hline $\begin{array}{l}77-03-16 \\
80-03-12 \\
77-05-05 \\
77-03-16 \\
77-03-16\end{array}$ & $\begin{array}{r}840 \\
279 \\
1060 \\
2600 \\
712\end{array}$ & $\begin{array}{r}1200 \\
540 \\
1300 \\
2800 \\
1100\end{array}$ & $\begin{array}{r}7.0 \\
11.0 \\
=- \\
5.0 \\
7.0\end{array}$ & $\begin{array}{r}598 \\
250 \\
670 \\
1390 \\
497\end{array}$ & $\begin{array}{r}.6 \\
.4 \\
1.1 \\
2.2 \\
.9\end{array}$ & $\begin{array}{r}3000 \\
30 \\
850 \\
2300 \\
2400\end{array}$ & $\begin{array}{r}160 \\
72 \\
180 \\
360 \\
140\end{array}$ \\
\hline $\begin{array}{l}80-04-23 \\
80-01-30 \\
80-01-30 \\
79-02-08 \\
77-06-20\end{array}$ & $\begin{array}{l}1880 \\
1220 \\
1940 \\
1530 \\
1260\end{array}$ & $\begin{array}{l}2200 \\
1500 \\
1800 \\
1800 \\
1600\end{array}$ & $\begin{array}{r}12.0 \\
10.0 \\
10.0 \\
12.0\end{array}$ & $\begin{array}{l}980 \\
530 \\
970 \\
970 \\
680\end{array}$ & $\begin{array}{r}2.2 \\
2.2 \\
.2 \\
1.0 \\
1.8\end{array}$ & $\begin{array}{l}360 \\
3600 \\
8800 \\
2900 \\
1900\end{array}$ & $\begin{array}{l}250 \\
140 \\
260 \\
250 \\
180\end{array}$ \\
\hline $\begin{array}{l}80-03-26 \\
76-04-12 \\
77-08-29 \\
74-05-08 \\
77-07-26\end{array}$ & $\begin{array}{l}439 \\
1000 \\
1140 \\
1940 \\
2030\end{array}$ & $\begin{array}{l}610 \\
1300 \\
1400 \\
2200 \\
2200\end{array}$ & $\begin{array}{r}-- \\
10.0 \\
13.0 \\
-- \\
--\end{array}$ & $\begin{array}{r}330 \\
652 \\
751 \\
1110 \\
1220\end{array}$ & $\begin{array}{r}.2 \\
.9 \\
1.1 \\
1.6 \\
1.2\end{array}$ & $\begin{array}{r}50 \\
4300 \\
15000 \\
2900 \\
4000\end{array}$ & $\begin{array}{r}97 \\
160 \\
180 \\
290 \\
320\end{array}$ \\
\hline $\begin{array}{l}00-04-07 \\
80-06-30 \\
76-02-24 \\
76-12-08 \\
74-05-23\end{array}$ & $\begin{array}{r}1550 \\
2250 \\
1230 \\
2420 \\
515\end{array}$ & $\begin{array}{r}1800 \\
2300 \\
1600 \\
2700 \\
820\end{array}$ & $\begin{array}{r}11.0 \\
13.0 \\
10.0 \\
-0\end{array}$ & $\begin{array}{r}1000 \\
1160 \\
790 \\
1400 \\
480\end{array}$ & $\begin{array}{r}1.1 \\
.5 \\
1.2 \\
1.8 \\
.4\end{array}$ & $\begin{array}{r}110 \\
110 \\
16000 \\
1700 \\
260\end{array}$ & $\begin{array}{l}280 \\
300 \\
200 \\
350 \\
110\end{array}$ \\
\hline $\begin{array}{l}77-04-20 \\
77-04-20 \\
80-03-27 \\
80-07-10 \\
80-04-24\end{array}$ & $\begin{array}{l}1140 \\
1280 \\
2070 \\
2330 \\
2000\end{array}$ & $\begin{array}{l}1400 \\
1600 \\
2400 \\
2600 \\
2300\end{array}$ & 11.0 & $\begin{array}{r}727 \\
800 \\
1100 \\
960 \\
650\end{array}$ & $\begin{array}{l}1.0 \\
1.1 \\
2.0 \\
3.6 \\
3.0\end{array}$ & $\begin{array}{r}1300 \\
2800 \\
790 \\
30 \\
60\end{array}$ & $\begin{array}{l}170 \\
190 \\
260 \\
320 \\
260\end{array}$ \\
\hline $\begin{array}{l}76-03-17 \\
76-03-17 \\
75-07-29 \\
80-07-18 \\
73-10-12\end{array}$ & $\begin{array}{l}1250 \\
1230 \\
2070 \\
2580 \\
2270\end{array}$ & $\begin{array}{l}1600 \\
1500 \\
2300 \\
2800 \\
2600\end{array}$ & $\begin{array}{r}-- \\
-- \\
13.0 \\
10.0\end{array}$ & $\begin{array}{l}788 \\
771 \\
1190 \\
1200 \\
1420\end{array}$ & $\begin{array}{l}1.3 \\
1.4 \\
1.8 \\
2.8 \\
1.5\end{array}$ & $\begin{array}{l}3500 \\
6200 \\
1700 \\
3800 \\
5300\end{array}$ & $\begin{array}{l}200 \\
190 \\
300 \\
290 \\
370\end{array}$ \\
\hline $\begin{array}{l}76-08-16 \\
76-04-09 \\
76-07-01 \\
76-07-01 \\
78-01-17\end{array}$ & $\begin{array}{l}2190 \\
2190 \\
2420 \\
2290 \\
1460\end{array}$ & $\begin{array}{l}2400 \\
2400 \\
2700 \\
2200 \\
1700\end{array}$ & $\begin{array}{r}12.0 \\
12.0 \\
12.0 \\
9.0\end{array}$ & $\begin{array}{r}1370 \\
1200 \\
1320 \\
1260 \\
544\end{array}$ & $\begin{array}{l}1.1 \\
1.7 \\
-- \\
2.3 \\
1.4\end{array}$ & $\begin{array}{l}1400 \\
1700 \\
1400 \\
3100 \\
2000\end{array}$ & $\begin{array}{l}350 \\
300 \\
300 \\
280 \\
210\end{array}$ \\
\hline $\begin{array}{l}80-08-27 \\
80-05-21 \\
80-05-30 \\
80-10-02 \\
74-04-18\end{array}$ & $\begin{array}{l}1350 \\
1680 \\
2090 \\
2830 \\
1040\end{array}$ & $\begin{array}{l}1600 \\
2000 \\
2300 \\
2900 \\
1300\end{array}$ & $\begin{array}{l}11.0 \\
12.0 \\
11.0 \\
11.0 \\
12.7\end{array}$ & $\begin{array}{r}810 \\
920 \\
1200 \\
1490 \\
570\end{array}$ & $\begin{array}{l}1.3 \\
2.0 \\
1.9 \\
3.0 \\
1.4\end{array}$ & $\begin{array}{r}30 \\
140 \\
400 \\
40 \\
4800\end{array}$ & $\begin{array}{l}220 \\
250 \\
300 \\
340 \\
140\end{array}$ \\
\hline $\begin{array}{l}74-04-18 \\
75-11-03 \\
75-05-22 \\
77-06-04 \\
77-00-04\end{array}$ & $\begin{array}{r}1030 \\
1050 \\
750 \\
2320 \\
2310\end{array}$ & $\begin{array}{l}1300 \\
1300 \\
1000 \\
2300 \\
2900\end{array}$ & $\begin{array}{r}14.4 \\
3.0 \\
23.0 \\
13.0 \\
-.0\end{array}$ & $\begin{array}{r}650 \\
630 \\
350 \\
1510 \\
1600\end{array}$ & $\begin{array}{l}1.0 \\
2.2 \\
1.9 \\
\therefore .9 \\
\therefore .2\end{array}$ & $\begin{array}{r}1600 \\
30 \\
1400 \\
440 \\
860\end{array}$ & $\begin{array}{r}160 \\
150 \\
93 \\
380 \\
390\end{array}$ \\
\hline $\begin{array}{l}77-05-24 \\
60-05-01 \\
80-05-01 \\
80-03-29\end{array}$ & $\begin{array}{r}2310 \\
2320 \\
14 \div 0 \\
709\end{array}$ & $\begin{array}{l}2900 \\
2300 \\
1800 \\
100 .\end{array}$ & $\begin{array}{l}10.0 \\
11.0 \\
12.0 \\
11.0\end{array}$ & $\begin{array}{l}1520 \\
.300 \\
700 \\
480\end{array}$ & $\begin{array}{r}2.2 \\
1.4 \\
2.3 \\
.7\end{array}$ & $\begin{array}{r}2000 \\
70 \\
50 \\
60\end{array}$ & $\begin{array}{l}380 \\
340 \\
180 \\
120\end{array}$ \\
\hline
\end{tabular}


of water from the Dakota aquifer

equivalent of naturally occuring uranium (U-NAT). Radium is measured in picocuries per liter (PCI/L). Gross beta is measured in picocuiries per liter (PCI/L) equivalent of cesium-137]
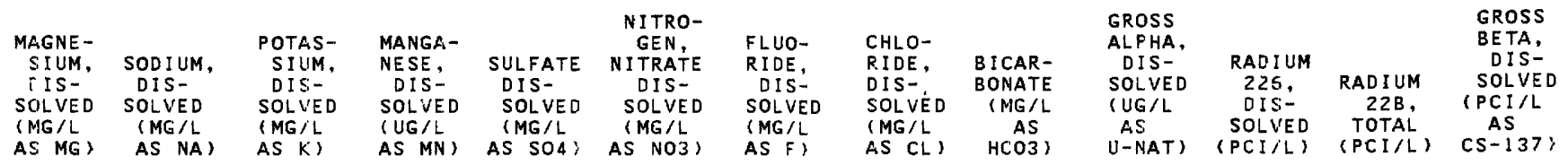

96

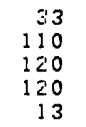

E.B
10
10
14
4.2

280
170
200
500
420

160
460
480
970
74

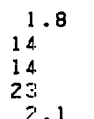

620
40
110
720
490

200
42
500
1400
150

1.1
$<.10$
.20
$<.10$

35
17
6.4
190
4.7

2

150

160
120
15
75
110

23
10
70
5.5
1.6

490
230
340

340
550
90

940
410

760
750

750
620

$\begin{array}{rrr}7.1 & 100 & 96 \\ 15.5 & 460 & 380 \\ 4.5 & 100 & 390\end{array}$

10.5

100
550

390
1000

1000

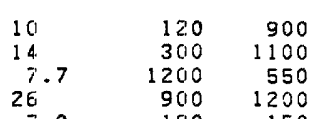

81
150
76

76
150

150
18

26.0

900
180

1200
150

15
16
22
21
18

210
240
270
120

510
590

1100

1200
1000

$\begin{array}{rl}83 & 6.2 \\ 86 & 5.1 \\ 140 & 13 \\ 230 & 17 \\ 130 & 13\end{array}$

280

540

$\begin{array}{rr}300 & 550 \\ 390 & 1100 \\ 240 & 1400\end{array}$

$\begin{array}{ll}240 & 1400 \\ 450 & 1200\end{array}$

14
21
23
23
18

580

1100

$130 \quad 1200$

$\begin{array}{ll}160 & 1400 \\ 180 & 1200\end{array}$

$\begin{array}{rr}180 & 1200 \\ 310 & 720\end{array}$

$\begin{array}{rr}6.7 & 230 \\ 9.4 & 690 \\ 9.6 & 610 \\ 16 & 520 \\ 15 & 90\end{array}$

650

820

1100
1600

1500
480

11

500
460

政

1300

100
200

15
30
$\vdots$
30
3

280

20

ci. 0

34

1600

1600
1100
700

700
$3 \geq 0$
$<.10$
.20
.70
$<.10$

.10
.10

.10
.20

.20
3.6

$<.10$

.10
$<.10$

C. 10

C.10
6.0
.50

.50

.50
.20

.60
$<.10$

2.8

.10

<. 10

10
$<.10$

2.4
.40

1.80
1.0

1.0
$<.10$

.20

4.7

1.10

12.

$13^{.40}$

.7
.9
1.0
.5
3

$\begin{array}{rr}1.0 & 361 \\ 3.5 & 397 \\ 4.0 & 403 \\ 14 & 427\end{array}$

1.0

.3
3.4
.9
.5
.3

$110 \quad 368$

$\begin{array}{rr}110 & 302 \\ 8.0 & 351 \\ 20 & 434 \\ 100 & 340\end{array}$

100

$64 \quad 383$

1.8
.7
.8
.8
1.2

560

5.0
2.0

2.0
5.0

$\begin{array}{rr}6.5 & 315 \\ 11 & 439 \\ 3.0 & 567 \\ 8.0 & 371\end{array}$

8.0
3.5

$\begin{array}{ll}2.0 & 396 \\ 16 & 405 \\ 53 & 371 \\ 26 & 388\end{array}$

$\begin{array}{rr}26 & 388 \\ 1.0 & 388\end{array}$

$5.0 \quad 394$

$\begin{array}{rr}5.0 & 416 \\ 19 & 392\end{array}$

19

25
64

415

$\begin{array}{ll}4.0 & 421 \\ 4.5 & 425 \\ 21 & 437 \\ 33 & 372\end{array}$

33
37

32
13

13
27

27
28
22

$\begin{array}{cc}2.5 & 368 \\ 30 & 361 \\ 40 & 411 \\ 23 & 367 \\ 6.0 & 327 \\ 5.5 & 333 \\ 9.0 & 332 \\ 14 & 313 \\ 30 & 374 \\ 34 & 388 \\ & \\ 31 & 400 \\ 44 & 432 \\ 7.0 & 305 \\ 9.0 & 321\end{array}$

5.2
.0
.0
4.9
.0

14

14
2.1
7.2
4.5

4.5
4.5

6.1

3.9
4.6

2. 3

4.7

3. 2

3.2
3.0
2.8

2.8
.9

8.7

2.9

3.4

4.4
2.3

2.3
9.1

5.5

3.0
$17^{.4}$
8.7
.-

--
--
2.1
2.6

$<.10$

$<.10$

2.3

$\because 10$

$<.10$

$<.10$
$12^{.0}$

1.2

9.9

.5
9.5
5.6
11.6
4.4

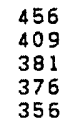

368

$31 \frac{1}{367}$

1.2

1.2
.7
.8

1.4

11

2.4

$$
3 .
$$

3.0
1.8

$--$

.3
2.7
7.6
..-
$1 . B$
---
1.4
--

.5
1.1
4.3
.6
.4

$\begin{array}{lr}-- & 9.0 \\ -- & 9.0 \\ -- & 13 \\ -- & 6.0 \\ - & 3.0\end{array}$

$$
\text { - } 3.0
$$

$2.1 \quad 6.0$

$\begin{array}{ll}12 \\ -1 & 11\end{array}$

$\begin{array}{ll}\ldots & 5.0 \\ \ldots & 3.0\end{array}$

. 621

$\begin{array}{ll}.6 & 21 \\ -0 & 16 \\ .8 & 20 \\ -. & 11\end{array}$

$\begin{array}{ll}-2 & 11 \\ -- & 12\end{array}$

$3.0 \quad 5.0$

$\begin{array}{ll}-- & 19 \\ -- & 5.0\end{array}$

.$-6 \quad 19$

$\begin{array}{ll}-- & 8 . \\ -- & 26 \\ -- & 15\end{array}$

$\begin{array}{ll}-- & 14 \\ -- & 17\end{array}$

$\begin{array}{ll}3.4 & 11 \\ 5.7 & 31 \\ 4.9 & 15\end{array}$

$\begin{array}{ll}- & 9.6 \\ -- & 3.4 \\ 5.9 & 36 \\ -- & 16\end{array}$

$--\quad 36$

$\begin{array}{rr}-- & 47 \\ -5 & 24\end{array}$

$\begin{array}{ll}3.5 & 24 \\ 4.7 & 36\end{array}$

$--13$

$\begin{array}{ll}.6 & .0\end{array}$

$1.7 \quad 15$

$\begin{array}{ll}-- & 28 \\ -- & 15\end{array}$

$--\quad 20^{--}$

$\begin{array}{rr}2.0 \\ .8 & 20^{\circ}\end{array}$
-- 11 
Table 5. Continued

STATION NAME $08635 W 11 D C D C$ $08635 W 24 B B A$ O8635W2 4 SBR $08735 W 3000 C D$

$08739 W 23 A C B D$ C874OWIADDD $O B 744 W ! 5 C B B B$ $06747 \mathrm{~W} 35 E C D$. O8B44W06BAAB

$02938 W 2 E A B A A$ $03938 W 26 A C C C$ $08940 W 35 B B B$ $08940 W 35 B B B C$ $08942 W 34 C D C$

$08944 W 20 D C D C$ $08946 \mathrm{~W} 36 \mathrm{EBDC}$ $08947 W 2 B B B C C$ $08947 W 29 A A B D$ O8947W29ABDC

$08947 W 29 A C A A$ $08947 W 294 D A B$ $08947 W 29 A D B A$ $08947 W 29 C A D A$ O8947W29CCCA

$08947 W 25 C C D A$ $08947 W 29 C D C D$ $08947 W 290 C C B$ $08947 W 350 A A B$ O8947W35DAAD

$08947 W 35 D A D B$ O8947W35OADD O9038W16DDDD O9O4 DWC GEDCD O9041W1IADAD

$09046 W 17 A C A C$ $09135 W 26 B C C C$ $09137 W 02 C B A$ $09138 W 26 A C A$ $09138 W 26 B A C A$

O9I39WOIADAD O9139W1 OADDA $09139 W 10500 B$ $09139 W 10 D B B B$ $09140 W 03 E A C B$

$09142 W 160000$ $09232 W 31 C D A A$ $09240 W 10 E D D D$ $09240 W 26 C B D$ $09240 W 26 C C D D$

$09240 W 27 D A C C$ O924OW2TDACC
$029751947 F A R N H A M V I L L E$ WELL NO 3 1980 GRANITE CITY OBS D-48E $015841942 T O W N$ OF AUBURN NO 2 062101952 TOWN OF AUBURN NO 3 $24550 \quad 1977$ HOSTENG $* 2$

19840 1967ARTHUR TOWN NO 4 07264 !955IDA GROVE NC 3

257351979 IGS CRET PROJ O-34 1949 SALIY NO 1

255941979 ISS D-33NW:A PROJECT

$010761939 T O W N$ OF SCHELLER NO 1 09380 1957TOWN OF SEHALLER NO 3 05i20 19ELHOLSTEIN TOWIA NO 4 OC567 1937 HOLSTEIN TOWN NO 3 OBB54 I957CORRECTICNVILLE NO 2 DW

255931979 IGS CRET PROJ D-32

255911979 IGS CRET PROJ D-30 1949 SIOUX CITY NO 20 PERRY C 1919 SIOUX CITY NO 16 PERRY 1969 SIOUX CITY NO 11-MAIN ST

1911 SIOUY CITV NO 14-PERRY C 1926 SIOUY CITY NO 17-PERRY C 1941 ISIOUX CITY NO 18-PERRY C 1971 SIOUX CITY NO 5-MO RIVEP 1971SIOUX CITV NO 4-MO RIVER

1971SIOLX CITYNO 3-MO RIVER 1971 SIOUX CITY NO 2-MO FIVER 1971 SIOUX CITY NO I-MO RIVER 1964 SIOUX C!TY NO 2-SP PARK 1965 SIOUX CITY NO 3-SP PARK

1969SIOUX CITY NO 4-SP PARK 1956 SIOUX CITY NO 1-SP PARK

$255261979 I G S$ CRET PROJ D-25 (DAK)

255211979165 CRET PROJ D-

1974HINON NO 4

$25525197916 S$ CRET PROJ D-24

081041955 TRUESDALE CITY NO

$141651963 A L T A$ CITY NO 4 $1950 A L T A$ TOWN WELL NO 3

255291979 IGS CRET PROJ D-29 1961 AURELIA NO 3 $1972 A U R E L I A$ CITY NO 4

006961937 AURELIA CITY 1965 CHEROKEE NO 5

25114 1978IGS CRET PROJ D-11

015491941 POCAHONTAS 1

245691977 I S CRET FROJ

12538 196OMENTAL HEALTH VO $\angle$ 1952 CHEROKEE NO 3

1921 MENTAL HEALTH 1942MENTA: HEALTW

\begin{tabular}{|c|c|c|c|c|c|c|c|}
\hline $\begin{array}{c}\text { DATE } \\
\text { OF } \\
\text { SAMPLE }\end{array}$ & $\begin{array}{l}\text { SOLIOS } \\
\text { RESIOUE } \\
\text { AT IOS } \\
\text { OEG.C. } \\
\text { OIS- } \\
\text { SOLVES } \\
\text { (MGIL) }\end{array}$ & $\begin{array}{l}\text { SPE- } \\
\text { CIFIC } \\
\text { CON- } \\
\text { SUCT- } \\
\text { ANCE } \\
\text { SMICRO- } \\
\text { MHOS: }\end{array}$ & $\begin{array}{l}\text { TEMPER- } \\
\text { ATURE, } \\
\text { W:TER } \\
\text { (DEG C) }\end{array}$ & $\begin{array}{l}\text { HARD- } \\
\text { NESS } \\
\text { (MG/L } \\
\text { AS } \\
\text { CACO3) }\end{array}$ & $\begin{array}{l}\text { SODIUM } \\
\text { AD- } \\
\text { SORP- } \\
\text { TION } \\
\text { RATIO }\end{array}$ & $\begin{array}{l}\text { IRON, } \\
\text { OIS- } \\
\text { SOLVEO } \\
\text { (UG L } \\
\text { ASS FE) }\end{array}$ & $\begin{array}{l}\text { CALCIUM } \\
\text { SIS- } \\
\text { SOLVED } \\
\text { IMGIL } \\
\text { AS CA }\end{array}$ \\
\hline $\begin{array}{l}77-04-12 \\
80-10-14 \\
76-12-15 \\
76-12-15 \\
78-07-28\end{array}$ & $\begin{array}{r}848 \\
528 \\
1060 \\
1130 \\
516\end{array}$ & $\begin{array}{r}1200 \\
790 \\
1300 \\
1400 \\
820\end{array}$ & $\begin{array}{l}11.0 \\
10.0 \\
10.0 \\
11.0\end{array}$ & $\begin{array}{l}510 \\
450 \\
720 \\
780 \\
420\end{array}$ & $\begin{array}{r}1.2 \\
.2 \\
1.1 \\
1.2 \\
.4\end{array}$ & $\begin{array}{r}450 \\
20 \\
5600 \\
4900 \\
1900\end{array}$ & $\begin{array}{l}110 \\
120 \\
180 \\
200 \\
110\end{array}$ \\
\hline $\begin{array}{l}76-11-29 \\
77-05-15 \\
30-04-23 \\
7=-08-11 \\
75-10-15\end{array}$ & $\begin{array}{r}1580 \\
557 \\
35 ! \\
550 \\
377\end{array}$ & $\begin{array}{r}2000 \\
830 \\
550 \\
880 \\
570\end{array}$ & $\begin{array}{r}10.0 \\
11.0 \\
13.0\end{array}$ & $\begin{array}{l}870 \\
410 \\
320 \\
450 \\
280\end{array}$ & $\begin{array}{r}2.1 \\
.4 \\
.3 \\
.5 \\
.3\end{array}$ & $\begin{array}{r}3700 \\
10 \\
1600 \\
5200 \\
2400\end{array}$ & $\begin{array}{r}230 \\
120 \\
90 \\
110 \\
80\end{array}$ \\
\hline $\begin{array}{l}75-2:-10 \\
75-11-10 \\
74-04-25 \\
77-05-25 \\
75-05-12\end{array}$ & $\begin{array}{l}2730 \\
2420 \\
1250 \\
1510 \\
1454\end{array}$ & $\begin{array}{l}2900 \\
2700 \\
1600 \\
1800 \\
1700\end{array}$ & $\begin{array}{r}14.0 \\
14.0 \\
12.2 \\
-- \\
--\end{array}$ & $\begin{array}{r}1400 \\
1200 \\
780 \\
860 \\
780\end{array}$ & $\begin{array}{l}2.4 \\
2.5 \\
1.5 \\
2.4 \\
2.0\end{array}$ & $\begin{array}{r}5500 \\
240 \\
900 \\
1800 \\
1500\end{array}$ & $\begin{array}{l}3=0 \\
300 \\
210 \\
200 \\
210\end{array}$ \\
\hline $\begin{array}{l}79-10-16 \\
80-04-09 \\
74-10-22 \\
74-10-22 \\
77-08-02\end{array}$ & $\begin{array}{l}447 \\
378 \\
891 \\
759 \\
796\end{array}$ & $\begin{array}{r}570 \\
620 \\
1300 \\
1100 \\
1100\end{array}$ & $\begin{array}{l}11.0 \\
12.0 \\
12.0 \\
12.0 \\
13.0\end{array}$ & $\begin{array}{l}290 \\
320 \\
590 \\
490 \\
520\end{array}$ & $\begin{array}{r}.3 \\
.2 \\
1.1 \\
1.1 \\
.9\end{array}$ & $\begin{array}{r}1300 \\
70 \\
510 \\
330 \\
620\end{array}$ & $\begin{array}{r}87 \\
93 \\
150 \\
130 \\
140\end{array}$ \\
\hline $\begin{array}{l}74-10-22 \\
77-08-02 \\
74-10-22 \\
73-04-05 \\
73-04-05\end{array}$ & $\begin{array}{l}628 \\
788 \\
715 \\
549 \\
490\end{array}$ & $\begin{array}{r}930 \\
1200 \\
1100 \\
870 \\
830\end{array}$ & $\begin{array}{l}11.5 \\
13.0 \\
12.0 \\
10.0 \\
10.0\end{array}$ & $\begin{array}{l}390 \\
530 \\
530 \\
350 \\
350\end{array}$ & $\begin{array}{r}1.2 \\
.9 \\
.8 \\
2.3 \\
1.1\end{array}$ & $\begin{array}{r}450 \\
350 \\
10 \\
460 \\
410\end{array}$ & $\begin{array}{r}100 \\
140 \\
130 \\
94 \\
93\end{array}$ \\
\hline $\begin{array}{l}73-04-05 \\
73-04-05 \\
73-05-23 \\
77-08-02 \\
74-10-22\end{array}$ & $\begin{array}{l}467 \\
450 \\
510 \\
455 \\
355\end{array}$ & $\begin{array}{l}780 \\
740 \\
750 \\
730 \\
836\end{array}$ & $\begin{array}{l}10.0 \\
10.0 \\
12.7 \\
13.0 \\
12.0\end{array}$ & $\begin{array}{l}300 \\
280 \\
290 \\
390 \\
340\end{array}$ & $\begin{array}{r}1.4 \\
1.5 \\
1.2 \\
.4 \\
.2\end{array}$ & $\begin{array}{l}430 \\
420 \\
450 \\
770 \\
610\end{array}$ & $\begin{array}{r}78 \\
74 \\
76 \\
110 \\
92\end{array}$ \\
\hline $\begin{array}{l}74-10-22 \\
77-08-27 \\
80-04-08 \\
80-02-05 \\
77-10-11\end{array}$ & $\begin{array}{l}368 \\
375 \\
901 \\
546 \\
849\end{array}$ & $\begin{array}{r}610 \\
630 \\
1200 \\
740 \\
1100\end{array}$ & $\begin{array}{r}12.0 \\
13.0 \\
10.0 \\
-- \\
10.0\end{array}$ & $\begin{array}{l}340 \\
340 \\
630 \\
250 \\
550\end{array}$ & $\begin{array}{r}.3 \\
.2 \\
.5 \\
\varepsilon 1.6 \\
.7\end{array}$ & $\begin{array}{r}930 \\
670 \\
80 \\
80 \\
2400\end{array}$ & $\begin{array}{r}92 \\
94 \\
180 \\
29 \\
150\end{array}$ \\
\hline $\begin{array}{l}76-04-19 \\
80-02-05 \\
77-05-11 \\
77-05-08 \\
77-06-08\end{array}$ & $\begin{array}{r}397 \\
441 \\
1020 \\
1270 \\
1290\end{array}$ & $\begin{array}{r}640 \\
710 \\
1300 \\
1500 \\
1600\end{array}$ & $\begin{array}{r}11.0 \\
=- \\
=- \\
=\end{array}$ & $\begin{array}{l}340 \\
180 \\
700 \\
780 \\
810\end{array}$ & $\begin{array}{r}.3 \\
2.5 \\
.6 \\
.9 \\
.9\end{array}$ & $\begin{array}{r}540 \\
140 \\
5600 \\
730 \\
2100\end{array}$ & $\begin{array}{l}91 \\
8.9 \\
180 \\
200 \\
210\end{array}$ \\
\hline $\begin{array}{l}80-01-28 \\
74-06-07 \\
74-06-07 \\
77-06-08 \\
73-10-05\end{array}$ & $\begin{array}{l}785 \\
385 \\
340 \\
403 \\
791\end{array}$ & $\begin{array}{r}840 \\
570 \\
520 \\
620 \\
1100\end{array}$ & $\begin{array}{c}9.0 \\
=- \\
=- \\
=-\end{array}$ & $\begin{array}{l}430 \\
310 \\
290 \\
304 \\
510\end{array}$ & $\begin{array}{l}.5 \\
.3 \\
.3 \\
.5 \\
.9\end{array}$ & $\begin{array}{r}8400 \\
50 \\
20 \\
240 \\
760\end{array}$ & $\begin{array}{r}110 \\
83 \\
75 \\
82 \\
140\end{array}$ \\
\hline $\begin{array}{l}00-04-11 \\
77-02-14 \\
\{0-64-07 \\
7=-07-28 \\
77-05-03\end{array}$ & $\begin{array}{r}1370 \\
1200 \\
1220 \\
590 \\
735\end{array}$ & $\begin{array}{l}1700 \\
1500 \\
1500 \\
340 \\
990\end{array}$ & $\begin{array}{l}10.0 \\
10.0 \\
10.0 \\
14.0 \\
-.0\end{array}$ & $\begin{array}{l}760 \\
783 \\
630 \\
406 \\
490\end{array}$ & $\begin{array}{r}2.2 \\
1.2 \\
1.5 \\
.9 \\
.8\end{array}$ & $\begin{array}{r}330 \\
830 \\
110 \\
730 \\
1800\end{array}$ & $\begin{array}{l}200 \\
190 \\
180 \\
100 \\
130\end{array}$ \\
\hline $\begin{array}{l}75-07-28 \\
75-07-28\end{array}$ & $\begin{array}{l}852 \\
835\end{array}$ & $\begin{array}{l}1: 00 \\
1200\end{array}$ & $\begin{array}{r}1.4 \\
14.0\end{array}$ & $\begin{array}{l}530 \\
500\end{array}$ & $\begin{array}{l}1.1 \\
1.0\end{array}$ & $\begin{array}{l}1300 \\
1000\end{array}$ & $\begin{array}{r}140 \\
130\end{array}$ \\
\hline
\end{tabular}


Table 5. Continued

\begin{tabular}{|c|c|c|c|c|c|c|c|c|c|c|c|c|}
\hline $\begin{array}{l}\text { MAGNE- } \\
\text { SIUM, } \\
\text { DIS- } \\
\text { SOLVED } \\
\text { (MGGL } \\
\text { AS MG) }\end{array}$ & $\begin{array}{l}\text { SODIUM, } \\
\text { DIS- } \\
\text { SOLVED } \\
\text { (MG /L } \\
\text { AS NA) }\end{array}$ & $\begin{array}{l}\text { POTAS- } \\
\text { SIUM, } \\
\text { DIS- } \\
\text { SOLVED } \\
\text { (MGIL } \\
\text { AS K) }\end{array}$ & $\begin{array}{l}\text { MANGA- } \\
\text { NESE:- } \\
\text { DIS- } \\
\text { SOLVED } \\
\text { (UG/L } \\
\text { AS MN) }\end{array}$ & $\begin{array}{l}\text { SULFATE } \\
\text { OIS- } \\
\text { SOLVEO } \\
\text { IMG IL } \\
\text { AS SO4: }\end{array}$ & $\begin{array}{l}\text { NITRO- } \\
\text { GEN, } \\
\text { NITRATE } \\
\text { OIS- } \\
\text { SOLVED } \\
\text { (MG/L } \\
\text { AS NO3) }\end{array}$ & $\begin{array}{l}\text { FLUO- } \\
\text { RIDE, } \\
\text { DIS- } \\
\text { SOLVEO } \\
\text { IMG:L } \\
\text { AS FI }\end{array}$ & $\begin{array}{l}\text { CHLO- } \\
\text { RIDE, } \\
\text { DIS- } \\
\text { SOLVED } \\
\text { (MC/L } \\
\text { AS CL, }\end{array}$ & $\begin{array}{c}\text { BICAR- } \\
\text { BONATE } \\
\text { (MG/L } \\
\text { AS } \\
\text { HCO3) }\end{array}$ & $\begin{array}{l}\text { GROSS } \\
\text { ALPHA, } \\
\text { DIS- } \\
\text { SOLVID } \\
\text { (UG/L } \\
\text { AS } \\
U \text { U-NAT) }\end{array}$ & $\begin{array}{l}\text { RADIUM } \\
226, \\
\text { DIS- } \\
\text { SOLYED } \\
\text { (PCI/L) }\end{array}$ & $\begin{array}{c}\text { RADIUM } \\
\text { 22B, } \\
\text { TOTAL } \\
\text { (PCI/L) }\end{array}$ & $\begin{array}{c}\text { GROSS } \\
\text { BETA, } \\
\text { DIS- } \\
\text { SOLVED } \\
\text { CPCI/L } \\
\text { AS } \\
\text { CS-137? }\end{array}$ \\
\hline $\begin{array}{l}56 \\
36 \\
65 \\
67 \\
35\end{array}$ & $\begin{array}{l}62 \\
13 \\
67 \\
68 \\
23\end{array}$ & $\begin{array}{l}20 \\
2.7 \\
6.8 \\
6.4 \\
4.0\end{array}$ & $\begin{array}{r}<10 \\
170 \\
920 \\
100 \\
40\end{array}$ & $\begin{array}{r}300 \\
110 \\
420 \\
470 \\
28\end{array}$ & $\begin{array}{l}<.10 \\
1.3 \\
.40 \\
<.10 \\
.10\end{array}$ & $\begin{array}{r}1.5 \\
.6 \\
.3 \\
.3 \\
.2\end{array}$ & $\begin{array}{r}12 \\
2.0 \\
1.0 \\
1.5 \\
1.0\end{array}$ & $\begin{array}{l}365 \\
395 \\
483 \\
490 \\
533\end{array}$ & $\begin{array}{l}6.7 \\
-.7 \\
7.7 \\
2.0 \\
-.\end{array}$ & $\begin{array}{l}2.2 \\
1.2 \\
-- \\
--\end{array}$ & $\begin{array}{l}-- \\
-- \\
-- \\
--\end{array}$ & $\begin{array}{r}15 \\
5.0 \\
.0 \\
--\end{array}$ \\
\hline $\begin{array}{l}71 \\
27 \\
23 \\
43 \\
20\end{array}$ & $\begin{array}{r}140 \\
18 \\
12 \\
28 \\
14\end{array}$ & $\begin{array}{r}11 \\
2.9 \\
3.9 \\
9.4 \\
5.0\end{array}$ & $\begin{array}{l}470 \\
<10 \\
120 \\
240 \\
170\end{array}$ & $\begin{array}{r}880 \\
76 \\
21 \\
45 \\
52\end{array}$ & $\begin{array}{r}<.10 \\
22.20 \\
.80 \\
.50\end{array}$ & $\begin{array}{l}.9 \\
.5 \\
.4 \\
.4 \\
.3\end{array}$ & $\begin{array}{r}7.5 \\
46.5 \\
1.5 \\
6.0 \\
3.0\end{array}$ & $\begin{array}{l}310 \\
360 \\
365 \\
553 \\
318\end{array}$ & $\begin{array}{r}25 \\
1.5 \\
2.4 \\
2.1 \\
--\end{array}$ & $\begin{array}{c}5.8 \\
-- \\
.4 \\
--\end{array}$ & $\begin{array}{l}-- \\
1.9 \\
--\end{array}$ & $\begin{array}{r}12 \\
3.0 \\
5.0 \\
20 \\
--\end{array}$ \\
\hline $\begin{array}{r}150 \\
120 \\
62 \\
64 \\
61\end{array}$ & $\begin{array}{l}210 \\
200 \\
100 \\
96 \\
130\end{array}$ & $\begin{array}{l}11 \\
9.5 \\
9.1 \\
14 \\
12\end{array}$ & $\begin{array}{r}2400 \\
2800 \\
950 \\
150 \\
130\end{array}$ & $\begin{array}{r}1500 \\
1300 \\
630 \\
750 \\
730\end{array}$ & $\begin{array}{l}2.0 \\
1.9 \\
<.10 \\
<.10 \\
<.10\end{array}$ & $\begin{array}{r}.4 \\
.4 \\
.9 \\
.9 \\
1.2\end{array}$ & $\begin{array}{l}12 \\
<.5 \\
5.0 \\
6.5 \\
9.0\end{array}$ & $\begin{array}{l}334 \\
372 \\
398 \\
349 \\
357\end{array}$ & $\begin{array}{l}10^{.0} \\
26 \\
13 \\
8.5\end{array}$ & $\begin{array}{r}-. \\
2.3 \\
7.3 \\
15 \\
-.\end{array}$ & $\begin{array}{l}=- \\
-- \\
-- \\
--\end{array}$ & $\begin{array}{l}33 \\
23 \\
25 \\
40 \\
29\end{array}$ \\
\hline $\begin{array}{l}18 \\
21 \\
51 \\
41 \\
41\end{array}$ & $\begin{array}{l}14 \\
12 \\
62 \\
58 \\
48\end{array}$ & $\begin{array}{l}4.4 \\
4.3 \\
12 \\
11 \\
11\end{array}$ & $\begin{array}{l}190 \\
190 \\
280 \\
110 \\
260\end{array}$ & $\begin{array}{r}54 \\
65 \\
260 \\
250 \\
290\end{array}$ & $\begin{array}{l}.30 \\
<.10 \\
<.10 \\
.40 \\
.20\end{array}$ & $\begin{array}{l}.3 \\
.4 \\
.2 \\
.5 \\
.4\end{array}$ & $\begin{array}{l}2.0 \\
2.0 \\
90 \\
58 \\
14\end{array}$ & $\begin{array}{l}324 \\
338 \\
405 \\
344 \\
359\end{array}$ & $\begin{array}{r}-- \\
4.3 \\
5.1 \\
11 \\
8.3\end{array}$ & $\begin{array}{l}-. \\
1.9 \\
5.0 \\
3.3 \\
5.3\end{array}$ & $\begin{array}{r}2.5 \\
\square- \\
--\end{array}$ & $\begin{array}{l}12^{--} \\
25 \\
19^{--} \\
15\end{array}$ \\
\hline $\begin{array}{l}34 \\
44 \\
50 \\
29 \\
29\end{array}$ & $\begin{array}{l}53 \\
48 \\
43 \\
56 \\
48\end{array}$ & $\begin{array}{l}9.8 \\
12 \\
11 \\
7.1 \\
6.9\end{array}$ & $\begin{array}{r}150 \\
220 \\
90 \\
240 \\
2 \leq 0\end{array}$ & $\begin{array}{l}230 \\
160 \\
200 \\
200 \\
22\end{array}$ & $\begin{array}{r}.50 \\
.20 \\
3.6 \\
<.10 \\
<.10\end{array}$ & $\begin{array}{l}.3 \\
.3 \\
.2 \\
.4 \\
.3\end{array}$ & $\begin{array}{l}13 \\
73 \\
49 \\
29 \\
11\end{array}$ & $\begin{array}{l}332 \\
432 \\
468 \\
307 \\
261\end{array}$ & $\overline{11}^{3.5}$ & $\begin{array}{r}2.3 \\
2.7 \\
-- \\
--\end{array}$ & $\begin{array}{l}-- \\
-- \\
=- \\
--\end{array}$ & $16^{23}-$ \\
\hline $\begin{array}{l}26 \\
22 \\
24 \\
27 \\
26\end{array}$ & $\begin{array}{l}56 \\
56 \\
48 \\
16 \\
10\end{array}$ & $\begin{array}{l}6.6 \\
5.3 \\
0.9 \\
5.3 \\
5.5\end{array}$ & $\begin{array}{l}470 \\
250 \\
240 \\
110 \\
110\end{array}$ & $\begin{array}{r}210 \\
210 \\
210 \\
74 \\
31\end{array}$ & $\begin{array}{l}<.10 \\
<.10 \\
<.10 \\
.20 \\
.10\end{array}$ & $\begin{array}{l}.4 \\
.5 \\
.4 \\
.5 \\
.3\end{array}$ & $\begin{array}{r}17 \\
19 \\
9.0 \\
3.5 \\
<.5\end{array}$ & $\begin{array}{l}246 \\
2: 0 \\
227 \\
390 \\
386\end{array}$ & $\begin{array}{r}-- \\
-- \\
17 \\
8.2\end{array}$ & $10^{--}$ & $\begin{array}{l}-- \\
-- \\
-- \\
--\end{array}$ & $16^{--}$ \\
\hline $\begin{array}{l}26 \\
26 \\
44 \\
42 \\
42\end{array}$ & $\begin{array}{l}11 \\
8.9 \\
30 \\
60 \\
29\end{array}$ & $\begin{array}{l}6.0 \\
7.0 \\
3.6 \\
7.2 \\
8.3\end{array}$ & $\begin{array}{r}110 \\
170 \\
200 \\
40 \\
160\end{array}$ & $\begin{array}{r}28 \\
18 \\
400 \\
280 \\
310\end{array}$ & $\begin{array}{r}.20 \\
.40 \\
<.10 \\
.40 \\
.10\end{array}$ & $\begin{array}{l}.4 \\
.4 \\
.3 \\
.3 \\
.7\end{array}$ & $\begin{array}{l}<.5 \\
2.0 \\
2.0 \\
2.0 \\
1.5\end{array}$ & $\begin{array}{r}392 \\
398 \\
377 \\
88 \\
350\end{array}$ & $\begin{array}{r}8.4 \\
4.4 \\
-.0 \\
3.8\end{array}$ & $\begin{array}{r}5.1 \\
3.4 \\
--. \\
1.8\end{array}$ & $\begin{array}{l}=- \\
=- \\
=- \\
=-\end{array}$ & $\begin{array}{r}17 \\
12 \\
7.5 \\
3.0\end{array}$ \\
\hline $\begin{array}{l}28 \\
37 \\
51 \\
53 \\
69\end{array}$ & $\begin{array}{l}11 \\
60 \\
29 \\
55 \\
58\end{array}$ & $\begin{array}{r}3.3 \\
8.9 \\
7.5 \\
9.0 \\
10\end{array}$ & $\begin{array}{r}120 \\
50 \\
170 \\
9=0 \\
730\end{array}$ & $\begin{array}{r}84 \\
160 \\
370 \\
500 \\
560\end{array}$ & $\begin{array}{l}.20 \\
.20 \\
.10 \\
.20 \\
.20\end{array}$ & $\begin{array}{l}.5 \\
.2 \\
.2 \\
.8 \\
.6\end{array}$ & $\begin{array}{r}19^{.5} \\
.5 \\
1.5 \\
1.0\end{array}$ & $\begin{array}{l}332 \\
154 \\
503 \\
400 \\
468\end{array}$ & $\begin{array}{r}-. \\
.6 \\
2.9 \\
.8 \\
1.8\end{array}$ & $\begin{array}{l}-- \\
-- \\
-- \\
--\end{array}$ & $\begin{array}{l}-- \\
-- \\
-- \\
--\end{array}$ & $\begin{array}{r}7.0 \\
10 \\
5.0 \\
7.0\end{array}$ \\
\hline $\begin{array}{l}37 \\
25 \\
23 \\
=4 \\
40\end{array}$ & $\begin{array}{l}25 \\
13 \\
9.9 \\
: 9 \\
26\end{array}$ & $\begin{array}{l}4.4 \\
2.0 \\
2.1 \\
2.5 \\
6.5\end{array}$ & $\begin{array}{r}480 \\
110 \\
70 \\
<10 \\
260\end{array}$ & $\begin{array}{r}150 \\
41 \\
23 \\
63 \\
290\end{array}$ & $\begin{array}{r}.20 \\
.50 \\
5.10 \\
1.20 \\
<.10\end{array}$ & $\begin{array}{l}1 \\
2 \\
2 \\
2 \\
7\end{array}$ & $\begin{array}{l}6.0 \\
.5 \\
<.5 \\
6.5 \\
3.0\end{array}$ & $\begin{array}{l}366 \\
338 \\
322 \\
337 \\
378\end{array}$ & $\begin{array}{l}6.9 \\
2.2 \\
1.6 \\
1.6 \\
-.\end{array}$ & $\begin{array}{l}1.1 \\
-- \\
-- \\
--\end{array}$ & $\begin{array}{c}1.0 \\
=- \\
-- \\
--\end{array}$ & $\begin{array}{l}10 \\
6.0 \\
6.0 \\
2 . \therefore \\
-\end{array}$ \\
\hline $\begin{array}{l}63 \\
74 \\
50 \\
34 \\
33\end{array}$ & $\begin{array}{l}1 \leq 0 \\
76 \\
32 \\
12 \\
40\end{array}$ & $\begin{array}{r}14 \\
5.1 \\
8.2 \\
5.4 \\
7.0\end{array}$ & $\begin{array}{r}120 \\
1300 \\
1600 \\
150 \\
200\end{array}$ & $\begin{array}{l}730 \\
470 \\
560 \\
190 \\
260\end{array}$ & $\begin{array}{r}.10 \\
.10 \\
.20 \\
.10 \\
<.10\end{array}$ & $\begin{array}{r}1.2 \\
.3 \\
.4 \\
.6 \\
.6\end{array}$ & $\begin{array}{l}9.0 \\
1.0 \\
7.0 \\
2.0 \\
2.5\end{array}$ & $\begin{array}{l}370 \\
503 \\
390 \\
350 \\
36 !\end{array}$ & $\begin{array}{l}12.5 \\
2.5 \\
15\end{array}$ & $\begin{array}{r}1.3 \\
1.3 \\
-- \\
-- \\
2.7\end{array}$ & $\begin{array}{c}5.5 \\
-- \\
-- \\
-- \\
--\end{array}$ & $\begin{array}{l}30 \\
19 \\
11 \\
14\end{array}$ \\
\hline $\begin{array}{l}44 \\
43\end{array}$ & $\begin{array}{l}58 \\
53\end{array}$ & $\begin{array}{l}6.8 \\
6.8\end{array}$ & $\begin{array}{l}250 \\
210\end{array}$ & $\begin{array}{l}330 \\
290\end{array}$ & $\begin{array}{l}.30 \\
.00\end{array}$ & .7 & $\begin{array}{l}6.0 \\
4.0\end{array}$ & $\begin{array}{l}370 \\
362\end{array}$ & $\begin{array}{l}7.2 \\
6.5\end{array}$ & $\begin{array}{l}2.8 \\
2.7\end{array}$ & -- & $\begin{array}{l}18 \\
14\end{array}$ \\
\hline
\end{tabular}

